\title{
20. LATE CRETACEOUS DINOFLAGELLATE CYSTS (?SANTONIAN-MAESTRICHTIAN) FROM THE SOUTHERN INDIAN OCEAN (HOLE 748C) ${ }^{1}$
}

\author{
Shaozhi $\mathrm{Mao}^{2}$ and Barbara A.R. Mohr ${ }^{3}$
}

\begin{abstract}
At Ocean Drilling Program Hole $748 \mathrm{C}$ in the Southern Indian Ocean, a total of 171 Late Cretaceous dinoflagellate taxa were encountered in 38 productive samples from Cores $120-748 \mathrm{C}-27 \mathrm{R}$ through $120-748 \mathrm{C}-62 \mathrm{R}$ ( $407-740 \mathrm{mbsf}$ ). Four provisional dinoflagellate assemblage zones and five subzones were recognized based on the character of the dinoflagellate flora and the first/last occurrences of some key species. Isabelidinium korojonense and Nelsoniella aceras occur in Zone A together with Oligosphaeridium pulcherrimum and Trithyrodinium suspectum. Zone B was delineated by the total range of Odontochitina cribropoda. Zone C was separated from Zone B by the presence of Satyrodinium haumuriense, and Zone D is dominated by new taxa. The dinocyst assemblages bear a strong affinity to Australian assemblages. Paleoenvironmental interpretations based mainly on dinocysts suggest that during the ?Santonian-Campanian to the Maestrichtian this portion of the Kerguelen Plateau was a shallow submerged plateau, similar to nearshore to offshore to upper slope environments with water depths of tens to hundreds of meters, but isolated from the major continents of the Southern Hemisphere. Starting perhaps in the late Cenomanian (Mohr and Gee, this volume), the Late Cretaceous transgression over the plateau reached its maximum during the late Campanian. The plateau may have been exposed above sea level and subjected to weathering during the latest Maestrichtian. The studied dinocyst assemblages characterized by species of Amphidiadema, Nelsoniella, Satyrodinium, and Xenikoon together with abundant Chatangiella (the large-size species) and Isabelidinium suggest that a South Indian Province (tentatively named the Helby suite) may have existed during the Campanian-Maestrichtian in comparison with the other four provinces of Lentin and Williams. One new genus, three new species, and two new subspecies of dinocysts are described.
\end{abstract}

\section{INTRODUCTION}

Ocean Drilling Program (ODP) Site 748 is located on the Southern Kerguelen Plateau $\left(58^{\circ} 26.45^{\prime} \mathrm{S}, 78^{\circ} 58.89^{\prime} \mathrm{E}\right)$ (Fig. 1) in a water depth of $1290 \mathrm{~m}$. The objective at Site 748 was to recover an expanded section of Cretaceous and Paleogene sediments to decipher the tectonic and geologic history of this part of the plateau. To achieve this goal, it is necessary to date the seismic stratigraphic section precisely by paleontologic methods. Equally important is reconstruction of the environments under which the sediments formed. Dinoflagellates have proven useful in biostratigraphy and paleoenvironmental reconstruction because of their planktonic habit and their preservable organic-walled (some with calcareous or siliceous walls) cysts.

Late Cretaceous dinoflagellates from the Southern Hemisphere, especially from Australia, have been studied for almost half a century, in particular by the late Isabel Cookson, often in association with coworkers (Cookson, 1956; Cookson and Eisenack, 1958, 1960a, 1960b, 1961, 1962, 1971, 1974, 1982; Manum and Cookson, 1964). These previous studies, however, were chiefly concerned with systematic descriptions, and the various zonation schemes proposed by several authors (Edgell, 1964; Evans, 1966; Morgan, 1977; among others) are based mainly on data from wells in different basins. Not until the mid-1980s was a more complete zonation scheme given by Wilson (1984) for New Zealand and by Helby et al. (1987) for Australia. These zonation schemes have provided

\footnotetext{
${ }^{1}$ Wise, S. W., Jr., Schlich, R., et al., 1992. Proc. ODP, Sci. Results, 120: College Station, TX (Ocean Drilling Program).

2 Graduate School, China University of Geosciences, Beijing 100083, China (current address: Department of Geology, Florida State University, Tallahassee, FL 32306, U.S.A.).

${ }^{3}$ ETH-Zürich, Geological Institute, 8092 Zürich, Switzerland.
}

palynologists with important criteria for stratigraphic correlation. Site 748 provides a unique, nearly continuous section of Cenomanian-Maestrichtian sediments that contains nannofossils and foraminifers as well as palynomorphs. The dating of the section is, therefore, more precise, as it is based on well-documented multidisciplinary calcareous microfossil chronostratigraphy. As a result, this study will add more information to what is already known about dating and correlating dinoflagellate zones in this region and should enhance the value of the zonation schemes proposed by Wilson (1984) and Helby et al. (1987).

The sediments from Hole $748 \mathrm{C}$ were divided into four units (Schlich, Wise, et al., 1989). A detailed description of the upper two lithologic units ranging from Pleistocene through Paleocene (Cores 120-748C-1R through 120-748C26R), the basal unit, and the basal two subunits of Unit III ranging from Cenomanian to Santonian (Core 120-748C-78R through Section 120-748C-62R-CC) is found in Schlich, Wise, et al., 1989). Samples for the present study are from the upper two Subunits IIIB and IIIA of ?Santonian through Maestrichtian age (from 407 to $740 \mathrm{~m}$ below seafloor (mbsf); Core 120-748C-27R through Section 120-748C-62R-4). They consist of glauconitic rudstones, packstones, and grainstones, intermittently silicified, with intervals of abundant bryozoans, inoceramid prisms, and crinoid columnals and rare red algal debris (Fig. 2).

\section{MATERIALS AND METHODS}

The samples studied from Core $120-748 \mathrm{C}-27 \mathrm{R}$ through Section 120-748C-62R-4 are mainly glauconitic sandstones, siltstones, and claystones. One or two samples were processed from each core, and about the same volume of rock was used for each processed sample. Samples were processed using standard maceration and centrifuge preparation tech- 


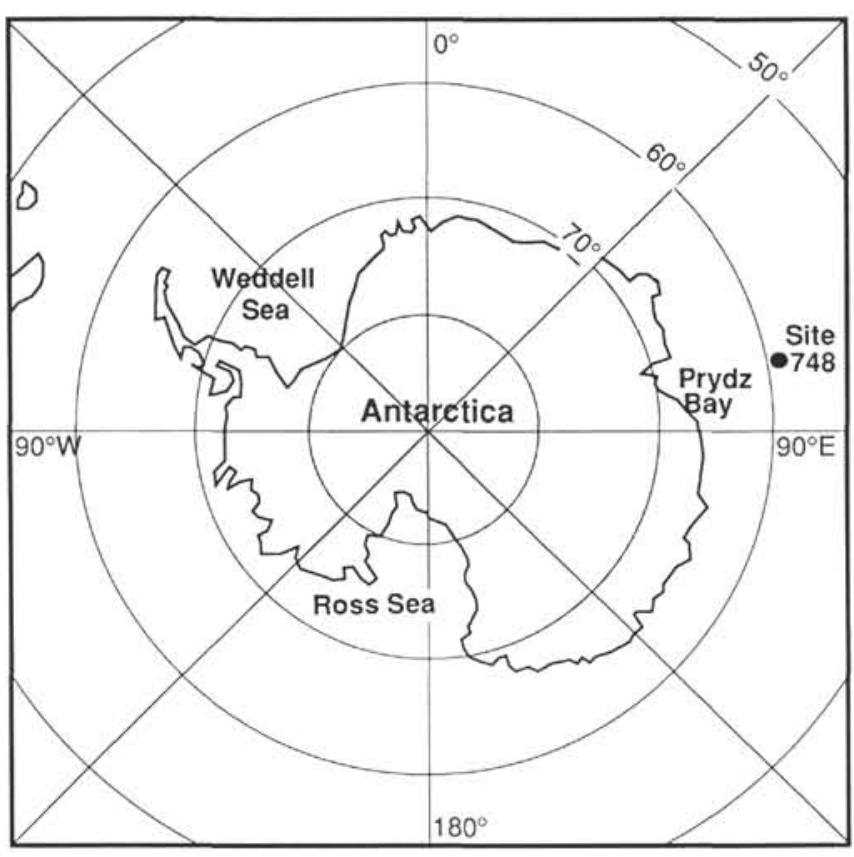

Figure 1. Location of Site 748 study area (simplified from Wei, this volume).

niques for palynomorphs, in addition to screening with a $15-\mu \mathrm{m}$ mesh sieve. The microscopic observation and counting of each sample were carried out on two slides (each with one $20 \times 40 \mathrm{~mm}$ cover slide). For taxonomic determinations and photographic documentation, additional single-specimen mounts were made. ODP localities and slide numbers of the holotype specimens are given in the plate captions.

The U.S. National Museum, Washington, D.C., is the curator of all slides with type specimens.

\section{RESULTS}

\section{Dinoflagellate Stratigraphy and Age}

\section{General Aspects}

One hundred and seventy-one taxa of dinoflagellate cysts were recovered from the studied section (Table 1), of which most have been recorded previously from the Southern Hemisphere. The general preservation of the dinocysts is moderate, but it varies from good to poor in different intervals. In addition to the abundant and diverse dinoflagellates, a small number of acritarchs (such as Palambags morulosa, Pterospermella australiensis, and Veryhachium sp.) and rare pollen and spores were recovered (such as Nothofagidites sp. and Proteacidites sp.) (Plate 5, Figs. 11 and 14-16; Plate 6, Fig. 9).

\section{Zonation and Age}

The geological ranges of dinocyst species, like those of some other fossils, vary geographically; they are controlled apparently by a variety of factors, such as facies, sedimentation rates, local discontinuities, etc., and are not as well known as those of nannofossils. Certain species, however, do have consistent ranges that can be used for stratigraphic correlation and age determination. The dinocyst taxonomy used here generally follows the index of Lentin and Williams (1989). The index contains the full citations to the original papers used in the present paper. These citations, therefore, will not be repeated in the references. A complete list of all taxa encountered in our material is given in Appendix A. The geological ranges of selected dinocyst species compiled from data by Harker and Sarjeant (1975), Williams and Bujak (1985), and Helby et al. (1987) as well as some individual papers are given in Appendix B.

The four provisional dinoflagellate assemblage zones here proposed and defined in ascending stratigraphic order are based on the content of dinoflagellate flora and the first/last occurrence (FO/LO) of certain species recorded in Hole $748 \mathrm{C}$ (Table 1 and Fig. 3).

Dinocyst Zone A (Sections 120-748C-62R-4 through 120$748 C-62 R-1$, approximately $740-732 \mathrm{mbsf}$ )

Zone A is characterized by the co-occurrence of Chatangiella tripartita, Chlamydophorella discreta, Isabelidinium korojonense, I. microarmum, Nelsoniella aceras, Palaeohystrichophora infusorioides, and Trithyrodinium suspectum as well as the acme species Oligosphaeridium pulcherrimum. The species diversity in the zone is as low as 27 taxa.

Isabelidinium microarmum was described from the Campanian-Maestrichtian of arctic Canada (McIntyre, 1975). Chatangiella tripartita (Cookson and Eisenack, 1960a), C. victoriensis (Manum and Cookson, 1964), and Isabelidinium belfastense (Cookson and Eisenack, 1961) were described from the undifferentiated Senonian of Australia, as were Callaiosphaeridium asymmetricum (Deflandre and Courteville, 1939), Chatangiella spectabilis, and Isabelidinium cooksoniae (upper Senonian; Alberti, 1959) from Europe. In North America, Chatangiella tripartita together with Circulodinium distinctum and Odontochitina spp. was found in Campanian sediments (Roberts, 1980, unpubl. data). These species have longer ranges on a global scale than at the localities where they were described (Fig. 4). The known ranges of the 13 species in Zone A shown in Figure 4 suggest a more reasonable age assignment of Campanian to early Maestrichtian for the zone. However, it is more likely that Zone $\mathrm{A}$ is early Campanian or possibly Santonian to early Campanian in age in comparison to the nannofossil data (Watkins, this volume; Fig. 5) and the age of the underlying interval (Mohr and Gee, this volume). Comparison with other dinoflagellate zonations for the Late Cretaceous does not provide a more definite answer. The top of Zone A was delineated tentatively at Section $120-748 \mathrm{C}-62 \mathrm{R}-1$ because of a sampling gap between Section 120-748C-62R-1 and Core 120-748C-56R.

Dinocyst Zone B (Sections 120-748C-56R-I through 120-748C$38 R-1$, approximately $692-512 \mathrm{mbsf}$ )

Zone B is delineated by the total range of Odontochitina cribropoda with the FO of Spinidinium? clavus at its base in Hole $748 \mathrm{C}$ (Fig. 3). This zone contains the most abundant and diversified assemblage among the four zones and includes 146 taxa (Tables 1 and 2).

Circulodinium distinctum, C. distinctum subsp. longispinatum, Odontochitina cribropoda, and Nelsoniella aceras (in the upper part of the zone) are the most abundant taxa, dominating some assemblages and occurring continuously throughout Zone B. Areoligera sp. cf. A. senonensis, Heterosphaeridium? heteracanthum, $H$. conjunctum, Nelsoniella tuberculata, and Odontochitina porifera have their FOs within the zone. Together with Trithyrodinium suspectum these species are common in Zone B. Species of Chatangiella are most diverse in this zone in comparison with the other three zones. In addition to $C$. tripartita and $C$. victoriensis, C. ? biapertura, $C$. ditissima, $C$. granulifera, $C$. serratula, $C$. spectabilis, and $C$. verrucosa occur within Zone B. Xenikoon australis has its FO near the top of the zone.

Zone $\mathrm{B}$ can be divided into three abundance acme subzones: 


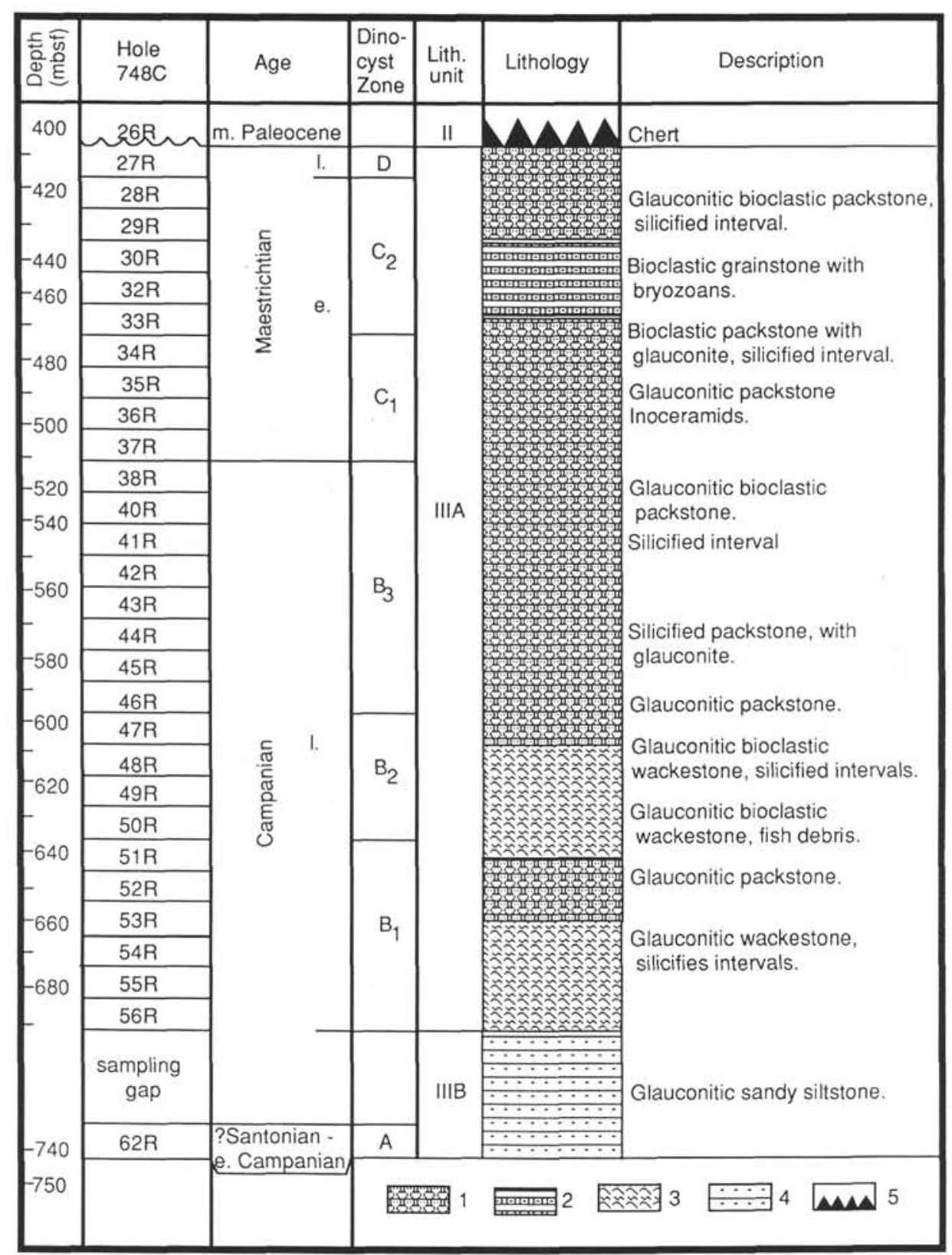

Figure 2. Lithology of the study section. Lithologic patterns: $1=$ packstone, $2=$ grainstone, $3=$ wackestone, $4=$ sandy siltstone, and $5=$ chert (simplified from Schlich, Wise, et al., 1989).

Subzone B-1 (Cores 120-748C-56R through 120-748C-50R, approximately $692-626 \mathrm{mbsf}$ ) is characterized by the acme of Chatangiella tripartita. $C$. ditissima, $C$. granulifera, and $C$. spectabilis are limited to this subzone.

Subzone B-2 (Cores 120-748C-49R through 120-748C-47R, approximately $626-587 \mathrm{mbsf}$ ) is defined at its base by the FO of Isabelidinium cretaceum oviforme n. subsp. and characterized by the acme of the same subspecies.

Subzone B-3 (Cores 120-748C-46R through 120-748C-38R, approximately $587-512 \mathrm{mbsf}$ ) is characterized by the acme of Nelsoniella aceras. Nelsoniella tuberculata is abundant in the upper part of the subzone. Isabelidinium sp. A and Xenikoon australis have their FOs within the subzone.

Figure 6 shows the ranges of 17 species that have their FOs within Zone B. A Campanian age for Zone B is suggested based on the co-occurrence of these species, and a late Campanian assignment for Zone B is in better agreement with the age from nannofossils (Watkins, this volume; Fig. 5).

Dinocyst Zone C (Cores 120-748C-37R through 120-748C-28R, approximately $512-418 \mathrm{mbsf}$ )

Zone $\mathrm{C}$ is defined by the total range of Satyrodinium haumuriense with the LO of Xenikoon australis at its top and the FO of Elytrocysta druggii at the bottom (Fig. 3). Alterbidinium acutulum and Cerodinium diebelii also occur Zone C. Other diagnostic species are Fromea chytra, Isabelidinium pellucidum, and I. sp. A. Odontochitina porifera, Satyrodinium bengalense, Trithyrodinium fragile, and Xenascus ceratioides are also present in the zone. Dinocyst specimen abundance decreases dramatically and species diversity also decreases to 104 taxa in Zone C (Table 1). 
Table 1. Dinoflagellate range chart.

\begin{tabular}{|c|c|c|c|c|c|c|c|c|c|c|c|c|c|c|c|c|c|c|c|c|c|c|c|c|c|c|c|c|}
\hline 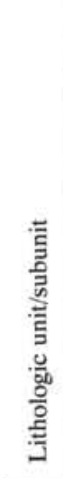 & 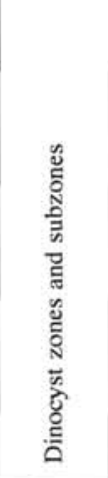 & ge & $\begin{array}{l}\text { Core, section, } \\
\text { interval }(\mathrm{cm})\end{array}$ & 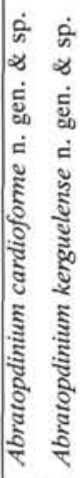 & 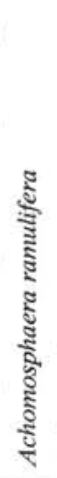 & & 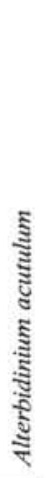 & \multicolumn{2}{|c|}{ 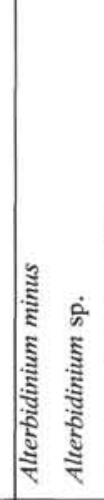 } & 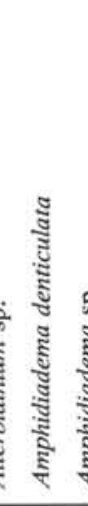 & \multicolumn{2}{|c|}{ 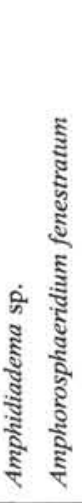 } & 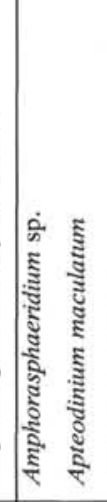 & 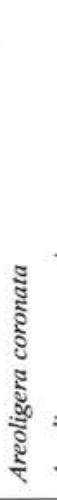 & \multicolumn{2}{|c|}{ 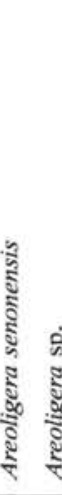 } & 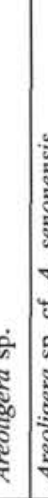 & 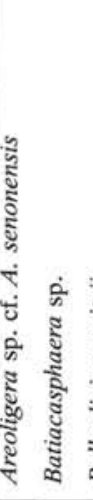 & \multicolumn{3}{|c|}{ 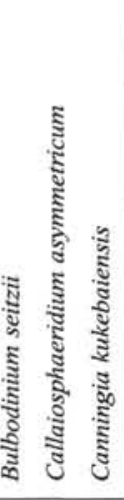 } & \multicolumn{2}{|c|}{ 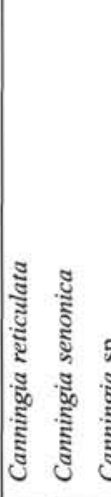 } & \multicolumn{3}{|c|}{ 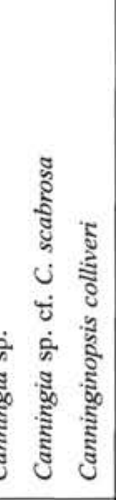 } & \multicolumn{2}{|c|}{ 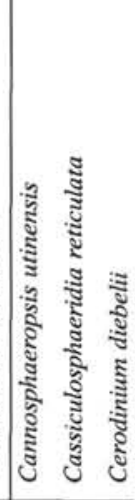 } \\
\hline \multirow{6}{*}{ IIIA } & D & 1. & -14 & . & . & - & & - & . & $\mathrm{P}$ & . & 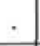 & & & . & & & . & . & . & & S & . & . & . & $\cdot$ & - & \\
\hline & $C_{2}$ & 氖 & & $\begin{array}{ll}\cdot & \\
\vdots & \vdots \\
\vdots & \vdots \\
\vdots & \vdots \\
\end{array}$ & $\vdots$ & : & $\begin{array}{l}\dot{\mathrm{P}} \\
\dot{ } \\
\dot{ }\end{array}$ & $\begin{array}{l}: \\
\dot{\mathrm{R}} \\
\dot{ }\end{array}$ & $\begin{array}{l}\dot{ } \\
\dot{\mathrm{R}} \\
\dot{ }\end{array}$ & $\begin{array}{l}: \\
: \\
:\end{array}$ & $\begin{array}{l}\text { P } \\
\dot{5} \\
\vdots \\
\dot{ }\end{array}$ & $\begin{array}{l}\cdot \\
\dot{.} \\
\dot{.} \\
\dot{.} \\
\end{array}$ & : & * & : & $\begin{array}{l}\dot{\mathrm{R}} \\
\dot{\dot{\mathrm{n}}} \\
\dot{\dot{y}}\end{array}$ & $\dot{.}$ & $\begin{array}{l}: \\
\dot{R}\end{array}$ & $\begin{array}{l}\dot{.} \\
\dot{.} \\
\dot{ }\end{array}$ & : & $\begin{array}{l}: \\
: \\
:\end{array}$ & $\dot{.}$. & $\begin{array}{l}\dot{\mathrm{F}} \\
\dot{\cdot} \\
\dot{ }\end{array}$ & $\begin{array}{l}\dot{\mathrm{R}} \\
\dot{.} \\
\dot{.}\end{array}$ & $\begin{array}{l}: \\
: \\
: \\
.\end{array}$ & & 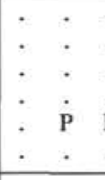 & \\
\hline & C & & & $\begin{array}{ll} & \\
\mathrm{P} & \mathrm{R} \\
\mathrm{F} & \mathrm{F} \\
& \\
\end{array}$ & : & : & : & $\begin{array}{l}\dot{2} \\
\dot{R} \\
\mathrm{P} \\
\dot{ }\end{array}$ & : & : & $:{ }^{i}$ & $:$ & & 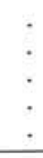 & : & $:$ & $\mathrm{P}$ & $\begin{array}{l}\mathrm{P} \\
\mathrm{R} \\
\dot{\mathrm{P}} \\
\dot{\mathrm{P}}\end{array}$ & : & $:$ & : & $:$ & $:$ & $\dot{\text { P }}$ & $: \quad$ & $\begin{array}{l}\dot{ } \\
\dot{R} \\
\mathrm{P} \\
\mathrm{P}\end{array}$ & $\begin{array}{ll} & \\
\dot{\mathrm{P}} & \\
\mathrm{P} & \\
. & : \\
\end{array}$ & \\
\hline & B & & $\begin{array}{l}20-23 \\
, 67-69 \\
20-23 \\
20-22 \\
60-63 \\
67-69 \\
126-128 \\
112-115 \\
86-89 \\
\end{array}$ & $\begin{array}{ll}\mathrm{R} & \mathrm{F} \\
\mathrm{C} & \mathrm{C} \\
\mathrm{P} & \mathrm{R} \\
: & \vdots \\
\vdots & \vdots \\
\vdots & \vdots \\
\vdots & \vdots \\
& . \\
\end{array}$ & $\therefore$ & $\begin{array}{l}: \\
: \\
: \\
:\end{array}$ & $\begin{array}{l}: \\
: \\
:\end{array}$ & $:$ & $\begin{array}{l}: \\
: \\
: \\
: \\
:\end{array}$ & $\begin{array}{l}\dot{ } \\
\dot{ } \\
\dot{ } \\
\dot{\mathrm{P}} \\
\dot{\mathrm{P}}\end{array}$ & $\begin{array}{l}: \\
: \\
\vdots \\
\vdots \\
:\end{array}$ & $\begin{array}{l}\dot{5} \\
\dot{5} \\
\dot{5}\end{array}$ & . & : & $\begin{array}{l}\dot{2} \\
\dot{\mathrm{R}} \\
\dot{\mathrm{V}} \\
\dot{\mathrm{V}} \\
\dot{.}\end{array}$ & $\begin{array}{l}\dot{.} \\
\dot{\mathrm{C}} \\
\dot{.} \\
\dot{\mathrm{R}} \\
\dot{\mathrm{R}} \\
\dot{ }\end{array}$ & $\begin{array}{l}\text { F } \\
\text { F } \\
\text { F } \\
F \\
\text {. } \\
\end{array}$ & $\begin{array}{l}: \\
\therefore \\
\dot{\mathrm{R}} \\
\dot{\mathrm{R}}\end{array}$ & $\begin{array}{l}: \\
: \\
:\end{array}$ & $\begin{array}{l}: \\
: \\
: \\
: \\
.\end{array}$ & $\begin{array}{l}: \\
: \\
: \\
: \\
:\end{array}$ & $\begin{array}{l}\dot{.} \\
\dot{\mathrm{R}} \\
\dot{\mathrm{P}} \\
\dot{\mathrm{P}} \\
\dot{ }\end{array}$ & $\begin{array}{l}: \\
\dot{ } \\
\dot{5} \\
\dot{\mathrm{F}}\end{array}$ & $\begin{array}{l}\dot{ } \\
\dot{ } \\
\dot{\mathrm{P}} \\
\dot{\mathrm{P}} \\
\dot{ } \\
\end{array}$ & 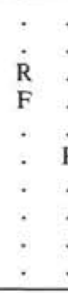 & 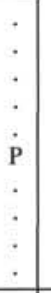 & 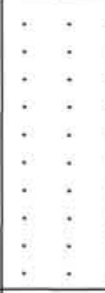 & \\
\hline & B & 岂 & $9 \mathrm{k}-1,80-82$ & $\begin{array}{ll}. & \mathrm{P} \\
: & : \\
& \\
\end{array}$ & $:$ & i. & $:$ & $:$ & $\dot{.} \cdot$ & $\begin{array}{l}\mathrm{P} \\
\dot{\mathrm{A}} \\
\mathrm{F}\end{array}$ & $\dot{\mathrm{R}}$ & . &. & $\cdot$ & : & : & \begin{tabular}{|l}
$\mathrm{R}$ \\
$\dot{\mathrm{A}}$ \\
$\mathrm{F}$ \\
\end{tabular} & $\dot{\mathrm{P}}$ & $\begin{array}{l}P \\
. \\
.\end{array}$ & $\dot{.}$ & : & $\begin{array}{l}P \\
: \\
\end{array}$ & $\begin{array}{l}P \\
\dot{.} \\
\dot{.}\end{array}$ & $\dot{.}$ & : & $:$ & $\begin{array}{ll}\cdot & \cdot \\
\cdot & . \\
\cdot & . \\
\cdot & \end{array}$ & \\
\hline & $B_{1}$ & & $\begin{array}{l}0 \mathrm{R}-1,50-52 \\
1 \mathrm{R}-1,105-108 \\
2 \mathrm{R}-1,45-47 \\
3 \mathrm{R}-1,55-58 \\
4 \mathrm{R}-1,146-148 \\
4 \mathrm{R}-\mathrm{CC} \\
5 \mathrm{R}-1,42-45 \\
5 \mathrm{R}-2,125-129 \\
6 \mathrm{R}-1,77-79 \\
\end{array}$ & $\begin{array}{ll}: & : \\
: & : \\
: & : \\
: & : \\
: & : \\
& : \\
\end{array}$ & $\begin{array}{l}\dot{ } \\
\dot{\mathrm{R}} \\
\dot{ } \\
\dot{ }\end{array}$ & $\begin{array}{l}: \\
: \\
: \\
\text { R }\end{array}$ & : & $\begin{array}{l}: \\
: \\
: \\
\dot{\mathrm{P}} \\
\dot{ }\end{array}$ & $\begin{array}{l}: \\
\dot{\mathrm{F}} \\
\dot{ } \\
\dot{ }\end{array}$ & $\begin{array}{l}\mathrm{F} \\
\dot{ } \\
\dot{\mathrm{P}} \\
\dot{ }\end{array}$ & $:$ & . & : & : & $\begin{array}{l}\mathrm{P} \\
\mathrm{P} \\
\dot{ } \\
\dot{\mathrm{P}} \\
\dot{\mathrm{P}} \\
\dot{ }\end{array}$ & $\begin{array}{l}\dot{.} \\
\dot{5} \\
\dot{\mathrm{R}} \\
\dot{ }\end{array}$ & $\begin{array}{l}\mathrm{R} \\
\dot{ } \\
\dot{\mathrm{V}} \\
\dot{\mathrm{V}} \\
\dot{\mathrm{P}} \\
\mathrm{P}\end{array}$ & $\therefore$ & $\begin{array}{l}: \\
: \\
\dot{\mathrm{P}} \\
\dot{\mathrm{P}}\end{array}$ & $:$ & $\begin{array}{l}\dot{\mathrm{P}} \\
: \\
\dot{ } \\
: \\
\end{array}$ & $\begin{array}{l}\mathrm{F} \\
\dot{\mathrm{F}} \\
\dot{ } \\
\dot{\mathrm{P}} \\
\dot{\mathrm{P}} \\
\end{array}$ & $\begin{array}{l}\dot{\mathrm{P}} \\
\dot{\mathrm{A}} \\
\dot{ } \\
\dot{ }\end{array}$ & $\begin{array}{l}\text { : } \\
: \\
\text { P }\end{array}$ & $\begin{array}{ll} & 1 \\
: & 1 \\
: & \\
: & \\
: & \\
\end{array}$ & $\begin{array}{l}\mathrm{P} \\
\mathrm{R} \\
\vdots \\
\vdots \\
\vdots \\
\vdots\end{array}$ & $\begin{array}{ll}. & : \\
: & : \\
: & : \\
: & : \\
: & : \\
. & : \\
\end{array}$ & \\
\hline m & A & Campan. & & : $:$ & . & : & . & . & . & : & . & . & & & : & . & . & : & $\begin{array}{l}\mathrm{R} \\
\text {. }\end{array}$ & $\dot{\mathrm{R}}$ &. & $\begin{array}{l}\mathrm{F} \\
\mathrm{P}\end{array}$ & : & : & $\therefore$ & $\begin{array}{l}\mathrm{P} \\
\text {. }\end{array}$ & . $\quad$. & \\
\hline
\end{tabular}

Zone $\mathrm{C}$ can be divided into two subzones on the basis of the acmes of certain species:

Subzone C-1 (Cores 120-748C-37R through 120-748C-34R, approximately $512-475 \mathrm{mbsf}$ ) is characterized by the abundance acme of Xenikoon australis. In addition, Elytrocysta druggii is common to abundant, and Palaeohystrichophora infusorioides has its LO within the subzone.

Subzone C-2 (Cores 120-748C-33R through 120-748C-28R, approximately $475-418 \mathrm{mbsf}$ ) is characterized by the abundance acme of Satyrodinium haumuriense and the presence of Isabelidinium pellucidum. Species diversity in Subzone C-2 is lower than in Subzone C-1.
Satyrodinium haumuriense was described from the Maestrichtian of New Zealand (Wilson, 1984), and S. bengalense was reported from the Campanian at Deep Sea Drilling Project (DSDP) Site 217 in the Indian Ocean (Lentin and Manum, 1986). Elytrocysta druggii has a range of Campanian to Danian (Drugg, 1967; McIntyre, 1975; Ioannides, 1986). Isabelidinium pellucidum has a previously recorded range from Campanian to Maestrichtian (see Appendix B), Cerodinium diebelii ranges from Coniacian to Maestrichtian (Appendix B), and Fromea chytra was described from the Santonin to basal Danian (Drugg, 1967). Xenikoon australis was reported only from the lower Campanian in Australia (Helby et al., 1987), whereas in North America it has 
Table 1 (continued).

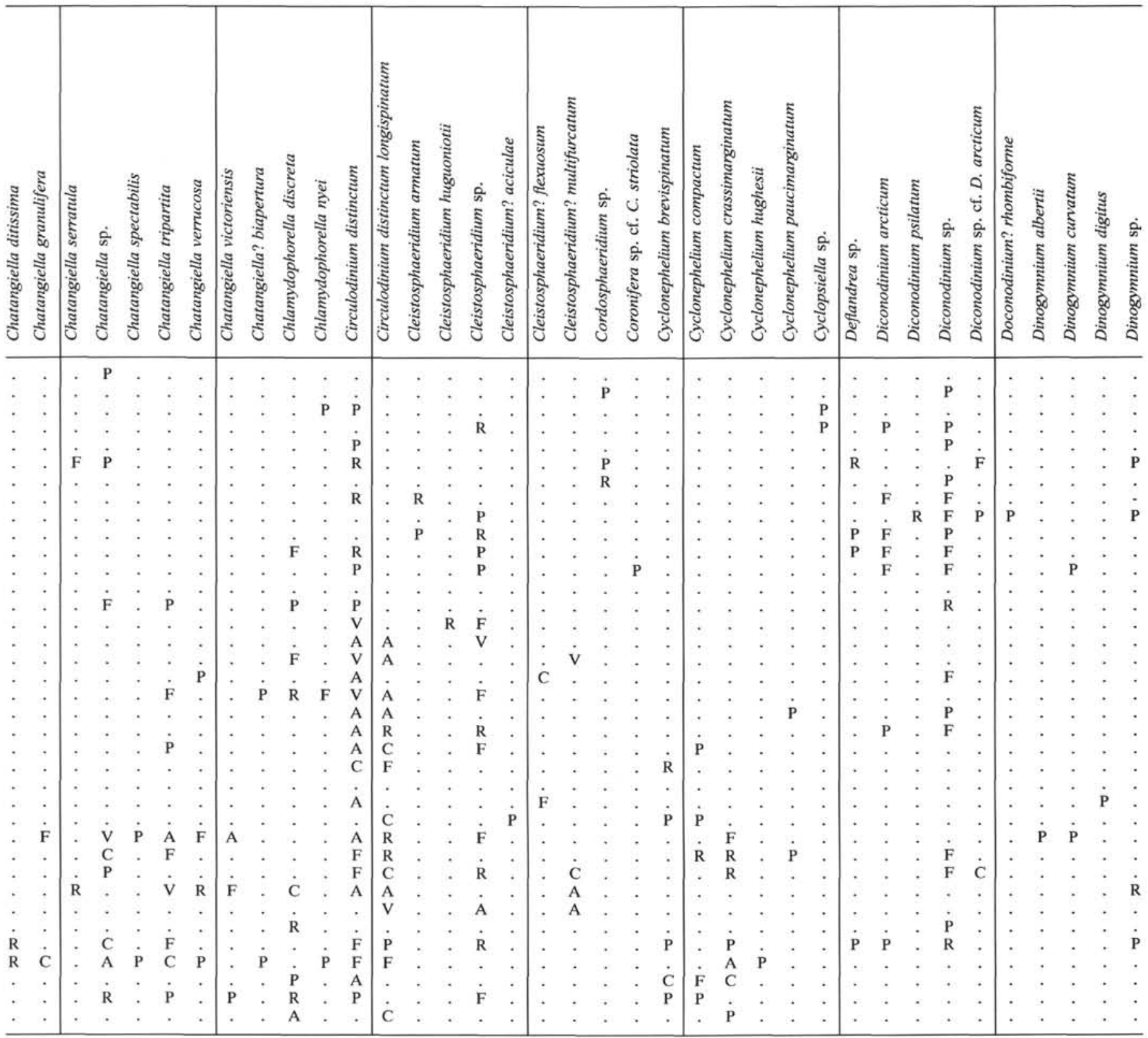

been found from the lower to upper Maestrichtian (Benson, 1976; Firth, 1987). Because Zone B is late Campanian, it is suggested that Zone $C$ is early Maestrichtian, which would agree with the nannofossil data (Watkins, this volume; Fig. 5).

Dinocyst Zone D (recognized only in Sample 120-748C-27R-2, 11-14 cm, approximately 418-407 mbsf)

Zone $\mathrm{D}$ is distinguished from the underlying three zones by its low species diversity and poor preservation. The zone contains only 12 taxa, dominated by Eurydinium ellipticum n. sp. and Isabelidinium cretaceum gravidum $\mathrm{n}$. subsp. The latter subspecies is similar to Isabelidinium cretaceum from the Maestrichtian of arctic Canada (Ioannides, 1986, pl. 15, figs. 5-7) and to Isabelidinium greenense from the Campanian of southeastern Australia (Marshall, 1990, fig. 21, D and E only). Odontochitina spinosa was described from the Maestrichtian of New Zealand (Wilson, 1984). It is reasonable to date Zone D as Maestrichtian in age, and a late Maestrichtian age for Zone D is in agreement with the nannofossil stratigraphy (Watkins, this volume). The absence of the late Maestrichtian-basal Danian Manumiella druggii Zone of Helby et al. may suggest that Zone D probably represents the early late Maestrichtian, and the uppermost Maestrichtian may be missing.

Although Campanian to Maestrichtian dinocyst assemblages have been widely studied in the Arctic, Europe, North America, Australia, and New Zealand, precise correlation of the present zones with other proposed zonations remains difficult. The Australian zonation given by Helby et al. (1987) provides the best correlation (Fig. 7). The five zones of their Isabelidinium Superzone, which in ascending order are the Odontochitina porifera Zone, Isabelidinium cretaceum Zone, Nelsoniella aceras Zone, Xenikoon australis Zone, and Isabelidinium korojonense Zone, were dated as early Santonian to early Maestrichtian. In this paper, the Subzones B-1, B-2, 
Table 1 (continued).

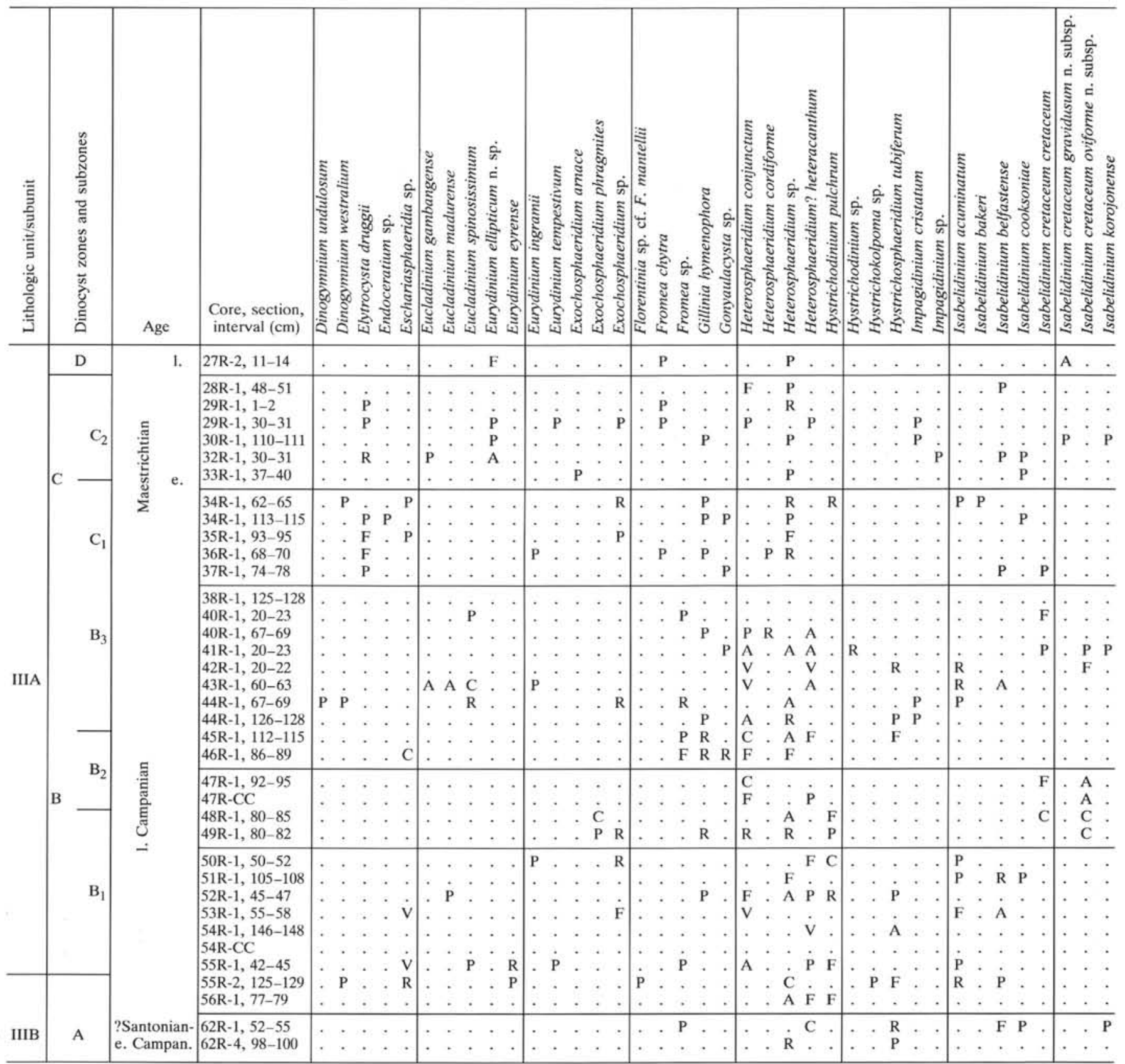

B-3, C-1, and C-2 correlate approximately to their five zones, respectively, but the ranges of some important species in the subzones of this paper are different from those in the zones of Helby et al. (Fig. 7). The age assignment for our five subzones, therefore, is from late Campanian to early Maestrichtian based on the worldwide known ranges of those species. This assignment is in better agreement with the dates from nannofossils as well (Watkins, this volume). The reasons that result in such discrepancy as one stage in age between the two zonation schemes are unknown now. Further studies in this region may find the correct answer. Anyway, a multidisciplinary approach should be to date sediments in areas under new investigation if possible.

\section{PALEOENVIRONMENTAL INTERPRETATION AND DINOFLAGELLATE PROVINCIALISM}

Wall et al. (1977) studied dinocyst distributions in modern marine sediments and considered that these clearly showed both latitudinal-climatic and onshore-offshore trends, as evidenced by the data from four marine environments. These environments are estuarine, neritic, transitional neritic-ocean, and oceanic (pelagic), which correspond to the following four physiographic units: estuaries, continental shelves, continental slope-rise, and abyssal zones, respectively. Dinocyst assemblages from the different environments show distinct changes in three aspects: assemblage composition, species 
Table 1 (continued).

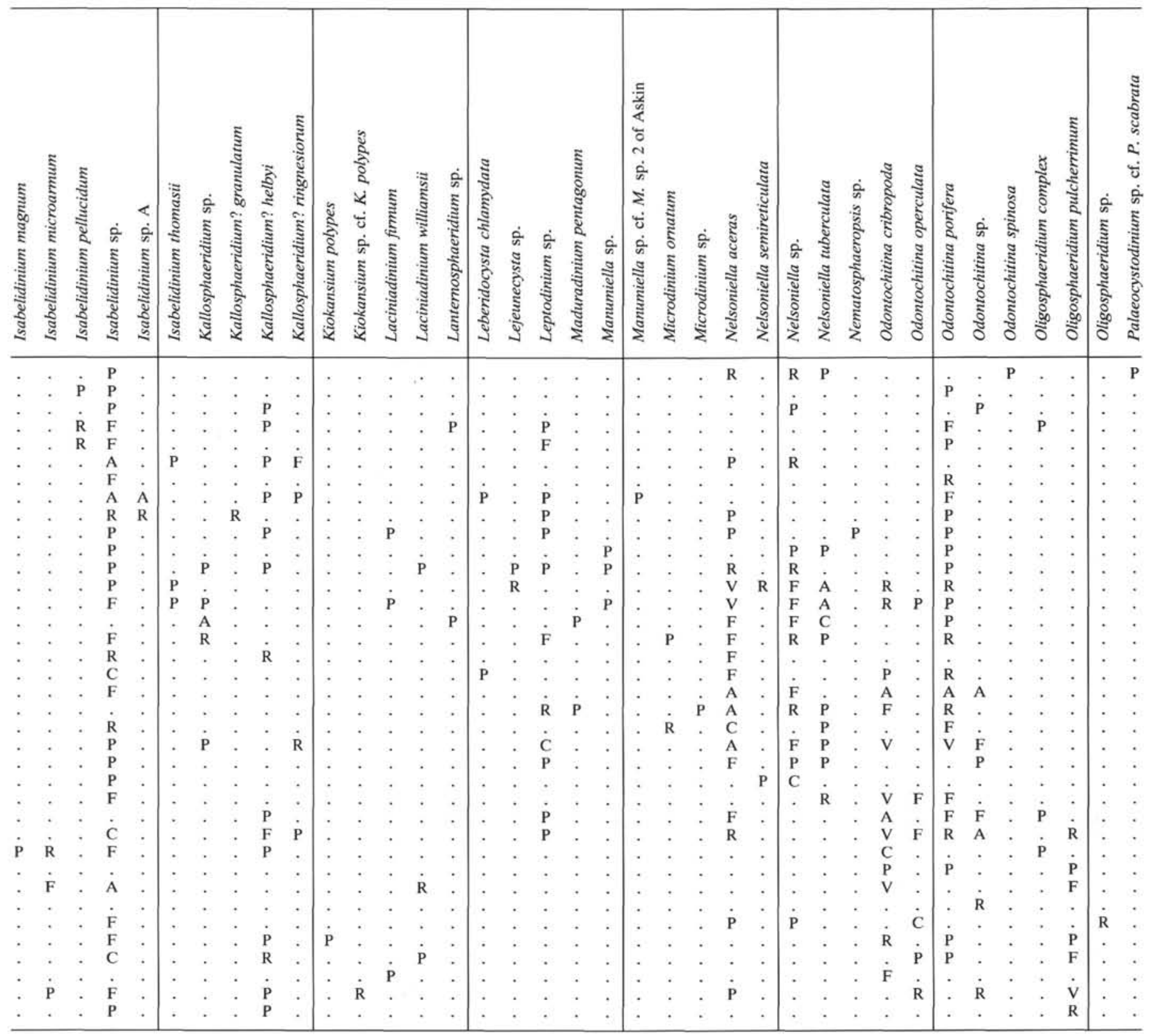

diversity, and specimen abundance. For example, assemblages from cool temperate, brackish stratified estuary environments are dominated by Operculodinium centrocarpum with a smaller proportion of Spiniferites bulloides, Peridinium (now Protoperidinium) (including grouped Peridinium species), $P$. conicum, and $P$. pentagonum and minor numbers of Nematosphaeropsis balcombiana and Tectatodinium pellitum. Assemblages dominated by either Operculodinium centrocarpum or by grouped Peridinium (now Protoperidinium) species and with $P$. conicum with minor numbers of Spiniferites bulloides and $S$. mirabilis indicate a temperate, low to medium salinity, seasonally stratified neritic environment, whereas assemblages from the tropical-subtropical open-sea environment are characterized by the dominance of Leptodinium (now Impagidinium: I. aculeatum, I. strialatum, I. paradoxum, I. sphaericum, and I. patulum) with Operculodinium centrocarpum and Spiniferites ramosus common in samples. Species diversity in different environments as indi- cated by the Hurlbert Index value varies from 1.4-10.5 (estuarine), to 3.6-8.0 (continental shelf), to 3.7-9.2 (continental slope-rise), and to 7.7-12.1 (intercontinental sea). The highest values for the index were generally encountered in warm-water environments. The specimen abundance (or specimen density) measured as the number of cysts per gram of sediment was clearly higher in sediments of the slope-rise zone than in all others. Harland (1983) illustrated some of Wall et al.'s conclusions with his distribution maps of several common species. A number of other studies of dinocysts from both modern and Quaternary sediments indicated that climate variations, water salinity, and ocean currents cause fluctuations in the dinocyst assemblages or communities (Rossignol, 1961, 1962; Wall, 1967; Wall and Dale, 1968; Harland, 1983).

It is difficult to interpret paleoenvironments for the preQuaternary as precisely as for the modern and Quaternary based on dinocysts alone. However, studies based on modern and Quaternary dinocysts can give important clues to pre- 
Table 1 (continued).

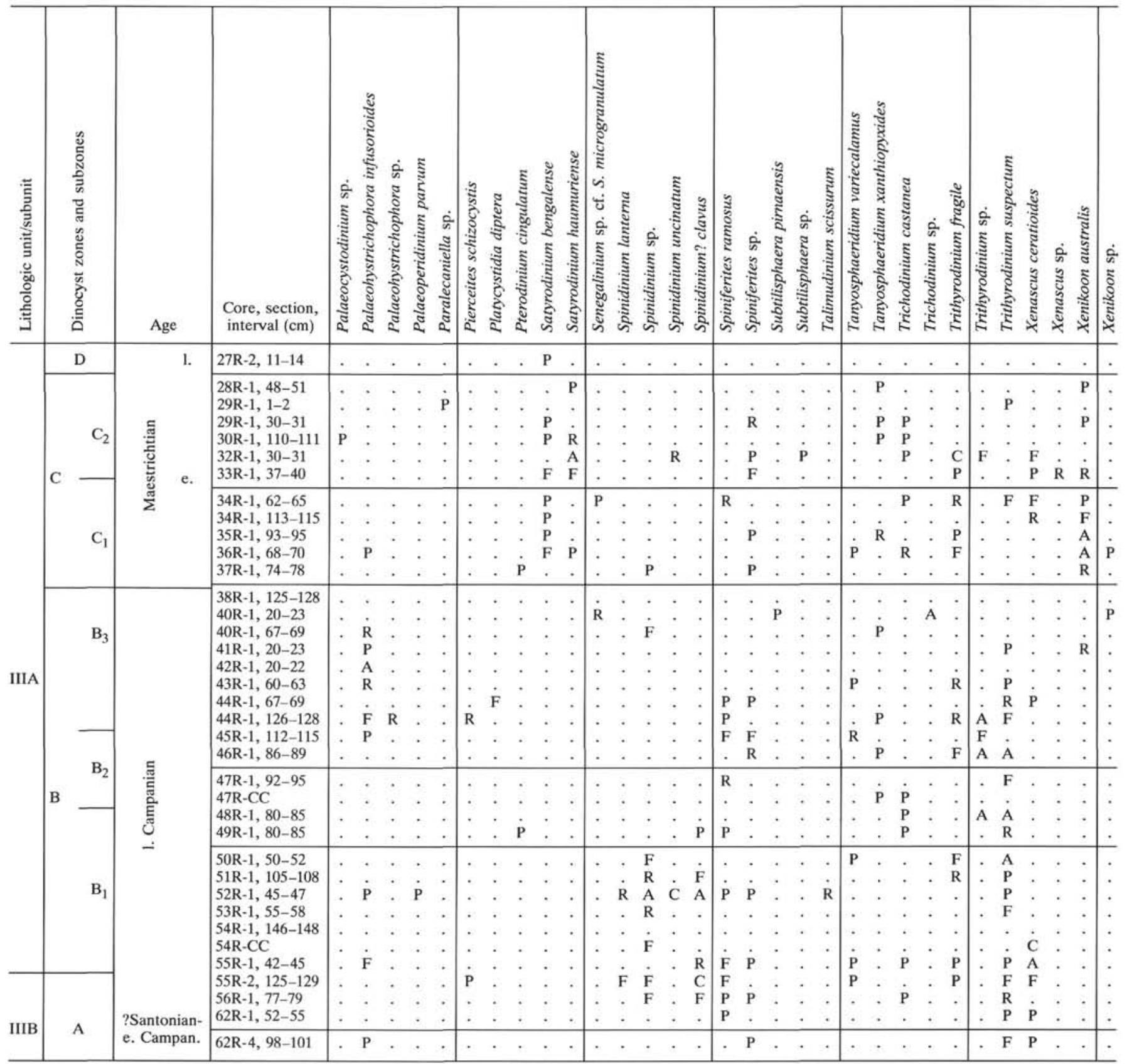

Pleistocene environmental interpretations. Many attempts have been made since the 1960 s to provide paleoenvironmental interpretation on the basis of dinocyst assemblages or communities (Vozzhennikova, 1965, 1967, 1979; Scull et al., 1966; Gruas-Cavagnetto, 1967, 1968; Davey, 1970, 1971; Downie et al., 1971; Harland, 1973; Goodman, 1979; Chateauneuf, 1980; May, 1980; Mao and Norris, 1988; Williams and Bujak, 1977). In these previous studies, the following factors have been used to interpret the paleoenvironment: (1) specimen abundance, (2) cyst types and their relative abundances, (3) content of reworked cysts, and (4) state of preservation. In addition, the occurrences and abundances of other palynomorphs, microfossils, and nannofossils as well as lithologic characters should be considered, and provincial control may be seen in some areas. The present study is based mainly on information from dinoflagellates, but has been integrated with data from other fossils and petrologic analyses.

Planktonic foraminifers were found only in Sample 120. $748 \mathrm{C}-27 \mathrm{R}-1,90-92 \mathrm{~cm}$. Below this sample the fauna is dominated by bryozoans and echinoid and crinoid debris, with benthic foraminifers of small size constituting only a minor part. Calcareous nannofossils occur from Cores $120-748 \mathrm{C}-27 \mathrm{R}$ through $120-748 \mathrm{C}-56 \mathrm{R}$ (407-711 mbsf) and make up only a small proportion of the sediments. The sequence from Core $120-748 \mathrm{C}-62 \mathrm{R}$, where dinocysts were recovered, is barren of calcareous nannofossils. Diatoms and radiolarians were found in Cores 120-748C-46R through 120-748C-48R, and in Sections $120-748 \mathrm{C}-45 \mathrm{R}-\mathrm{CC}$ through $120-748 \mathrm{C}-53 \mathrm{R}-\mathrm{CC}$, respectively. In addition, Sample 120-748C-27R-1, 89-91 cm, contains radiolarians (Schlich, Wise, et al., 1989; Fig. 8). 


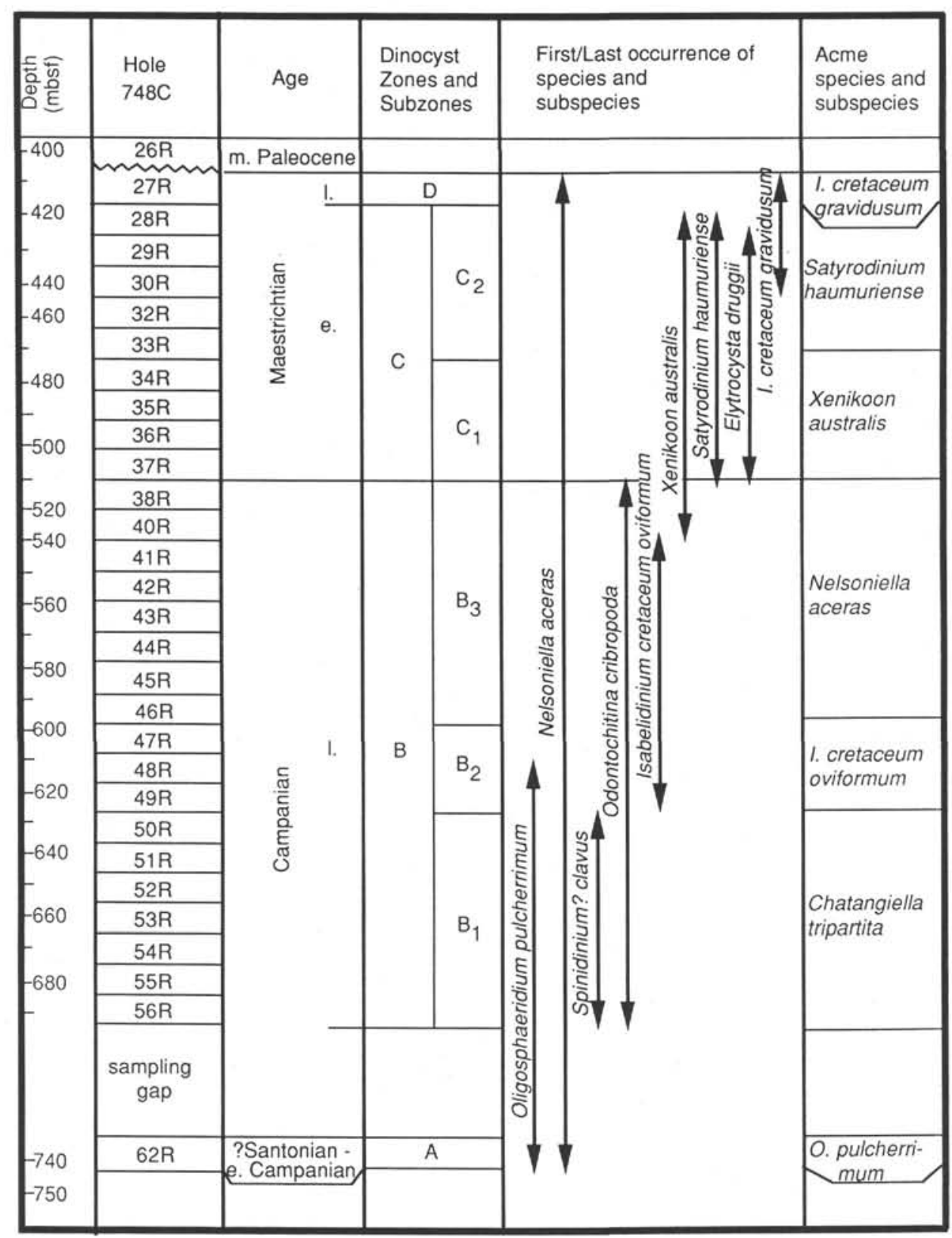

Figure 3. Dinoflagellate assemblage zones and subzones defined by the first and/or last occurrence and abundance acme of species, Hole $748 \mathrm{C}$.

The lithology of Subunit IIIA (dinocyst Zones B-D) is composed of intermittently silica-cemented glauconitic rudstones, grainstones, and packstones, which contain 5\%-65\% glauconite grains and have bioclasts of bryozoans and inoceramids as the dominant components. The upper part of Subunit IIIB (dinocyst Zone A included) consists of glauconitic sandstones, and clayey sandstones (Schlich, Wise, et al., 1989).

All samples studied for this paper from Site 748 contain dinocysts, but are variable in specimen abundance throughout (Table 2 and Fig. 9). For example, dinocyst assemblages in Zone B contain the most abundant specimens, with an average count of about 287 specimens per slide, whereas above Core $120-748 \mathrm{C}-38 \mathrm{R}$ this figure decreases dramatically to about 55 specimens per slide. Although the counts are not absolute counts per gram of sample, they can be used as guides to indicate grossly the dinocyst productivity and applied for a rough paleoenvironmental interpretation. It is likely that the counts represent diminished absolute counts, if all of the slides were of a uniform density, because of the general tendency that the greater the volume of sample residue produced, the greater abundance of dinocyst specimens that residue will contain. Exceptions to this are rare. Reworked Early Cretaceous dinocysts are insignificant, and spores and pollen are very rare and occur only sporadically in the upper part of the interval studied (Maestrichtian).

The general aspects of dinocyst assemblages indicate that this portion of the Kerguelen Plateau was under shallowwater conditions similar to environments from the continental shelf to upper slope, with a water depth of tens to hundreds of meters, during ?Santonian-Campanian to Maestrichtian time, in comparison to the distribution patterns of 


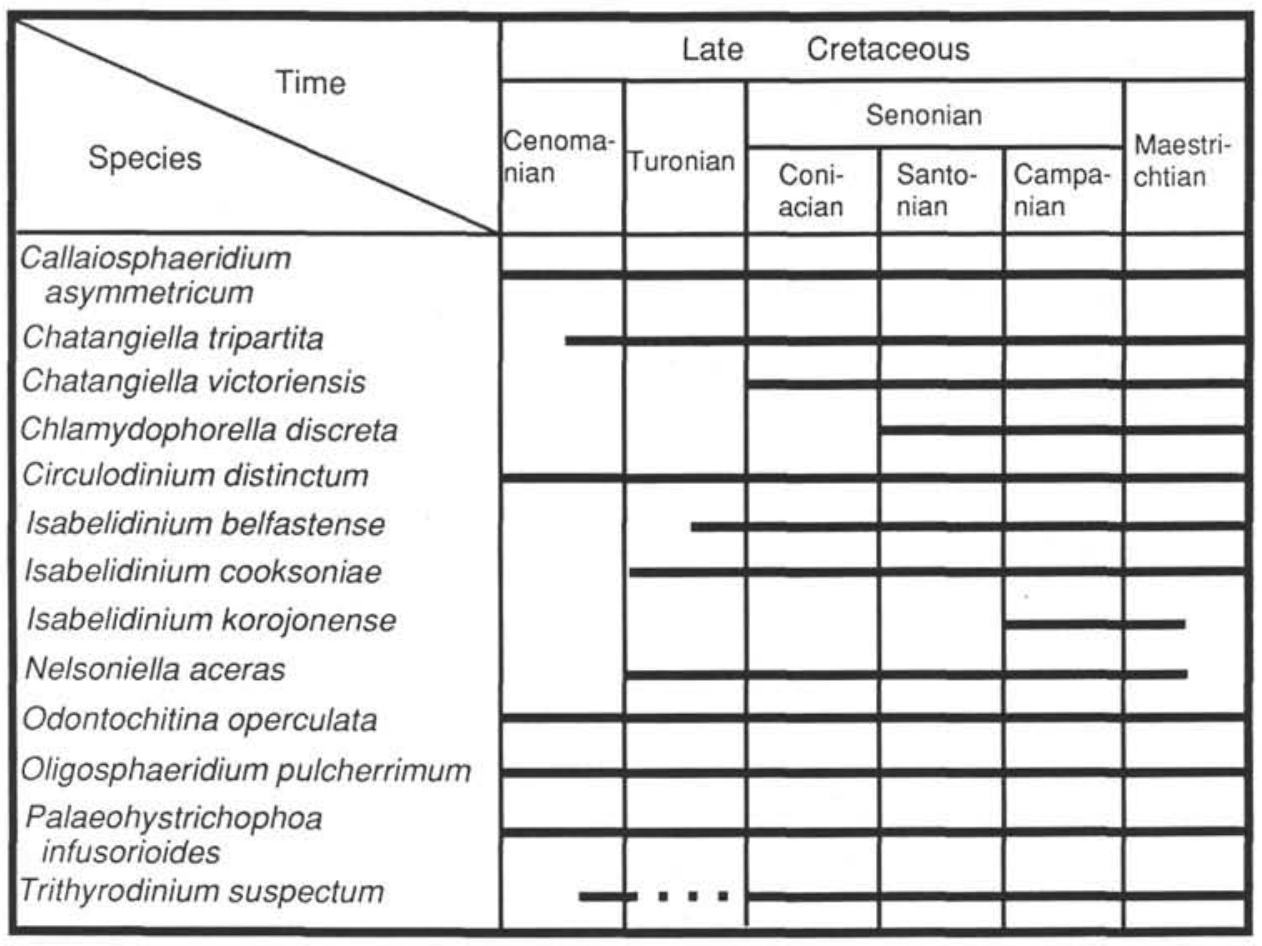

Figure 4. Range of selected species from Zone A.

palynomorphs, nannofossils, and foraminifers summarized by Stover and Williams (1982; Fig. 10). During the ?Santonian-early Campanian, the study area was as shallow as the nearshore (inner part of continental shelf) environment, but isolated from the main continents of the Southern Hemisphere, judging from the less abundant dinocyst specimens and lower species diversity and the very rare occurrence of spores in dinocyst Zone A. The lack of nannofossils, planktonic foraminifers, and siliceous microfossils as well as the coarser sandy sediments in the same interval also supports this conclusion. During the late Campanian the area deepened and was similar to the outer part of a continental shelf and the inner part of a continental slope environment, as evidenced by the abundant dinocyst specimens, the high species diversity, and higher percentage of gonyaulacoid, chorate cysts in Zone B and the occurrences of nannofossils, foraminifers, radiolarians, and diatoms. The Late Cretaceous regression from the plateau may have started in the early Maestrichtian, and small islands may have existed not far from the study area, as suggested by the decrease in dinocyst specimen abundance and species diversity, as well as by the higher percentage of peridinioid and cavate + proximate cysts in Zone C (Figs. 8-10). The increase in oxidized, poorly preserved dinocysts and the increase in pollen and spores toward the upper part of the section (dinocyst Zones C and D) also support this interpretation. During the course of the Late Cretaceous regression the possible occurrence of a short period of transgression is based on the presence of calcareous nannofossils, planktonic foraminifers, and radiolarians in samples from Core $120-748 \mathrm{C}-27 \mathrm{R}$, but during most of the late Maestrichtian, the study area might have been above sea level and experienced weathering and erosion, as marked by a discontinuity above the top of Core 120-748C-27R (Schlich, Wise, et al., 1989).

Fossil dinoflagellate provincialism has not yet been well studied, and only one paper dealing with Late Cretaceous peridiniacean dinoflagellate provincialism is available (Lentin and Williams, 1980). In that monograph the authors presented a Late Cretaceous paleobiogeographic map integrated with both information on the Campanian dinocyst assemblages from all over the world and data from other sources. Three realms were delineated and three peridiniacean dinoflagellate suites (provinces) were proposed by Lentin and Williams (1980). Data from the Southern Hemisphere, particularly from the Indian Ocean, however, are scare. The present work will add information from the study area and will complement the Late Cretaceous dinoflagellate provincialism of Lentin and Williams's scheme.

The Campanian-Maestrichtian dinoflagellate assemblage from the study area bears a strong affinity to Australian assemblages (Table 3), which are characterized by having more peridinioid and cavate cysts than gonyaulacoid and chorate cysts (Fig. 9). Isabelidinium, Chatangiella, and Nelsoniella are abundant and occur continuously in the assemblage. Chatangiella illustrates a high species diversity and is large in size. Spiniferites is never abundant and is also low in species diversity in the assemblage. Andalusiella and Senegalinium are almost absent from the assemblage. Amphidiadema, Nelsoniella, Satyrodinium, and Xenikoon are probably endemic genera for this area. Taking this evidence into account, a different province from those of the North Pacific, North Atlantic, and Caribbean might have existed in the Southern Hemisphere during the Campanian to Maestrichtian. We tentatively name it the South Indian province (Helby suite), indicating a cool temperate climate in the Southern Hemisphere (Fig. 11).

\section{CONCLUSIONS}

Dinoflagellates have proven to be useful for stratigraphic investigations and paleoenvironmental reconstructions of upper Mesozoic strata drilled during Leg 120 on the Southern Kerguelen Plateau. The age of the interval from Core 120748C-27R through Section 120-748C-62R-4 is ?Santonianearly Campanian to late Maestrichtian based primarily on 


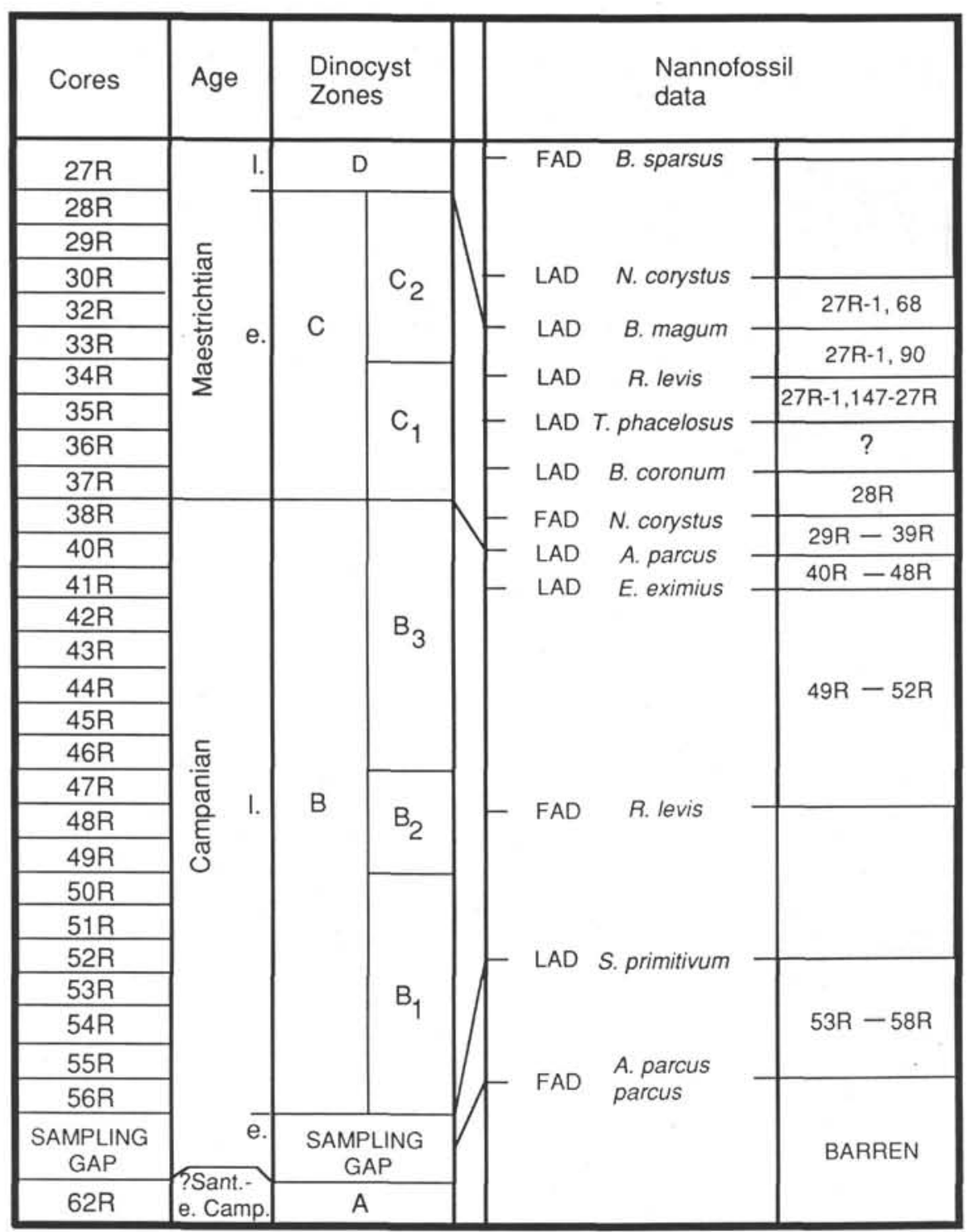

Figure 5. Correlation of dinocyst zonation and nannofossil data, Hole 748C.

dinoflagellate assemblages, which is in good agreement with the nannofossil data. As interpreted from dinoflagellates and integrated with information from other disciplines, Site 748 was located on a shallow submerged plateau, isolated from the main continents of the Southern Hemisphere during that time. The Late Cretaceous transgressions and regressions over the plateau during this period were also traced by means of dinoflagellates and other fossils. A South Indian cool temperate dinoflagellate province (tentatively named the Helby suite) is proposed based on brief comparisons of the Campanian to Maestrichtian dinoflagellate assemblages at Site 748 with those from other parts of the world.

\section{SYSTEMATIC DESCRIPTIONS}

A specimen designation such as 1-12.5/98.5 indicates the slide number of the sample (1) with coordinates (12.5/98.5) valid for Zeiss Photomicroscope III no. 0378 in the Nannofossil Laboratory of the Department of Geology, Florida State University.
Division PYRHOPHYTA Pascher, 1914

Class DINOPHYCEAE Fritsch, 1927

Order PERIDINIALES Haeckel, 1894

Suborder PERIDINIINEAE Fott, 1959, emend. Bujak and Davies, 1983

Family DEFLANDREACEAE Eisenack, 1954, emend. Bujak and Davies, 1983

Subfamily DEFLANDREOIDEAE Bujak and Davies, 1983

Genus ABRATOPDINIUM n. gen.

Derivation of name. From the Greek $a b r$, meaning graceful, exquisite, and atop, meaning bizarre, in reference to the general appearance of the cyst, that is, its thin, transparent wall and shape.

Type species. Abratopdinium kerguelense n. gen., n. sp., upper Campanian to lower Maestrichtian of Hole 748C.

Description. Circumcavate cysts, ambital outline circular, subcircular, to heartlike. Both periphragm and endophragm thin and hyaline; periphragm smooth or with features of low relief; endophragm smooth. Paracingulum generally indicated by ridges only seen marginally, seldom by sparse verrucae seen on the surface. Parasulcus, where present, limited to the hypocyst. Archeopyle intercalary [2a], 
Table 2. Count of encountered dinocyst specimens per slide and percentage of cysts in each sample.

\begin{tabular}{|c|c|c|c|c|c|}
\hline \multirow{2}{*}{ 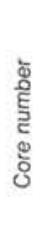 } & \multirow{2}{*}{ 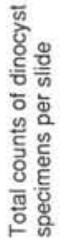 } & \multicolumn{4}{|c|}{ Relative abundance (\%) } \\
\hline & & $\begin{array}{l}\text { Proximate } \\
\text { and cavate } \\
\text { cysts }\end{array}$ & Chorate cyst & $\begin{array}{l}\text { Peridinioid } \\
\text { cysts }\end{array}$ & $\begin{array}{l}\text { Gonyaulacoid } \\
\text { cysts }\end{array}$ \\
\hline $27 R$ & 38 & 100 & 0 & 94.5 & 5.5 \\
\hline $28 \mathrm{R}$ & 9 & 65 & 35 & 38 & 62 \\
\hline $29 \mathrm{~A}$ & 21 & 75 & 25 & 32 & 68 \\
\hline $30 R$ & 22 & 82.5 & 17.5 & 59 & 41 \\
\hline $32 R$ & 170 & 99 & 1 & 87.5 & 12.5 \\
\hline $33 R$ & 30 & 78 & 22 & 54.5 & 46 \\
\hline $34 \mathrm{R}$ & 69 & 88 & 12 & 64 & 36 \\
\hline $35 R$ & 76 & 85 & 15 & 62.5 & 37.5 \\
\hline $36 \mathrm{R}$ & 79 & 92.5 & 7.5 & 76 & 24 \\
\hline $37 R$ & 31 & 86.5 & 13.5 & 61 & 39 \\
\hline $38 \mathrm{R}$ & 168 & 100 & 0 & 96 & 4 \\
\hline $40 R$ & 228 & 70 & 30 & 57.5 & 42.5 \\
\hline $41 R$ & 319 & 33 & 67 & 9 & 91 \\
\hline $42 R$ & 424 & 33 & 67 & 7 & 93 \\
\hline 43R & 321 & 56 & 44 & 31 & 69 \\
\hline $44 \mathrm{R}$ & 188 & 73 & 27 & 61 & 39 \\
\hline $45 \mathrm{R}$ & 233 & 51 & 49 & 17 & 83 \\
\hline $46 \mathrm{~A}$ & 351 & 92 & 8 & 24 & 76 \\
\hline $47 \pi$ & 66 & 71 & 29 & 62.5 & 37.5 \\
\hline $48 R$ & 468 & 58 & 42 & 20 & 80 \\
\hline 49R & 95 & 67 & 33 & 26 & 74 \\
\hline $50 R$ & 435 & 94 & 6 & 66.5 & 33.5 \\
\hline $51 R$ & 67 & 87.5 & 12.5 & 55.5 & 44.5 \\
\hline $52 R$ & 191 & 63 & 37 & 55 & 45 \\
\hline $53 R$ & 950 & 75 & 25 & 36 & 64 \\
\hline $54 \mathrm{R}$ & 276 & 14 & 86 & 14 & 86 \\
\hline 55R & 186 & 81.5 & 18.5 & 42 & 58 \\
\hline $56 \mathrm{R}$ & 127 & 49 & 51 & 7.5 & 92.5 \\
\hline $62 \mathrm{~A}$ & 114 & 42 & 57 & 12.5 & 87.5 \\
\hline
\end{tabular}

standard hexastyle, iso-thetaform or rounded at each corner, $\mathrm{AI}=$ 0.53-0.63; operculum free.

Remarks. Abratopdinium differs from any published genus in its thin and hyaline wall, small to medium size, archeopyle type, and rounded shape with no distinct horns. Nelsoniella, which may have a similar outline, has a thicker wall and is epicavate only.

\section{Abratopdinium cardioforme $\mathrm{n}$. sp.}

(Plate 1, Figs. 3-4)

Derivation of name. From the Greek cardi, meaning heart, with reference to the shape of cyst.

Description. Cyst circumcavate, ambital outline heartlike, rounded rhombic to rounded pentagonal. Epicyst is rounded triangular; hypocyst is rounded or slightly concave at antapex, but without any indications of horns or projections. Wall two layered; both periphragm and endophragm are thin. The periphragm is smooth or with scattered apiculae of about $1 \times 1 \mu \mathrm{m}$; the endophragm is smooth and hyaline, as a result, the endocyst is faintly visible. Paracingulum usually present, slightly levorotatory, 4-7 $\mu \mathrm{m}$ wide, indicated by low ridges, clearly seen along the cyst margin. Parasulcus, where present, is limited to the hypocyst. Archeopyle intercalary [2a], standard hexastyle, iso-thetaform; operculum usually free.

Comparison. Abratopdinium cardioforme differs from A. kerguelense in its heartlike shape and delicately apiculate periphragm.

Occurrence. Rare to common in Zones B to C of the upper Campanian to lower Maestrichtian.

Size. Length of cysts, $34.5-49$ (holotype 45.8$) \mu \mathrm{m}$; width of cysts, 33-53.2 (holotype 53.1) $\mu \mathrm{m} ; 20$ specimens measured.

Holotype. USNM No. 453932 (Plate 1, Fig. 4; 1-128/4.5) $\mathrm{cm}$

Type locality. South Indian Ocean, Sample 120-748C-40R-1, 20-23
Abratopdinium kerguelense $\mathrm{n}$. sp.

(Plate 1, Figs. 1-2 and 6)

Derivation of name. From the name Kerguelen, with reference to the Kerguelen Plateau, the operational area for Leg 120.

Description. Cyst circumcavate, spherical to subspherical. Both apex and antapex rounded without any horns or projections. Wall two layered; both periphragm and endophragm are thin and hyaline. Periphragm smooth, some with folds usually parallel to the outline or ornamented with verrucae $1.5-2.5 \mu \mathrm{m}$ across and 2-3.5 $\mu \mathrm{m}$ apart. The verrucae, where present, delineate the paracingulum. The width of lateral pericoel varies, depending on the relative size of the endocyst, usually about one-third to one-tenth of the total width of the cyst. Endocyst spherical to subspherical. Paracingulum usually present, 5-7 $\mu \mathrm{m}$ wide, slightly lavorotatory, indicated by two rows of low ridges, some of which are visible only around the cyst margins or rarely indicated by the aligned verrucae. Parasulcus, where present, is limited to the hypocyst, and widened toward the posterior. Archeopyle intercalary [2a], standard hexastyle, iso-thetaform, or rounded at each corner; operculum usually free.

Size. Length of cysts, $36.5-51$ (holotype 47.6$) \mu \mathrm{m}$; width of cysts, 39.5-53 (holotype 44) $\mu \mathrm{m} ; 20$ specimens measured.

Occurrence. Few to abundant in Zones B to C of the upper Campanian to lower Maestrichtian.

Holotype. USNM no. 453931 (Plate 1, Fig. 1; 4-126/6.5).

Type locality. South Indian Ocean, Sample 120-748C-36R-1, 68-70 $\mathrm{cm}$.

\section{Genus EURYDINIUM Stover and Evitt, 1978}

Eurydinium ellipticum $\mathrm{n}$. sp.

(Plate 2, Figs. 1-2 and 8-9; Plate 10, Fig. 1)

Derivation of name. From the Latin ellipticus, elliptical, with reference to the general shape of the cyst.

Description. Cyst circumcavate. Apex rounded, truncate, or slightly concave in the middle anterior without any horns or projections; antapex almost rounded or slightly asymmetrical with one corner less rounded than the other. Endocyst subcircular to elliptical in outline. Wall two layered; both periphragm and endophragm are thin and smooth. Ambital pericoel, where developed, is as narrow as less than one-tenth of the total width of the cyst. Archeopyle intercalary [2a], standard hexastyle, iso-thetaform, some rounded at each corner; $\mathrm{AI}=0.48-0.61$; operculum usually free. No indications of paracingulum or parasulcus are present.

Discussion. This species is distinguished by its elliptical shape with no apical or antapical horns, for which reason it is better allocated to genus Eurydinium than to Isabelidinium or Manumiella (Stover and Evitt, 1978; Stover and Williams, 1987). The large size and the elliptical shape of the species distinguish it from any previously described species of Eurydinium.

Occurrence. Few to abundant in Subzone C-2 and Zone D of the Maestrichtian.

Size. Length of cysts, 78.5-100.5 (holotype 100) $\mu \mathrm{m}$; width of cysts, 47.5-86.5 (holotype 71) $\mu \mathrm{m} ; 20$ specimens measured.

Holotype. USNM No. 453933 (Plate 2, Fig. 9; 2-127.5/6).

Type locality. South Indian Ocean, Sample 120-748C-32R-1, 30-31 $\mathrm{cm}$.

Isabelidinium cretaceum (Cookson) Lentin and Williams

Deflandrea cretacea Cookson, 1956, pp. 184-185, pl. 1, figs. 1-4 and

7 , non figs. 5-6.

Isabelia cretacea (Cookson) Lentin and Williams, 1976, p. 57.

Isabelidinium cretaceum (Cookson) Lentin and Williams, 1977, p. 167.

Remarks. Cookson (1956, pp. 184-185) described Deflandrea cretacea from the Upper Cretaceous of Nelson Bore, Victoria, Australia, as a circumcavate-bicavate cyst with a concave, rounded, or broadly tapered antapex. The illustration of the holotype shows a slightly concave posterior with two shallow antapical lobes and very narrow lateral pericoels. Since then the species has been transferred to the genera Isabelia,elidinium, and then questionably Manumiella (Bujak and Davies, 1983). I. cretaceum has been identified by a number of palynologists. We consider that the species should remain in the genus Isabelidinium on the basis that its main features are closer to Isabelidinium than to Manumiella. 


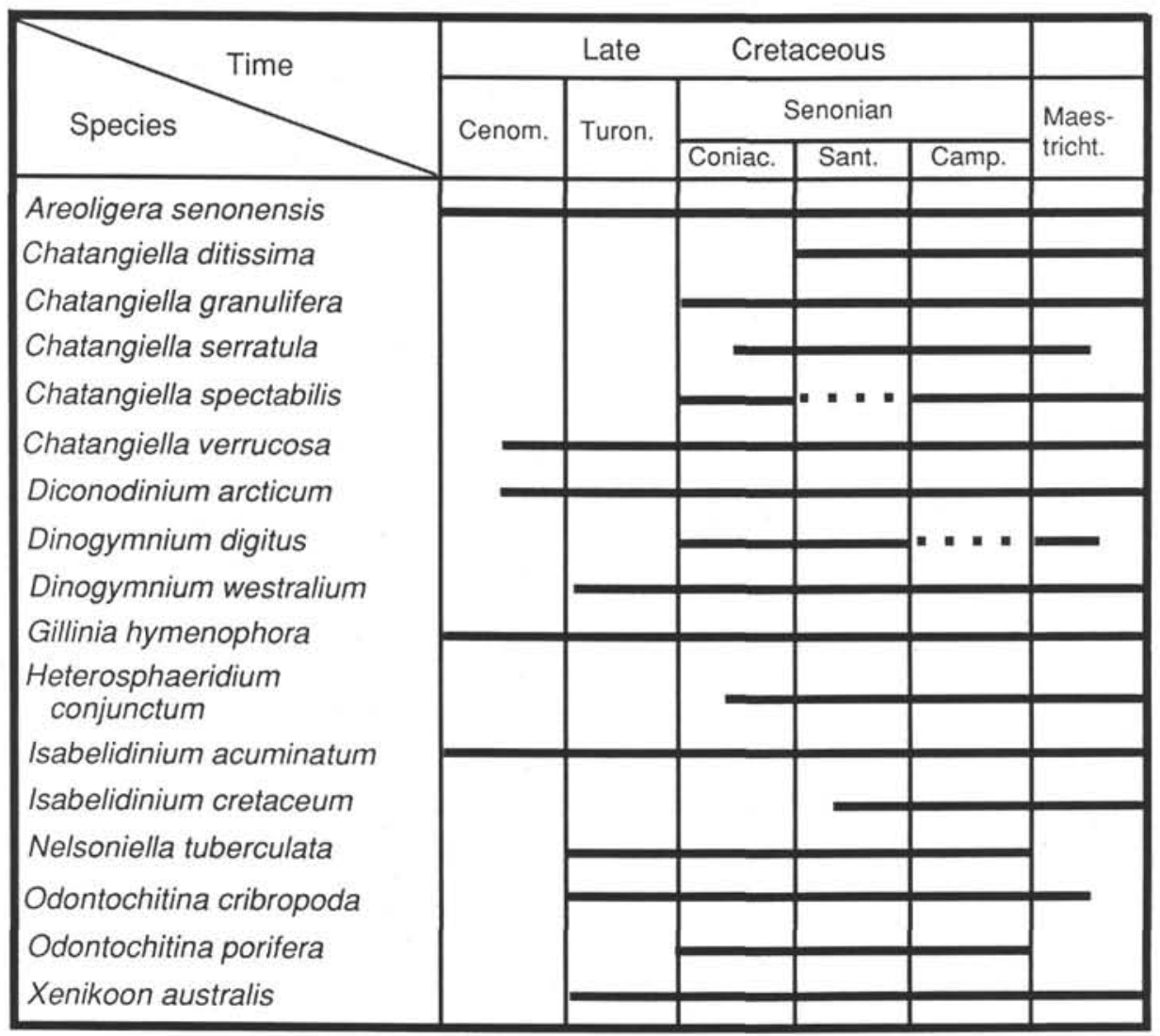

Figure 6. Range of selected species from Zone B.

Isabelidinium cretaceum cretaceum

(Plate 1, Fig. 10; Plate 10, Fig. 3; Plate 11, Fig. 6)

Deflandrea cretacea Cookson, 1956, pp. 184-185, pl. 1, figs. 1-3, non figs. 4-7.

Isabelidinium cretaceum (Cookson) Lentin and Williams, 1977, p. 167.

Remarks. The original description of Deflandrea cretacea (Cookson, 1956, pp. 184-185) included a variety of forms. The diagnosis for the present subspecies is featured as the illustration of the holotype (Cookson, 1956, pl. 1, fig. 1) and is bicavate or circumcavate with a very narrow lateral pericoel and has a concave antapex.

Holotype. Cookson (1956, pl. 1, fig. 1).

Type locality. Nelson Bore, Victoria, at 6233, 6065, and $5304 \mathrm{ft}$.

Isabelidinium cretaceum gravidum $\mathrm{n}$. subsp.

(Plate 1, Figs. 11-12)

Deflandrea cretacea Cookson, 1956, pp. 184-185, pl. 1, fig. 4, but not figs. 1-3, 5-7.

Isabelidinium cretaceum (Cookson) Lentin and Williams, Ioannides, 1986 , pl. 15, figs. 5-7.

Isabelidinium cretaceum (Cookson) Lentin and Williams, Askin, 1988, figs. 8-2 and 8-3.

Isabelidinium greenense Marshall, Marshall, 1990, figs. 21-D and 21-E, but not figs. 21-A-21-C, 21-F-21-R, and 22-A-22-D.

Derivation of name. From the Latin gravidus, meaning plump or pregnant, with reference to the expanded endocyst.

Description. Cyst bicavate. Both apex and antapex rounded without horns. Endocyst spherical to transversely elliptical, forming the widest part and occupying the major portion of the cyst. Cyst asymmetrical to both long and short axes or only to long axis with the apical pericoel larger than the antapical pericoel. Wall thin and two layered; both periphragm and endophragm smooth. Archeopyle intercalary [2a], standard hexastyle, iso-thetaform or rounded at each corner; $\mathrm{AI}=0.52-0.65$; operculum free.
Discussion. The range of Isabelidinium cretaceum has been extended from the Santonian (Helby et al., 1987) to the Maestrichtian (Ioannides, 1986) and to the Maestrichtian-Danian (Drugg, 1967). Comparison of the species identified by different authors, however, makes it necessary to subdivide the species into three subspecies to aid in its stratigraphic usage. The present subspecies is characterized by its bicavate cyst and transversely expanded endocyst. The present new subspecies is similar to some specimens of Isabelidinium greenense Marshall, 1990 (figs. 21-D and 21-E only). According to the description (Marshall, 1990, p. 24), "ventro-dorsal outline of endocyst subcircular to ovoidal and longitudinally elongate." Figures 21-D and 21-E, however, show the endocyst to be transversely elliptical rather than longitudinally elongate in outline, which is similar to the present new subspecies. We, therefore, consider them to be conspecies and consubspecies with the present subspecies. The subspecies differs from $I$. cretaceum cretaceum by having a rounded antapex, whereas the latter subspecies has a concave antapex and includes forms of both bicavate cysts and circumcavate cysts with very narrow lateral pericoel.

Occurrence. Few to abundant in Subzone C-2 and Zone D of the lower to upper Maestrichtian.

Size. Length of cysts, $73.5-99.5$ (holotype 90$) \mu \mathrm{m}$; width of cysts, $58.5-80.5$ (holotype 80$) \mu \mathrm{m}$; length of cysts/width of cysts $=1.1-1.6$; 20 specimens measured.

Holotype. USNM No. 453934 (Plate 1, Fig. 11; 6-129/2.5). $\mathrm{cm}$.

Type locality. South Indian Ocean, Sample 120-748C-27R-2, 11-14

Isabelidinium cretaceum oviforme $\mathrm{n}$. subsp.

(Plate 1, Figs. 7 and 9; Plate 10, Fig. 2; Plate 11, Fig. 5)

Deflandrea cretacea (Cookson, 1956), pp. 184-185, pl. 1, fig. 7, but not figs. 1-6.

Deflandrea cretacea (Cookson), Cookson and Eisenack, 1961, p. 7, pl. XI, figs. 1 and 2 . 


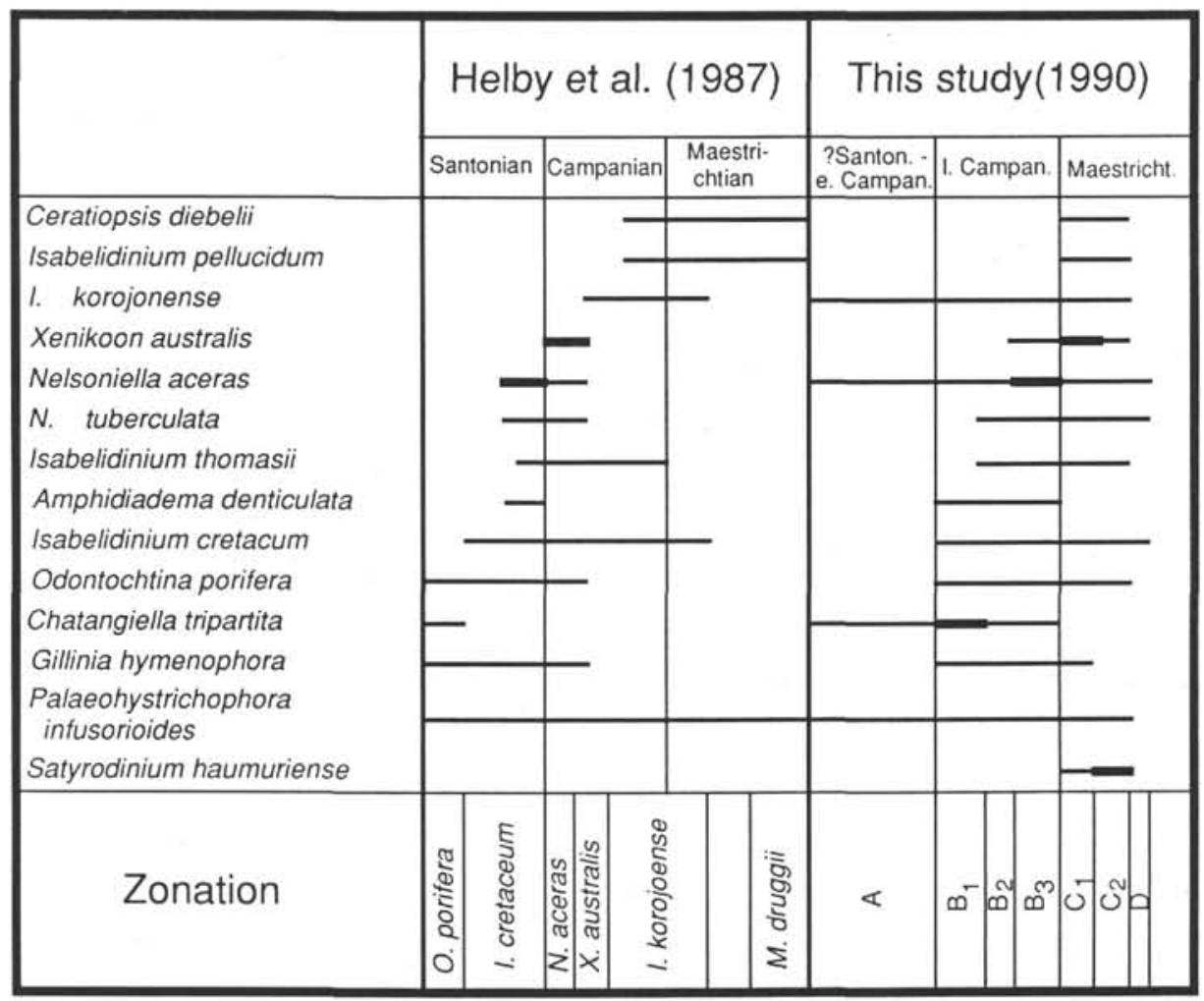

Figure 7. Comparison of dinocyst zones proposed by Helby et al. (1987) and those defined by this study.

Derivation of name. From the Latin oviformis, ovoidal, with reference to the shape of the cyst.

Description. Cyst circumcavate, ovoid. Apex rounded or slightly projecting; antapex broadly tapered, some slightly concave. The apex is always wider and more round than the antapex. Endocyst subspherical, dorsal side more convex than ventral side. The width of the lateral pericoel is commonly narrower than one-tenth of the total width of the cyst. Wall two layered; periphragm smooth or with verrucae on both apical and antapical areas, and endophragm smooth. Parasulcus, where present, is limited to the hypocyst. Archeopyle intercalary, standard hexastyle, iso-deltaform or rounded at each corner; operculum usually free, rarely attached.

Discussion. The subspecies differs from $I$. cretaceum gravidum because it has a circumcavate cyst and ovoid shape with the apex always wider and more rounded than the antapex. 1 . cretaceum cretaceum, according to the holotype (Cookson, 1956, pl. 1, fig. 1), is typically bicavate with a slightly concave antapex.

Occurrence. Common to abundant in Subzone B-2 and few in Subzone B-3 of the upper Campanian.

Size. Length of cysts, 90.5 to 112 (holotype 97.2$) \mu \mathrm{m}$; width of cysts, 80 to 100.5 (holotype 80.2 ) $\mu \mathrm{m} ; 20$ specimens measured.

Holotype. USNM No. 453935 (Plate 1, Fig. 7; 1-97.2/4).

Type locality. South Indian Ocean, Sample 120-748C-47R-CC.

\section{Isabelidinium sp. A}

(Plate 4, Figs. 11-12)

Description. Cyst circumcavate and elongate with one apical and two antapical horns. The lateral sides parallel each other around equatorial area in ambital outline. The apical horn is bluntly pointed or truncated, formed by thickened and folded periphragm; two antapical horns are always pointed and unequal in size with the right one shorter and less pointed than the left one. The endocyst is circular to subcircular in dorso-ventral view, its lateral view is asymmetrical with the dorsal side more prominent than the ventral side. The width of the lateral pericoel is as narrow as one-tenth of the total width of the cyst. Archeopyle intercalary [2a], standard hexastyle, iso-deltaform to iso-thetaform, or rounded at each corner; $\mathrm{AI}=0.40-0.46$; operculum usually free. No indication of paracingulum and parasulcus is present.
Occurrence. Common to abundant in Zone $\mathrm{C}$ of the lower Maestrichtian.

Comparison. The illustrated specimens resemble Isabelidinium glabrum, which was recorded from the Albian to the Cenomanian of Australia (Cookson and Eisenack, 1969), but differ from it by having a more elongated shape and two pointed antapical horns.

Size. Length of cysts, 128-155.5 $\mu \mathrm{m}$; width of cysts, 58.5-82.5 $\mu \mathrm{m}$; length of left antapical horns, $29-38 \mu \mathrm{m}$; length of right antapical horns, 7-11 $\mu \mathrm{m}$; width of endocysts, 55-58.5 $\mu \mathrm{m} ; 20$ specimens measured.

\section{ACKNOWLEDGMENTS}

We wish to extend our warmest thanks to S. W. Wise (Florida State University, Tallahassee), who initiated this study, provided samples for the basis of the work, and gave strong encouragement and help during the preparation of the paper. We would like to express our sincere appreciation to G. L. Williams (Atlantic Geoscience Centre, Geological Survey of Canada) and R. Hedlund (Amoco Production Research Center in Tulsa) for reviewing the manuscript and offering constructive criticism. We also wish to thank J. Lentin (L.I.B. Co., Canada) for useful discussions and numerous valuable suggestions for the revision of the final manuscript. Thanks are extended to J. V. Firth for pointing out some unpublished references. Samples were carefully processed by A. Leemann from ETH-Zürich. This study was supported by Swiss National Funds, USSAC funds, and Ocean Drilling Program Grant 8917976 to S. W. Wise, Jr.

\section{REFERENCES}

Alberti, G., 1959. Zur Kenntnis der Gattung Deflandrea Eisenack (Dinoflag.) in der Kreide und im Alttertiär Nord- und Mitteldeutschlands. Mitt. Geol. Staatsinst. Hamburg, 28:93-105.

Askin, R. A., 1988. Campanian to Paleogene palynological succession of Seymour and adjacent islands, northern Antarctic Peninsula. In 
Feldmann, R. M., and Woodburne, M. O. (Eds.), Geology and Paleontology of Seymour Island, Antarctic Peninsula. Mem. Geol. Soc. Am., 169:131-153.

Aurisano, R. W., 1989. Upper Cretaceous dinoflagellate biostratigraphy of the subsurface Atlantic Coastal Plain of New Jersey and Delaware, U.S.A. Palynology, 13:143-179.

Benson, D. G., 1976. Dinoflagellate taxonomy and stratigraphy at the Cretaceous-Tertiary boundary, Round Bay, Maryland. Tulane Stud. Geol. Paleontol., 12:169-233.

Bujak, J. P., and Davies, E. H., 1983. Modern and fossil Peridiniineae. Am. Assoc. Stratigr. Palynol. Contrib. Ser., 13:1-203.

Chateauneuf, J.-J., 1980. Palynostratigraphie et palèoclimatologie de l'Eocène supérieur et de l'Oligocène du Bassin de Paris. Mem. BRGM, 116:1-360.

Cookson, I. C., 1956. Additional microplankton from Australian Late Mesozoic and Tertiary sediments. Aust. J. Mar. Freshwater Res., 7:183-191.

Cookson, I. C., and Eisenack, A., 1958. Microplankton from Australian and New Guinea upper Mesozoic sediments. Proc. R. Soc. Victoria, 70:19-79.

1960a. Microplankton from Australian Cretaceous sediments. Micropaleontology, 6:1-18.

1960b. Upper Mesozoic microplankton from Australia and New Guinea. Palaeontology, 2:243-261.

1961. Upper Cretaceous microplankton from the Balfast No. 4 Bore, south-western Victoria. Proc. R. Soc. Victoria, 74:69-76.

1962. Additional microplankton from Australian Cretaceous sediments. Micropaleontology, 8:485-507.

1969. Some microplankton from two bores at Balcata, West Australia. J. R. Soc. W. Aust., 52:3-8.

1971. Cretaceous microplankton from the Eucla Basin, Western Australia. Proc. R. Soc. Victoria, 83:137-157. 1974. Microplankton aus australischen Mesozoischen und Tertiären Sedimenten. Palaeontographica B, 148:44-93. 1982. Microfossilien aus australischen Mesozoischen und Tertiären Sedimenten. Zweiter Teil. Palaeontographica B, 184:23-63.

Davey, R. J., 1970. Non-calcareous microplankton from the Cenomanian of England, northern France and North America, Part 2. Bull. Br. Mus. Nat. Hist. (Geol.), 18:333-397.

1971. Palynology and palaeo-environmental studies, with special reference to the continental shelf sediments of South Africa. In Farinacci, A. (Ed.), Proc. 2nd Planktonic Conf., Rome 1970. Rome (Edizioni Technoscienza), 1:331-347.

Deflandre, G., and Cookson, I. C., 1955. Fossil microplankton from Australian late Mesozoic and Tertiary sediments. Aust. J. Mar. Freshwater Res., 6:242-313.

Deflandre, G., and Courteville, 1939. Note préliminaire sur les microfossils des Crétacés du Cambrésis, Bull. Soc. Fr. Microsc., 8:95-106.

Downie, C., Hussain, M. A., and Williams, W. L., 1971. Dinoflagellate cysts and acritarchs association in the Paleogene of south-east England. Geosci. Man., 3:29-35.

Drugg, W. S., 1967. Palynology of the Upper Moreno Formation (Late Cretaceous-Paleogene) Escarpado Canyon, California. Palaeontographica B, 120:1-71.

Edgell, H. S., 1964. The correlative value of microplankton in the Cretaceous of the Perth Basin, W. A. Annu. Rep. Geol. Surv. W. Aust., 1963:55-57.

Evans, P. R., 1966. Mesozoic stratigraphy palynology in Australia. Australas. Oil Gas Rev., 12:58-63.

Firth, J. V., 1987. Dinoflagellate biostratigraphy of the Maestrichtian to Danian interval in the U. S. Geological Survey Albany core, Georgia, U.S.A. Palynology, 11:199-216.

Goodman, D. K., 1979. Dinoflagellate "communities" from the Lower Eocene Nanjemoy Formation of Maryland, U.S.A. Palynology, 3:169-190.

Gruas-Cavagnetto, C., 1967. Complex sporo-polliniques du Sparnacien du Bassin de Paris. Rev. Palaeobot. Palynol., 5:243-261. 1968. étude palynologique des divers gisements du Sparnacien du Bassin de Paris. Mem. Soc. Geol. Fr., 47:1-144.
Harker, S. D., and Sarjeant, W.A.S., 1975. The stratigraphic distribution of organic-walled dinoflagellate cysts in the Cretaceous and Tertiary. Rev. Palaeobot. Palynol., 20:217-315.

Harland, R., 1973. Dinoflagellate cysts and acritarchs from the Bearpaw Formation (Upper Campanian) of southern Alberta, Canada. Palaeontology, 16:665-706.

1983. Distribution maps of Recent dinoflagellate cysts in bottom sediments from North Atlantic Ocean and adjacent seas. Palaeontology, 26:321-387.

Helby, R., Morgan, R., and Partridge, A. D., 1987. A palynological zonation of the Australian Mesozoic. In Jell, P. A. (Ed.), Studies in Australian Mesozoic Palynology. Mem. Assoc. Australas. Palaeontol., 4:1-85.

Ioannides, N. S., 1986. Dinoflagellate cysts from Upper CretaceousLower Tertiary sections, Bylot and Devon islands, Arctic Archipelago. Bull. Geol. Surv. Can., 371:1-99.

Lentin, J. K., and Manum, S. B., 1986. A new peridinioid dinoflagellate from Campanian sediments recovered from DSDP Leg 22, Site 217, Indian Ocean. Palynology, 10:111-116.

Lentin, J. K., and Williams, G. L., 1976. A monograph of fossil peridinioid cysts. Bedford Inst. Oceanogr. Rep. Ser., No. BI-7516.

1977. Fossil dinoflagellates: index to genera and species, 1977 edition. Bedford Inst. Oceanogr. Rep. Ser., No. BI-R-77-8. 1980. Dinoflagellate provincialism, with emphasis on Campanian Peridiniaceans. Am. Assoc. Stratigr. Palynol. Contrib. Ser., 7:1-46.

1989. Fossil dinoflagellates: index to genera and species, 1989 edition. Am. Assoc. Stratigr. Palynol. Contrib. Ser., 20:1473.

Manum, S. B., and Cookson, I. C., 1964. Cretaceous microplankton in a sample from Graham Island, Arctic Canada, collected during the second "Fram"-Expedition (1898-1902). With notes on microplankton from the Hassel Formation, Ellef Ringnes Island. Schr. utgitt av Det Norske Videnskaps-Akademi Oslo I MatNaturv. Klasse, 17:1-35.

Mao, S.-Z., and Norris, G., 1988. Late Cretaceous-Early Tertiary dinoflageliates and acritarchs from the Kashi Area, Tarim Basin, Xiniang Province, China. R. Ontario Mus. Life Sci. Contrib., 150:1-93

Marheinecke, U., 1986. Dinoflagellaten des Maastrichtian der Grube Hemmoor (Niedersachsen), Geol. Jahrb. Reihe A, Heft, 93:3-93.

Marshall, N. G., 1990. Campanian dinoflagellates from southern Australia. Alcheringa, 14:1-38.

May, F. E., 1980. Dinoflagellate cysts of the Gymnodiniaceae, Peridiniaceae and Gonyaulacaceae from the Upper Cretaceous Monmouth Group, Atlantic highlands, New Jersey. Palaeontographica $B, 172: 10-116$

McIntyre, D. J., 1974. Palynology of an Upper Cretaceous section, Horton River, District of Mackenzie, Northwest Territory. Pap.Geol. Surv. Can., No. 74-14.

1975. Morphologic changes in Deflandrea from a Campanian section, District of Mackenzie, North West Territory, Canada. Geosci. Man., 11:61-76.

Morgan, R., 1977. Elucidation of the Cretaceous dinoflagellate Diconodinium Eisenack and Cookson, 1960, and related peridinioid species from Australia. Palynology, 1:123-137.

Roberts, B. H., 1980. Organic-walled microplankton from the Upper Moreville Chalk and basal Demopolis Chalk (Upper Cretaceous) from eastern Mississippi and west-central Alabama [MS thesis]. Virginia Polytechnic Inst.

Rossignol, M., 1961. Analyse pollinique de sédiments marins Quaternaires en Israel. I: sédiments Récents. Pollen et Spores, 3:303324.

1962. Analyse pollinique de sédiments marins Quaternaires en Israel. II. sédiments Pléistocènes. Pollen et Spores, 4:121-148.

Scotese, C. R., Royer, J. Y., Mueller, R. D., Nurnberg, D., Mayes, C. L., Lawver, L. A., Tomling, R. L., Newman, J. S., Heubeck, C. E., Winn, J. K., Beckly, L., and Sclater, J. G., 1978. Atlas of Mesozoic and Cenozoic Plate Tectonic Reconstructions. Paleoceanographic mapping project, Inst. for Geophys., Univ. of Texas, Tech. Rep., No. 90. 
Scull, G. J., Felix, C. J., McCaleb, S. B., and Shaw, W. G., 1966. The interdiscipline approach to palaeoenvironmental interpretations. Trans. Gulf Coast Assoc. Geol. Soc., 16: 81-117.

Shipboard Scientific Party, 1989. Site 748. In Schlich, R., Wise, S. W., Jr., et al., Proc. ODP, Init. Repts., 120: College Station, TX (Ocean Drilling Program), 157-235.

Stover, L. E., and Evitt, W. R., 1978. Analyses of pre-Pleistocene organic-walled dinoflagellates. Stanford Univ. Publ. Geol. Sci., $15: 1-300$.

Stover, L. E., and Williams, G. L., 1982. Dinoflagellates. Proc. 3rd N. Am. Paleontol. Conv., 2:525-533.

1987. Analyses of Mesozoic and Cenozoic organic-walled dinoflagellates 1977-1985. Am. Assoc. Stratigr. Palynol. Contrib. Ser., 18:1-243.

Vozzhennikova, T. F., 1965. Introduction to the study of fossi peridinian algae. Moscow, Nauka Publishers. (in Russian)

1967. Fossil peridinians from Jurassic, Cretaceous and Paleogene deposits of the USSR. Moscow, Nauka Publishers. (in Russian)

1979. Dinocysts and their stratigraphic significance. Novosibirsk, Nauka Publishers/Proc. Inst. Geol. Geophys., Siberian Branch of USSR Acad. Sci., No. 422. (in Russian)

Wall, D., 1967. Fossil microplankton in deep sea cores from the Caribbean Sea. Palaeontology, 10:95-123.
Wall, D., and Dale, B., 1968. Early Pleistocene dinoflagellates from the Royal Society borehole at Ludham, Norfolk. New Phytol. 67:315-326.

Wall, D., Dale, B., Lohmann, G. P., and Smith, W. K., 1977. The environmental and climatic distribution of dinoflagellate cysts in modern marine sediments from regions in the North and South Atlantic Oceans and adjacent seas. Mar. Micropaleontol., 2:121200.

Williams, G. L., and Bujak, J. P., 1977. Distribution pattern of some North Atlantic Cenozoic dinoflagellates cysts. Mar. Micropaleontol., 2:223-233.

1985. Mesozoic and Cenozoic dinoflagellates. In Bolli, H. Saunders, J. B., and Perch-Nielsen, K. (Eds.), Plankton Stratigraphy: Cambridge (Cambridge Univ. Press), 847-964.

Wilson, G. J., 1974. Campanian and Maestrichtian dinoflagellate cysts from the Maestricht region and Denmark [Ph.D. dissert.]. Nottingham Univ., U. K.

1984. Some new dinoflagellate species from the New Zealand Haumurian and Piropauan Stages (Santonian-Maestrichtian, Late Cretaceous). N. Z. J. Bot., 22:549-556.

Date of initial receipt: 5 April 1990

Date of acceptance: 25 January 1991

Ms 120B-190 


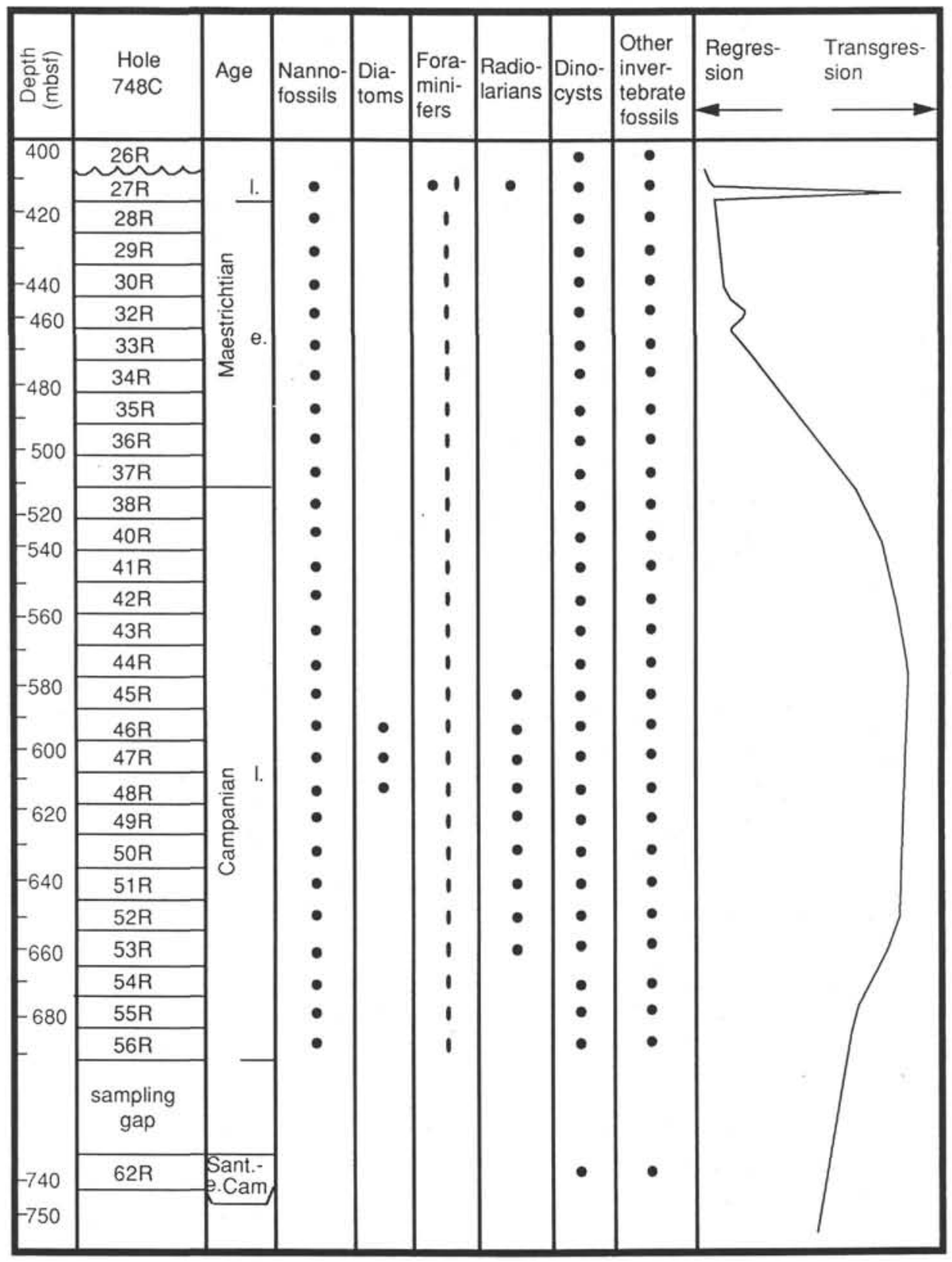

Figure 8. Vertical distribution of various fossil groups through the studied interval and the assumed course of transgression/regression during the ?Santonian-Campanian to Maestrichtian, based mainly on the fossils. For the foraminifers the round symbol represents planktonic, the oval benthic. 


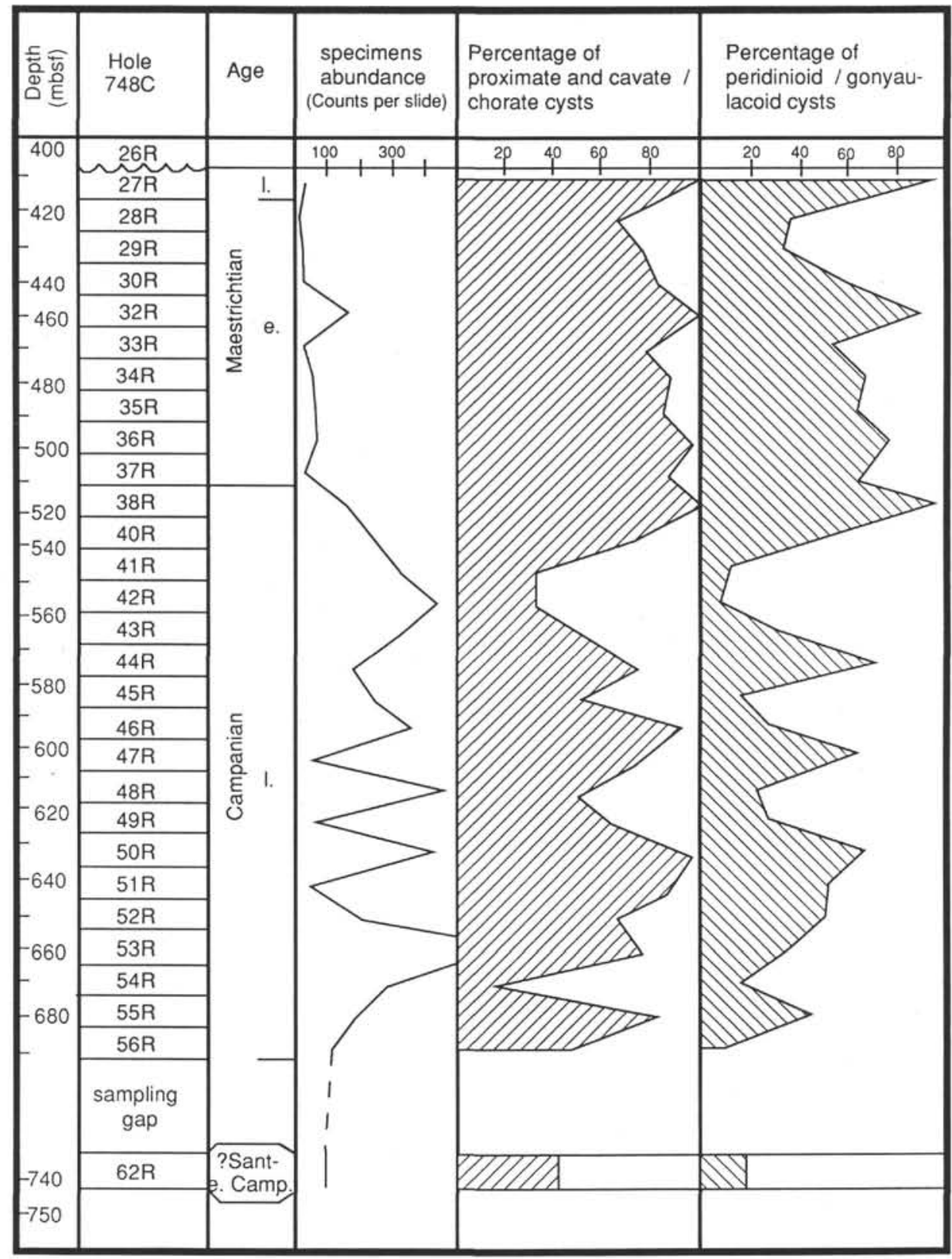

Figure 9. Variation in dinocyst specimen abundance and different types of dinocysts in the studied interval. 

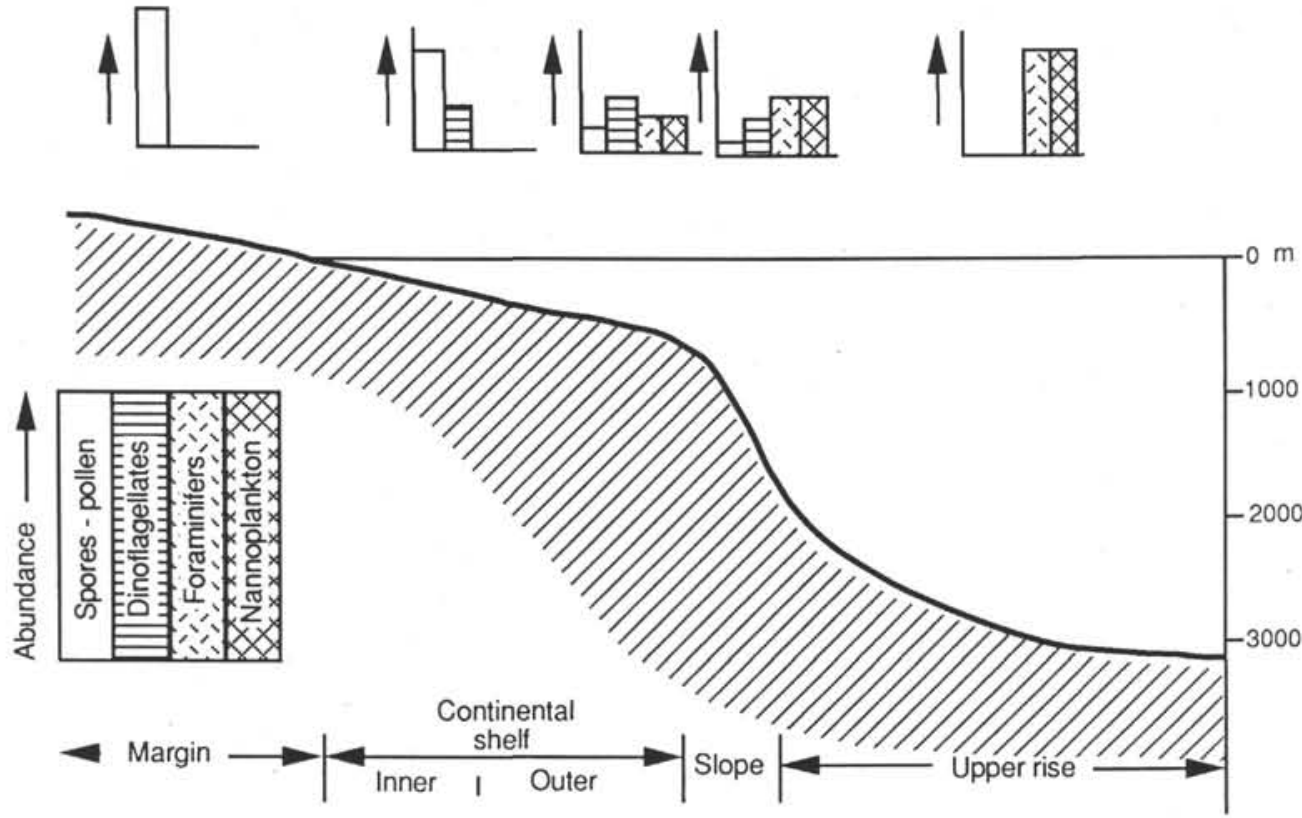

Figure 10. Relative distribution patterns of spores and pollen, dinoflagellates, foraminifers, and nannoplankton in various paleoenvironments (from Stover and Williams, 1982).

Table 3. The main features of Campanian to Maestrichtian dinocyst assemblages from different parts of the world.

\begin{tabular}{|c|c|c|c|c|}
\hline $\begin{array}{l}\text { Name of } \\
\text { area or } \\
\text { country }\end{array}$ & $\begin{array}{l}\text { Age of } \\
\text { dinocyst } \\
\text { assembs. }\end{array}$ & Characters of dinocyst assemblages & Source of data & Province \\
\hline $\begin{array}{l}\text { Arctic } \\
\text { Canada }\end{array}$ & $\begin{array}{l}\text { Santonian- } \\
\text { Maestrich- } \\
\text { tian }\end{array}$ & $\begin{array}{l}\text { Dominated by peridinioid cysts, with } \\
\text { abundant specimens and diverse species of } \\
\text { Chatangiella Diconodinium, Spinidinium and } \\
\text { other cavate cysts present. }\end{array}$ & $\begin{array}{l}\text { loannides, } \\
1986\end{array}$ & $\begin{array}{l}\text { North Pacific } \\
\text { cool- } \\
\text { temperate } \\
\text { Mcintyre suite }\end{array}$ \\
\hline $\begin{array}{l}\text { New } \\
\text { Jersey } \\
\text { U.S.A. }\end{array}$ & $\begin{array}{l}\text { Campanian } \\
\quad \text { to } \\
\text { Maestrich- } \\
\text { tian } \\
\end{array}$ & $\begin{array}{l}\text { More peridinioid cysts than chorate cysts, but } \\
\text { with diverse species of Spiniferites. Among } \\
\text { peridinioid cysts, Isabelidinium are more } \\
\text { common than Chatangiella. }\end{array}$ & $\begin{array}{l}\text { Aurisano, } \\
1989\end{array}$ & $\begin{array}{l}\text { North Atlantic } \\
\text { warm- } \\
\text { temperate } \\
\text { Williams suite }\end{array}$ \\
\hline $\begin{array}{l}\text { Georgia, } \\
\text { U.S.A. }\end{array}$ & $\begin{array}{l}\text { Maestrich- } \\
\text { tian to } \\
\text { Danian }\end{array}$ & $\begin{array}{l}\text { Spiniferites and Exochosphaeridium } \\
\text { abundant, diverse species of Spiniferites } \\
\text { and other chorate cysts. Isabelidinium, } \\
\text { Xenikoon and Andalusiella present. }\end{array}$ & $\begin{array}{l}\text { Firth, } \\
1987\end{array}$ & \multirow{3}{*}{$\begin{array}{l}\text { ? Probably } \\
\text { transitional } \\
\text { from } \\
\text { temperate } \\
\text { to } \\
\text { subtropical }\end{array}$} \\
\hline $\begin{array}{l}\text { West- } \\
\text { central } \\
\text { Alabama } \\
\text { and east } \\
\text { Mississipp }\end{array}$ & Campanian & $\begin{array}{l}\text { More diverse chorate genera, such as } \\
\text { Achomosphaera, Florentinia, Hystrichosphaeri- } \\
\text { dium and Spiniferites. High species diversity of } \\
\text { Spiniferites. Chatangiella and Isabelidinium } \\
\text { present. }\end{array}$ & $\begin{array}{l}\text { Roberts, } \\
1980\end{array}$ & \\
\hline $\begin{array}{l}\text { Hemmoor. } \\
\text { northwest } \\
\text { Germany }\end{array}$ & $\begin{array}{l}\text { Maestrich- } \\
\text { tian }\end{array}$ & $\begin{array}{l}\text { Dominated by chorate and spiniferate cysts, } \\
\text { mainly Spiniferites ramosus, with minor } \\
\text { Chatangiella, Isabelidinium. Cerodinium } \\
\text { and Deflandrea present. }\end{array}$ & $\begin{array}{l}\text { Marheinecke, } \\
1986\end{array}$ & \\
\hline Australia & Senonian & $\begin{array}{l}\text { Dominated by peridinioid cysts, characterized } \\
\text { by the presence of Amphidiadema, Nelsoniella, } \\
\text { and Xenikoon. Chatangiella also present. }\end{array}$ & $\begin{array}{l}\text { Cookson and Eisenack, } \\
1960\end{array}$ & \multirow{5}{*}{$\begin{array}{l}\text { South Indian } \\
\text { cool- } \\
\text { temperate } \\
\text { Helby suite }\end{array}$} \\
\hline $\begin{array}{l}\text { south- } \\
\text { western } \\
\text { Victoria, } \\
\text { Australia }\end{array}$ & Senonian & $\begin{array}{l}\text { Dominated by peridinioid cysts, with abundant } \\
\text { Isabelidinium, particular I. cretaceum and } \\
\text { I. belfastense. Amphidiadema denticulata and } \\
\text { Odontochitina porifera present. }\end{array}$ & $\begin{array}{l}\text { Cookson and } \\
\text { Eisenack, } 1961 .\end{array}$ & \\
\hline Australia & $\begin{array}{l}\text { Upper } \\
\text { Mesozoic } \\
\text { (Senonian) } \\
\end{array}$ & $\begin{array}{l}\text { Dominated by species of Isabelidinium, } \\
\text { Chatangiella, Nelsoniella and other } \\
\text { peridinioid cysts. }\end{array}$ & $\begin{array}{l}\text { Cookson and } \\
\text { Eisenack, 1974, } 1982 .\end{array}$ & \\
\hline $\begin{array}{l}\text { northern } \\
\text { Antarctic } \\
\text { Peninsula }\end{array}$ & $\begin{array}{l}\text { late Campa- } \\
\text { nian to } \\
\text { Paleocene }\end{array}$ & $\begin{array}{l}\text { Abundant cysts of I. cretaceum, Deflandrea, } \\
\text { Cerodinium, Spinidinium, and } \\
\text { Manumiella. }\end{array}$ & Askin, 1988 & \\
\hline $\begin{array}{l}\text { Kerguelen } \\
\text { Plateau, } \\
\text { southern } \\
\text { Indian } \\
\text { Ocean }\end{array}$ & $\begin{array}{l}\text { Campanian } \\
\text { to } \\
\text { Maestrich- } \\
\text { tian }\end{array}$ & $\begin{array}{l}\text { Dominated by peridinioid cysts, with diverse } \\
\text { species of Chatangiella. Isabelidinium, and } \\
\text { Nelsoniella. Amphidiadema, Cerodinium, } \\
\text { Satyrodinium and Xenikoon present. Areoligera, } \\
\text { Circulodinium distinctum and Heterosphaeridium } \\
\text { common. }\end{array}$ & $\begin{array}{l}\text { This paper, } \\
1991\end{array}$ & \\
\hline
\end{tabular}




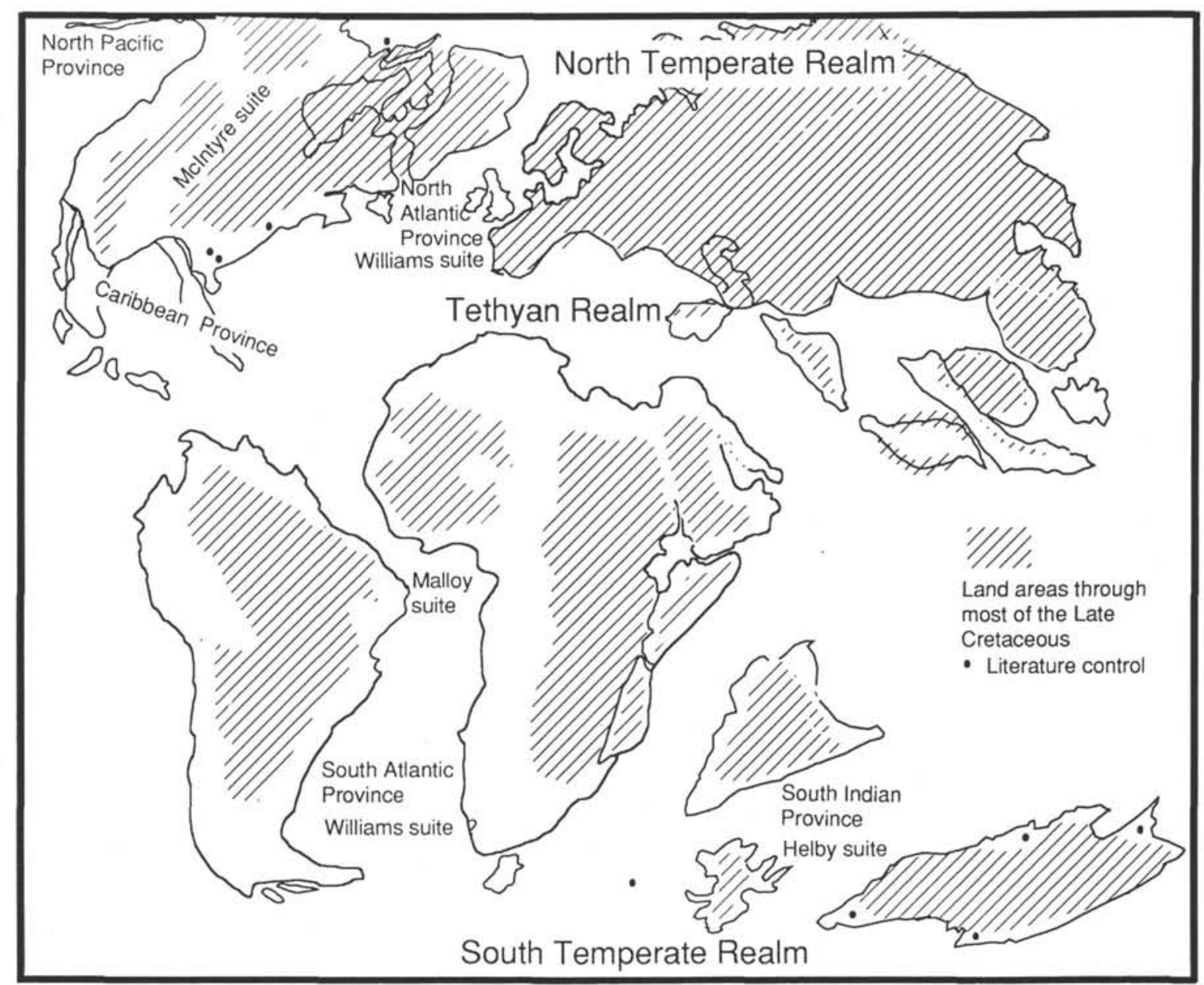

Figure 11. Campanian (to Maestrichtian) biogeographic map, based on Scotese et al. (1987), Lentin and Williams (1980), and information from this paper. 


\section{APPENDIX A}

\section{Dinoflagellate Cysts from Hole 748C}

Abratopdinium cardioforme n. sp. (Plate 1, Figs. 3-4)

Abratopdinium kerguelense $\mathrm{n}$. sp. (Plate 1, Figs. 1-2 and 6)

Achomosphaera ramulifera (Deflandre, 1937) Evitt, 1963

Achomosphaera sp.

Alterbidinium acutulum (Wilson, 1967) Lentin and Williams, 1985. (Plate 4, Fig. 4)

Alterbidinium minus (Alberti, 1959) Lentin and Williams, 1985. (Plate 9, Fig. 11)

Alterbidinium sp.

Amphidiadema denticulata Cookson and Eisenack, 1960a. (Plate 3, Figs. 6-7)

Amphidiadema sp. (Plate 3, Fig. 1)

Amphorosphaeridium fenestratum Davey, 1969

Amphorosphaeridium sp.

Apteodinium maculatum Eisenack and Cookson, 1960

Areoligera coronata (Wetzel, 1933) Lejeune-Carpenter, 1938

Areoligera senonensis Lejeune-Carpenter, 1938. (Plate 8, Fig. 1)

Areoligera sp.

Areoligera sp. cf. A. senonensis Lejeune-Carpenter, 1938. (Plate 8, Fig. 7)

Balteocysta perforata (Davey, 1978) Wilson and Clowes, 1980

Batiacasphaera sp.

Bulbodinium seitzii Wetzel, 1960

Callaiosphaeridium asymmetricum (Deflandre and Courteville, 1939) Davey and Williams, 1966

Canningia kukebaiensis Mao and Norris, 1988

Canningia reticulata Cookson and Eisenack, 1960. (Plate 7, Fig. 10)

Canningia senonica Clarke and Verdier, 1967

Canningia sp. (Plate 9, Fig. 2)

Canningia sp. cf. C. reticulata Cookson and Eisenack, 1960

Canningia sp. cf. C. scabrosa Cookson and Eisenack, 1970

Canninginopsis colliveri (Cookson and Eisenack, 1960) Backhouse, 1988

Cannosphaeropsis utinensis Wetzel, 1933

Cassiculosphaeridia reticulata Davey, 1969

Cerodinium diebelii (Alberti, 1959) Lentin and Williams, 1987. (Plate 3, Fig. 10)

Chatangiella? biapertura (McIntyre, 1975) Lentin and Williams, 1976

Chatangiella ditissima (McIntyre, 1975) Lentin and Williams, 1976. (Plate 3, Fig. 9)

Chatangiella granulifera (Manum, 1963) Lentin and Williams, 1976

Chatangiella serratula (Cookson and Eisenack, 1958) Lentin and Williams, 1976. (Plate 4, Fig. 6)

Chatangiella sp.

Chatangiella spectabilis (Alberti, 1959) Lentin and Williams, 1976. (Plate 3, Fig. 2)

Chatangiella tripartita (Cookson and Eisenack, 1960) Lentin and Williams, 1976. (Plate 3, Fig. 12; Plate 4, Fig. 7)

Chatangiella verrucosa (Manum, 1963) Lentin and Williams, 1976. (Plate 3, Fig. 13)

Chatangiella victoriensis (Cookson and Manum, 1964) Lentin and Williams, 1976. (Plate 4, Fig. 1)

Chlamydophorella discreta Clarke and Verdier, 1967. (Plate 6, Fig. 4)

Chlamydophorella nyei Cookson and Eisenack, 1958

Circulodinium distinctum (Deflandre and Cookson, 1955) Jansonius, 1986. (Plate 7, Fig. 5; Plate 9, Fig. 3)

Circulodinium distinctum subsp. longispinatum (Davey, 1978) Lentin and Williams, 1989. (Plate 7, Figs. 1 and 8)

Cleistosphaeridium? aciculare Davey, 1969

Cleistosphaeridium armatum (Deflandre, 1937) Davey, 1969

Cleistosphaeridium? flexuosum Davey et al., 1966

Cleistosphaeridium huguoniotii (Valensi, 1955) Davey, 1969

Cleistosphaeridium? multifurcatum (Deflandre, 1937) Davey et al., 1969

Cleistosphaeridium sp.

Cordosphaeridium sp.

Coronifera sp. cf. C. striolata (Deflandre, 1937) Stover and Evitt, 1978

Cyclonephelium brevispinatum (Millioud, 1969) Below, 1981

Cyclonephelium compactum Deflandre and Cookson, 1955. (Plate 7, Figs. 2 and 6)
Cyclonephelium crassimarginatum Cookson and Eisenack, 1974. (Plate 7, Fig. 9; Plate 9, Fig. 1)

Cyclonephelium hughesii Clarke and Verdier, 1967

Cyclonephelium paucimarginatum Cookson and Eisenack, 1962

Cyclopsiella sp.

Deflandrea sp.

Diconodinium arcticum Manum and Cookson, 1964

Diconodinium psilatum Morgan, 1977

Diconodinium? rhombiforme Vozzhennikova, 1967

Diconodinium sp. (Plate 3, Fig. 4)

Diconodinium sp. cf. D. arcticum Manum and Cookson, 1964. (Plate 4, Fig. 3)

Dinogymnium albertii Clarke and Verdier, 1967. (Plate 4, Fig. 14)

Dinogymnium curvatum (Vozzhennikova, 1967) Lentin and Williams, 1973

Dinogymnium digitus (Deflandre, 1935) Evitt et al., 1967. (Plate 1, Fig. 5)

Dinogymnium sp.

Dinogymnium undulosum Cookson and Eisenack, 1970. (Plate 11, Fig. 2)

Dinogymnium westralium (Cookson and Eisenack, 1958) Evitt et al., 1967

Elytrocysta druggii Stover and Evitt, 1978. (Plate 5, Figs. 12-13; Plate 9, Fig. 10)

Endoceratium sp.

Escharisphaeridia sp. (Plate 5, Fig. 9)

Eucladinium gambangense (Cookson and Eisenack, 1970) Stover and Evitt, 1978. (Plate 5, Fig. 1)

Eucladinium madurense (Cookson and Eisenack, 1970) Stover and Evitt, 1978. (Plate 5, Fig. 10)

Eucladinium spinosissimum (Cookson and Eisenack, 1970) Stover and Evitt, 1978

Eurydinium ellipticum n. sp. (Plate 2, Figs. 1-2 and 8-9; Plate 10, Fig. 1)

Eurydinium eyrense (Cookson and Eisenack, 1971) Stover and Evitt, 1978

Eurydinium ingramii (Cookson and Eisenack, 1970) Stover and Evitt, 1978. (Plate 3, Fig. 8)

Eurydinium tempestivum Mao and Norris, 1988

Exochosphaeridium arnace Davey and Verdier, 1973

Exochosphaeridium phragmites Davey et al., 1966

Exochosphaeridium sp.

Florentinia sp. cf. F. mantellii (Davey and Williams, 1966) Davey and Verdier, 1973

Fromea chytra (Drugg, 1967) Stover and Evitt, 1978. (Plate 6, Fig. 8)

Fromea sp.

Gillinia hymenophora Cookson and Eisenack, 1960. (Plate 5, Fig. 5)

Gonyaulacysta sp.

Heterosphaeridium conjunctum Cookson and Eisenack, 1968. (Plate 8 , Figs. 4-5 and 8)

Heterosphaeridium cordiforme Yun, 1981

Heterosphaeridium? heteracanthum (Deflandre and Cookson, 1955) Eisenack and Kjellström, 1971. (Plate 8, Fig. 2)

Heterosphaeridium sp. (Plate 8, Fig. 6; Plate 11, Fig. 4)

Hystrichodinium isodiametricum (Cookson and Eisenack, 1958) Stover and Evitt, 1978

Hystrichodinium pulchrum Deflandre, 1935. (Plate 8, Fig. 3)

Hystrichodinium sp.

Hystrichokolpoma sp.

Hystrichosphaeridium tubiferum (Ehrenberg, 1838) Deflandre, 1937

Impagidinium cristatum (May, 1980) Lentin and Williams, 1981

Impagidinium $\mathrm{sp.}$

Isabelidinium acuminatum (Cookson and Eisenack, 1958) Stover and Evitt, 1978. (Plate 3, Fig. 5)

Isabelidinium bakeri (Deflandre and Cookson, 1955) Lentin and Williams, 1977

Isabelidinium belfastense (Cookson and Eisenack, 1961) Lentin and Williams, 1977. (Plate 4, Fig. 5)

Isabelidinium cooksoniae (Alberti, 1959) Lentin and Williams, 1977. (Plate 3, Fig. 3)

Isabelidinium cretaceum cretaceum (Cookson, 1956) Lentin and Williams, 1977. (Plate 1, Fig. 10; Plate 10, Fig. 3; Plate 11, Fig. 6) Isabelidinium cretaceum gravidum n. subsp. (Plate 1, Figs. 11-12) 
Isabelidinium cretaceum oviforme n. subsp. (Plate 1, Figs. 7-9; Plate 10, Fig. 2; Plate 11, Fig. 5)

Isabelidinium korojonense (Cookson and Eisenack, 1958) Lentin and Williams, 1977

Isabelidinium magnum (Davey, 1970) Stover and Evitt, 1978

Isabelidinium microarmum (McIntyre, 1975) Lentin and Williams, 1977. (Plate 3, Fig. 11)

Isabelidinium pellucidum (Deflandre and Cookson, 1955) Lentin and Williams, 1977. (Plate 4, Figs. 8-9)

Isabelidinium $\mathrm{sp}$.

Isabelidinium sp. A (Plate 4, Figs. 11-12)

Isabelidinium thomasii (Cookson and Eisenack, 1961) Lentin and Williams, 1977

Kallosphaeridium? granulatum (Norvick, in Norvick and Burger, 1976) Stover and Evitt, 1978

Kallosphaeridium? helbyi (Cookson and Hughes, 1964) Helby, 1987. (Plate 4, Fig. 13)

Kallosphaeridium? ringnesiorum (Manum and Cookson, 1964) Helby, 1987

Kallosphaeridium sp.

Kiokansium polypes (Cookson and Eisenack, 1962) Below, 1982

Kiokansium sp. cf. K. polypes (Cookson and Eisenack, 1962) Below, 1982

Laciniadinium firmum (Harland, 1973) Morgan, 1977. (Plate 4, Fig. 2)

Laciniadinium williamsii Ioannides, 1986

Lanternosphaeridium sp.

Leberidocysta chlamydata (Cookson and Eisenack, 1962) Stover and Evitt, 1978

Lejeunecysta $\mathrm{sp}$.

Leptodinium sp.

Maduradinium pentagonum Cookson and Eisenack, 1970

Manumiella sp.

Manumiella sp. cf. M. sp. 2 of Askin (1988). (Plate 4, Fig. 10)

Microdinium ornatum Cookson and Eisenack, 1960

Microdinium sp.

Nelsoniella aceras Cookson and Eisenack, 1960. (Plate 5, Figs. 6-7; Plate 11, Fig. 1)

Nelsoniella semireticulata Cookson and Eisenack, 1960

Nelsoniella sp. (Plate 1, Fig. 13)

Nelsoniella tuberculata Cookson and Eisenack, 1960. (Plate 5, Figs. 2-3; Plate 9, Fig. 6)

Nematosphaeropsis sp.

Odontochitina cribropoda Deflandre and Cookson, 1955. (Plate 6, Fig. 2; Plate 10, Fig. 4)

Odontochitina operculata Wetzel, 1933. (Plate 6, Fig. 11)
Odontochitina porifera Cookson, 1956. (Plate 2, Fig. 3; Plate 6, Fig. 1)

Odontochitina sp.

Odontochitina spinosa Wilson, 1984

Oligosphaeridium complex (White, 1842) Davey and Williams, 1966

Oligosphaeridium pulcherrimum (Deflandre and Cookson, 1955) Davey and Williams, 1966. (Plate 7, Fig. 7)

Oligosphaeridium sp.

Palaeocystodinium sp.

Palaeocystodinium sp. cf. P. scabratum Jain et al., 1975. (Plate 2, Fig. 11)

Palaeohystrichophora infusorioides Deflandre, 1935. (Plate 7, Fig. 4)

Palaeohystrichophora sp.

Palaeoperidinium parvum (Harland, 1973) Lentin and Williams, 1976

Paralecaniella sp.

Pierceites schizocystis Habib and Drugg, 1987. (Plate 9, Fig. 7)

Platycystidia diptera Cookson and Eisenack, 1960

Pterodinium cingulatum (Wetzel, 1933) Below, 1981

Satyrodinium bengalense Lentin and Manum, 1986. (Plate 2, Figs. 7 and 10)

Satyrodinium haumuriense (Wilson, 1984) Lentin and Manum, 1986. (Plate 2, Figs. 4-6; Plate 9, Fig. 5)

Senegalinium sp. cf. S.? microgranulatum (Stanley, 1965) Stover and Evitt, 1978

Spinidinium? clavus Harland, 1973. (Plate 9, Fig. 4; Plate 11, Fig. 3)

Spinidinium lanternum Cookson and Eisenack, 1970. (Plate 7, Fig. 3; Plate 9, Fig. 9)

Spinidinium sp. (Plate 11, Fig. 7)

Spinidinium uncinatum May, 1980. (Plate 6, Fig. 3)

Spiniferites ramosus (Ehrenberg, 1838) Loeblich and Loeblich, 1966

Spiniferites sp.

Subtilisphaera pirnaensis (Alberti, 1959) Jain and Millepied, 1973

Subtilisphaera sp.

Talimudinium scissurum Mao and Norris, 1988

Tanyosphaeridium variecalamus Davey and Williams, 1966

Tanyosphaeridium xanthiopyxides (Wetzel, 1933) Stover and Evitt, 1978. (Plate 6, Fig. 7)

Trichodinium castanea (Deflandre, 1935) Clarke and Verdier, 1967

Trichodinium sp.

Trithyrodinium fragile Davey, 1969. (Plate 6, Fig. 5)

Trithyrodinium suspectum (Manum and Cookson, 1964) Davey, 1969. (Plate 6, Fig. 6; Plate 8, Fig. 9; Plate 9, Fig. 8)

Xenascus ceratioides (Deflandre, 1937) Lentin and Williams, 1973. (Plate 6, Figs. 10 and 12; Plate 10, Fig. 5)

Xenikoon australis Cookson and Eisenack, 1960. (Plate 5, Fig. 8)

Xenikoon sp. 


\section{APPENDIX B}

Compiled Ranges of Selected Species

"General" data from Williams and Bujak (1984); specific sources are Harker and Sarjeant (1975) for unnumbered entries; 1 = Aurisano (1989); 2 = Benson (1976); 3 = Firth (1987); 4 = Helby et al. (1987); 5 = Ioannides (1986); 6 = Marheinecke (1986); 7 = May (1980); McIntyre (1975); 9 = Wilson (1974).

\begin{tabular}{|c|c|c|c|c|}
\hline Species & Europe & North America & Australia & General \\
\hline $\begin{array}{l}\text { Alterbidinium } \\
\text { acutulum }\end{array}$ & $\begin{array}{l}\text { early Maestrichtian } \\
\text { (9) }\end{array}$ & $\begin{array}{l}\text { Campanian - Maestrichtian (1), } \\
\text { early Maestrichtian (2), Maes - } \\
\text { trichtian - Danian (3), Campa - } \\
\text { nian - Maestrichtian (7) }\end{array}$ & & \\
\hline $\begin{array}{l}\text { Areoligera } \\
\text { senonensis }\end{array}$ & . & $\begin{array}{l}\text { Maestrichtian, } \\
\text { Santonian - Maestrichtian (1) }\end{array}$ & & $\begin{array}{l}\text { late Campan. - } \\
\text { early Eocene }\end{array}$ \\
\hline $\begin{array}{l}\text { Callaiosphaeridium } \\
\text { asymmetricum }\end{array}$ & $\begin{array}{l}\text { Cenomanian - late } \\
\text { Maestrichtian }\end{array}$ & $\begin{array}{l}\text { Campanian, } \\
\text { Turonian - early Campanian (1). }\end{array}$ & & $\begin{array}{l}\text { Hauterivian - } \\
\text { early } \\
\text { Campanian }\end{array}$ \\
\hline $\begin{array}{l}\text { Cerodinium } \\
\text { diebelii }\end{array}$ & $\begin{array}{l}\text { Coniacian - } \\
\text { Maestrichtian, } \\
\text { Maestrichtian (6). }\end{array}$ & $\begin{array}{l}\text { late Maestrichtian, } \\
\text { Maestrichtlan (1), (5), (7) }\end{array}$ & $\begin{array}{l}\text { late Campanian - } \\
\text { basal Danian (4) }\end{array}$ & $\begin{array}{l}\text { late Cam- } \\
\text { panian, early } \\
\text { Paleocene }\end{array}$ \\
\hline $\begin{array}{l}\text { Chatangiella } \\
\text { ditissima }\end{array}$ & & Santontan - Maestrichtian (8) & & \\
\hline $\begin{array}{l}\text { Chatangiella } \\
\text { granulifera }\end{array}$ & Santonian & $\begin{array}{l}\text { late Campanian, } \\
\text { late Santonlan (1), } \\
\text { Santonian - Maestrichtian (5) }\end{array}$ & & $\begin{array}{l}\text { Coniacian - } \\
\text { Campanian }\end{array}$ \\
\hline $\begin{array}{l}\text { Chatangiella } \\
\text { serratula }\end{array}$ & & 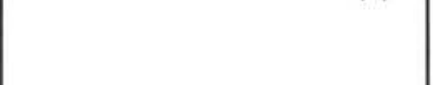 & $\begin{array}{l}\text { late Coniacian - } \\
\text { early Maestrichtian }\end{array}$ & \\
\hline $\begin{array}{l}\text { Chatangiella } \\
\text { spectabilis }\end{array}$ & Coniacian & $\begin{array}{l}\text { late Campanian, } \\
\text { Santonian - Maestrichtian (5) }\end{array}$ & & \\
\hline $\begin{array}{l}\text { Chatangiella } \\
\text { tripartita }\end{array}$ & $\begin{array}{l}\text { Campanian - early } \\
\text { Maestrichtian }\end{array}$ & $\begin{array}{l}\text { late Cenomanian - early } \\
\text { Maestrichtian, } \\
\text { late Santonian - Campanian (1) }\end{array}$ & $\begin{array}{l}\text { Cenomanian - } \\
\text { Coniacian, } \\
\text { early Santonian (4) }\end{array}$ & \\
\hline $\begin{array}{l}\text { Chatangiella } \\
\text { verrucosa }\end{array}$ & & $\begin{array}{l}\text { late Cenomanian - early } \\
\text { Maestrichtian, Santonian - } \\
\text { Maestrichtian (5) }\end{array}$ & $\begin{array}{l}\text { late Santonian - } \\
\text { early Campanian }\end{array}$ & \\
\hline $\begin{array}{l}\text { Chatangiella } \\
\text { victoriensis }\end{array}$ & $\begin{array}{l}\text { Coniacian - } \\
\text { Santonian }\end{array}$ & Santonian - Maestrichtian (1) & $\begin{array}{l}\text { Santonian - early } \\
\text { Campanian (4) }\end{array}$ & $\begin{array}{l}\text { Coniacian - } \\
\text { early } \\
\text { Maestrichtian }\end{array}$ \\
\hline $\begin{array}{l}\text { Chlamydophorella } \\
\text { discreta }\end{array}$ & . & Santonian - Maestrichtian (1) & & \\
\hline $\begin{array}{l}\text { Circulodinium } \\
\text { distinctum }\end{array}$ & $\begin{array}{l}\text { Cenomanian - early } \\
\text { Maestrichtian, } \\
\text { Maestrichtian (9) }\end{array}$ & $\begin{array}{l}\text { Cenomanian -Campanian, } \\
\text { Cenomanian - Maestrichtian } \\
\text { (1), late Maestrichtian (2),(3), } \\
\text { Santonian - Maestrichtian (5) }\end{array}$ & $\begin{array}{l}\text { Cenomanian - early } \\
\text { Campanian }\end{array}$ & $\begin{array}{l}\text { late } \\
\text { Kimmeridgian } \\
\text { - Maestrichtian }\end{array}$ \\
\hline $\begin{array}{l}\text { Diconodinium } \\
\text { arcticum }\end{array}$ & Santonian & $\begin{array}{l}\text { late Cenomanian - late } \\
\text { Campanian, Santonian - } \\
\text { Maestrichtian (5) }\end{array}$ & & \\
\hline $\begin{array}{l}\text { Dinogymnium } \\
\text { albertil }\end{array}$ & $\begin{array}{l}\text { Santonian - late } \\
\text { Maestrichtian }\end{array}$ & $\begin{array}{l}\text { late Campanian, } \\
\text { Santonlan - Maestrichtian (1). }\end{array}$ & & \\
\hline $\begin{array}{l}\text { Dinogymnium } \\
\text { digitus }\end{array}$ & Santonian & early Maestrichtian & Coniacian & \\
\hline $\begin{array}{l}\text { Dinogymnium } \\
\text { westralium }\end{array}$ & $\begin{array}{l}\text { late Campanian - } \\
\text { early Maestrichtian }\end{array}$ & $\begin{array}{l}\text { Maestrichtian, } \\
\text { Maestrichtian - Danian (3) }\end{array}$ & $\begin{array}{l}\text { Turonian - early Maes- } \\
\text { trichtian, Santonian - } \\
\text { basal Danian (4) }\end{array}$ & \\
\hline $\begin{array}{l}\text { Exochosphaeridium } \\
\text { phragmites }\end{array}$ & $\begin{array}{l}\text { Cenomanian - late } \\
\text { Campanian }\end{array}$ & $\begin{array}{l}\text { Turonian - Campanian, } \\
\text { Cenomanlan - Maestrichtian (1) }\end{array}$ & $\begin{array}{l}\text { Cenomanian - } \\
\text { Coniacian }\end{array}$ & \\
\hline Fromea chytra & & Maestrichtian (5) & $\begin{array}{l}\text { Santonian - basal } \\
\text { Danian (4). }\end{array}$ & \\
\hline $\begin{array}{l}\text { Gillinla } \\
\text { hymenophora }\end{array}$ & & $\begin{array}{l}\text { Campanian-Maestrichtian (1), } \\
\text { Santonian-Maestrichtian (5) }\end{array}$ & $\begin{array}{l}\text { Cenomanian - Cam- } \\
\text { panian, Santonian - } \\
\text { early Campanian (4) }\end{array}$ & \\
\hline
\end{tabular}




\begin{tabular}{|c|c|c|c|c|}
\hline $\begin{array}{l}\text { Heterosphaeridium } \\
\text { conjunctum }\end{array}$ & & & $\begin{array}{l}\text { late Coniacian - } \\
\text { early Campanian }\end{array}$ & \\
\hline $\begin{array}{l}\text { Heterosphaeridium } \\
\text { ?heteracanthum }\end{array}$ & & & $\begin{array}{l}\text { late Coniacian - } \\
\text { late Maestrichtian }\end{array}$ & \\
\hline $\begin{array}{l}\text { Isabelidinium } \\
\text { acuminatum }\end{array}$ & $\begin{array}{l}\text { Cenomanian - } \\
\text { Santonian }\end{array}$ & $\begin{array}{l}\text { Cenomanian - early Maes - } \\
\text { trichtian, late Turonian - } \\
\text { Santonian (1), Santonian - } \\
\text { Maestrichtian (5) }\end{array}$ & $\begin{array}{l}\text { Cenomanian - } \\
\text { Coniacian }\end{array}$ & $\begin{array}{l}\text { Santonian - } \\
\text { Maestrichtian } \\
\text { late Turonian - }\end{array}$ \\
\hline $\begin{array}{l}\text { Isabelldinium } \\
\text { belfastense }\end{array}$ & $\begin{array}{l}\text { Campanian - } \\
\text { Maestrichtian }\end{array}$ & & $\begin{array}{l}\text { Conlacian, } \\
\text { late Santonian (4) }\end{array}$ & Maestrichtian \\
\hline $\begin{array}{l}\text { Isabelidinium } \\
\text { cooksoniae }\end{array}$ & $\begin{array}{l}\text { Coniacian - } \\
\text { Maestrichtian, } \\
\text { Maestrichtian (6) }\end{array}$ & $\begin{array}{l}\text { Cenomanian - Maestrichtian, } \\
\text { Sentonlan - early Maestrich- } \\
\text { tian (1), Maestrichtian (2), } \\
\text { Campanian - Maestrichtian (7) }\end{array}$ & & $\begin{array}{l}\text { Turonian - } \\
\text { Maestrichtian }\end{array}$ \\
\hline $\begin{array}{l}\text { Isabelidinium } \\
\text { cretaceum }\end{array}$ & late Maestrichtian & $\begin{array}{l}\text { late Maestrichtian, } \\
\text { Maestrichtian (5) }\end{array}$ & $\begin{array}{l}\text { middle Santonian - } \\
\text { early Maestrichtian (4) }\end{array}$ & Maestrichtian \\
\hline $\begin{array}{l}\text { Isabelidinium } \\
\text { korojonense }\end{array}$ & & late Campanian & $\begin{array}{l}\text { late Campanian - early } \\
\text { Maestrichtian, middle } \\
\text { Campanian - early } \\
\text { Maestrichtiasn (4) }\end{array}$ & \\
\hline $\begin{array}{l}\text { Isabelidinlum } \\
\text { pellucidum }\end{array}$ & & & $\begin{array}{l}\text { Campanian - Maestrich- } \\
\text { tian, late Campanian - } \\
\text { Maestrichtian (4) }\end{array}$ & \\
\hline $\begin{array}{l}\text { Nelsoniella } \\
\text { aceras }\end{array}$ & & & $\begin{array}{l}\text { Turonian - early } \\
\text { Maestrichtian, } \\
\text { late Santonian - early } \\
\text { Campanian (4) }\end{array}$ & \\
\hline $\begin{array}{l}\text { Nelsoniella } \\
\text { tuberculata }\end{array}$ & & & $\begin{array}{l}\text { Turonian - Campanian, } \\
\text { late Santonia - early } \\
\text { Campanian (4) }\end{array}$ & \\
\hline $\begin{array}{l}\text { Odontochitina } \\
\text { cribropoda }\end{array}$ & Coniacian & & $\begin{array}{l}\text { Turonian - early } \\
\text { Maestrichtian }\end{array}$ & \\
\hline $\begin{array}{l}\text { Odontochitina } \\
\text { operculata }\end{array}$ & $\begin{array}{l}\text { Cenomanian - } \\
\text { Maestrichtian }\end{array}$ & $\begin{array}{l}\text { Cenomanian - early Campa- } \\
\text { nian, Turonian - Campanian (1), } \\
\text { Santonian - Maestrichtian (5) }\end{array}$ & $\begin{array}{l}\text { Cenomanian - early } \\
\text { Maestrichtian }\end{array}$ & $\begin{array}{l}\text { Barremian - } \\
\text { early } \\
\text { Maestrichtian }\end{array}$ \\
\hline $\begin{array}{l}\text { Odontochitina } \\
\text { porifera }\end{array}$ & & & $\begin{array}{l}\text { early Santonian -early } \\
\text { Campaniannm (4) }\end{array}$ & $\begin{array}{l}\text { Coniacian - } \\
\text { early } \\
\text { Santonian }\end{array}$ \\
\hline $\begin{array}{l}\text { Oligosphaeridium } \\
\text { pulcherrimum }\end{array}$ & $\begin{array}{l}\text { Cenomanian - } \\
\text { Santonian }\end{array}$ & $\begin{array}{l}\text { Cenomanian - Campanian, } \\
\text { late Maestrichtian - Danian (3) }\end{array}$ & $\begin{array}{l}\text { Cenomanian - early } \\
\text { Campanian }\end{array}$ & $\begin{array}{l}\text { Kimmeridgian } \\
\text { - early } \\
\text { Turonian }\end{array}$ \\
\hline $\begin{array}{l}\text { Palaeohystricho- } \\
\text { phora } \\
\text { infusorioides }\end{array}$ & $\begin{array}{l}\text { Cenomanian - } \\
\text { Santonian }\end{array}$ & $\begin{array}{l}\text { Cenomanian - early } \\
\text { Maestrichtian, Santonian - } \\
\text { Maestrichtian (5) }\end{array}$ & $\begin{array}{l}\text { Cenomanian - } \\
\text { Campanian, } \\
\text { Cenomanian - basal } \\
\text { Danian (4) }\end{array}$ & $\begin{array}{l}\text { late Albian - } \\
\text { Campanian }\end{array}$ \\
\hline $\begin{array}{l}\text { Trithyrodinium } \\
\text { suspectum }\end{array}$ & & $\begin{array}{l}\text { Cenomanian, Santonian - early } \\
\text { Maestrichtian (1), Santonian - } \\
\text { Maestrichtian (5) }\end{array}$ & & $\begin{array}{l}\text { late } \\
\text { Cenomanian }\end{array}$ \\
\hline $\begin{array}{l}\text { Xenascus } \\
\text { ceratioides }\end{array}$ & $\begin{array}{l}\text { Cenomanian - } \\
\text { Turonian }\end{array}$ & $\begin{array}{l}\text { Cenomanian - early } \\
\text { Maestrichtian (1), } \\
\text { Santonian - Maestrichtian (5) }\end{array}$ & & $\begin{array}{l}\text { late Albian } \\
\text {-early } \\
\text { Maestrichtian }\end{array}$ \\
\hline Xenikoon australis & & Maestrichtian (2), (3) & $\begin{array}{l}\text { Turonian - late } \\
\text { Campanian, } \\
\text { early Campanian (4) }\end{array}$ & \\
\hline
\end{tabular}




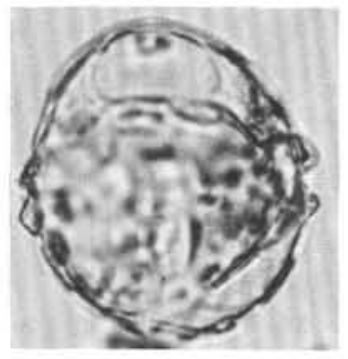

1

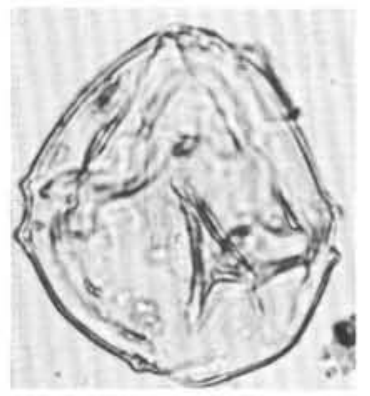

6

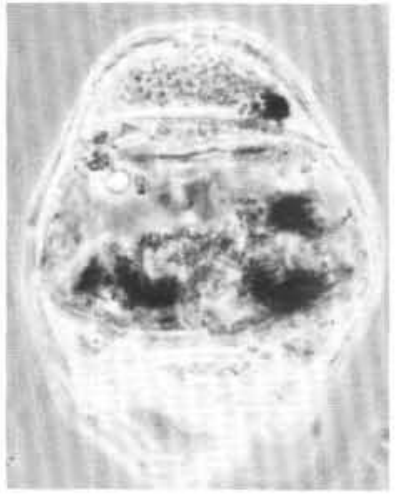

10

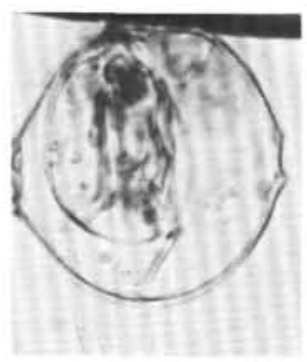

2

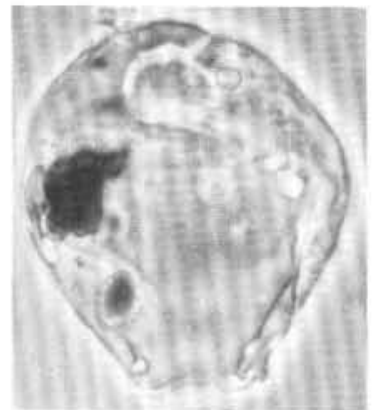

7

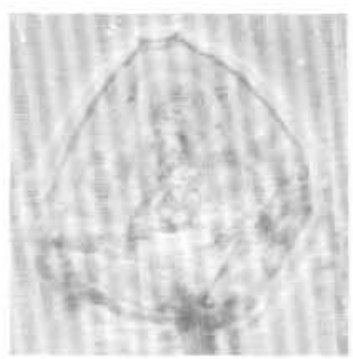

3

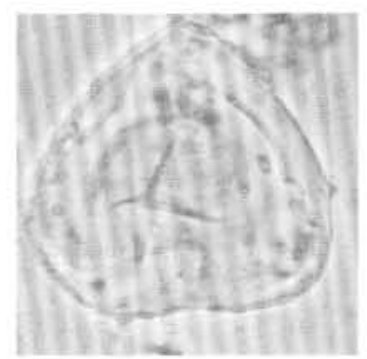

4

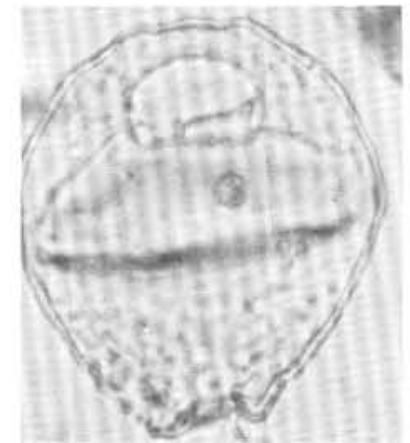

8

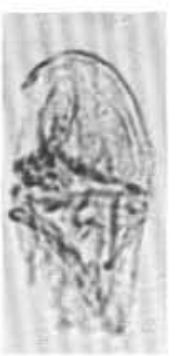

5

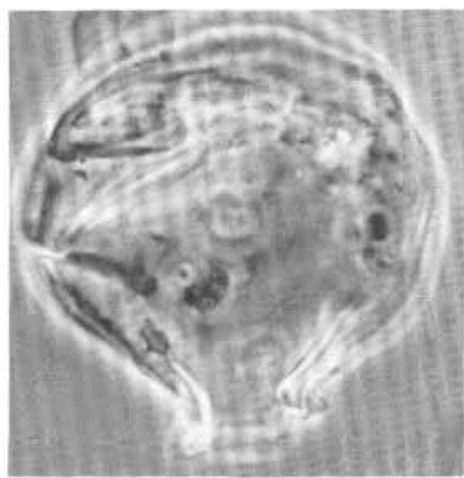

9

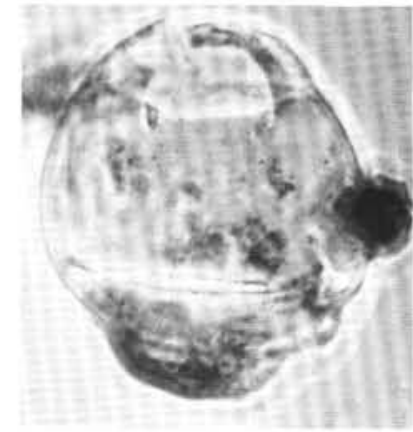

11

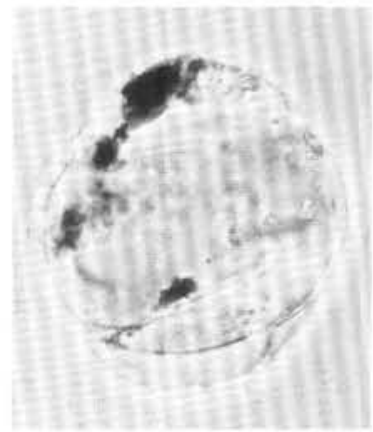

12

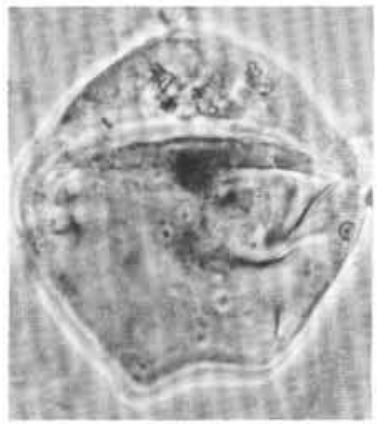

13

Plate 1. 1, 2, 6. Abratopdinium kerguelense n. sp. (1) Holotype, Sample 120-748C-36R-1, 68-70 cm, USNM no. $453931,47.6 \times 44 \mu \mathrm{m}$; (2) Sample 120-748C-40R-1, 20-23 cm, $\times 730$; (6) Sample 120-748C-40R-1, 67-69 cm, $\times 700$. 3, 4. Abratopdinium cardioforme $\mathrm{n}$. sp., Sample 120-748C-40R-1, 20-23 cm. (3) $\times 630$; (4) holotype, USNM no. 453932, $45.8 \times 53.1 \mu \mathrm{m}$. 5. Dinogymnium digitus, Sample 120-748C-48R-1, $80-85 \mathrm{~cm}, \times 600$. 7, 9. Isabelidinium cretaceum oviforme $\mathrm{n}$. subsp., Sample 120-748C-47R-CC. (7) Holotype, USNM no. $453935,90.5 \times 80.2$ $\mu \mathrm{m}$; (9) $\times 450$. 8. Isabelidinium cretaceum oviforme $\mathrm{n}$. subsp., Sample $120-748 \mathrm{C}-48 \mathrm{R}-1,80-85 \mathrm{~cm}, \times 450$. 10. Isabelidinium cretaceum cretaceum, $\times 450$, Sample 120-748C-48R-1, 80-86 cm. 11, 12. Isabelidinium cretaceum gravidum $\mathrm{n}$. subsp., Sample 120-748C-27R-2, 11-14 cm. (11) Holotype, USNM no. 453934, $84.2 \times 69.5 \mu \mathrm{m}$; (12) $\times 450$. 13. Nelsoniella sp., Sample 120-748C-47R-CC, $\times 450$. 


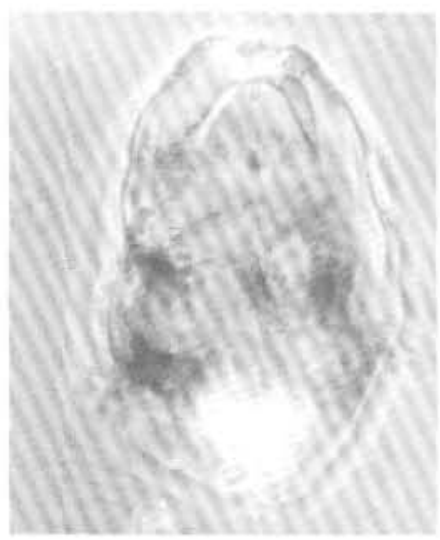

1

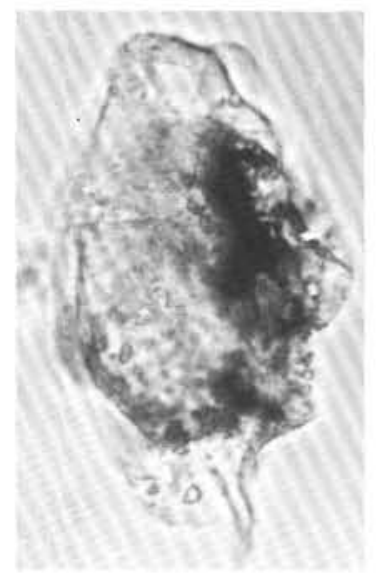

4

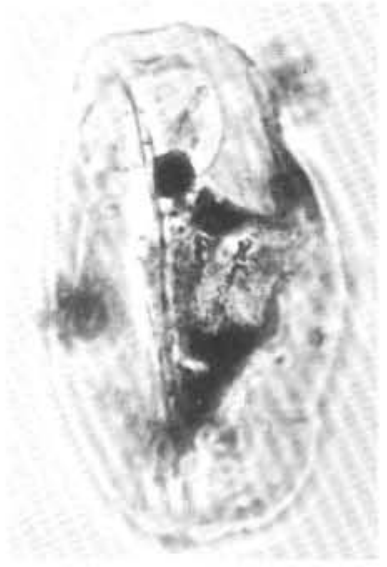

8
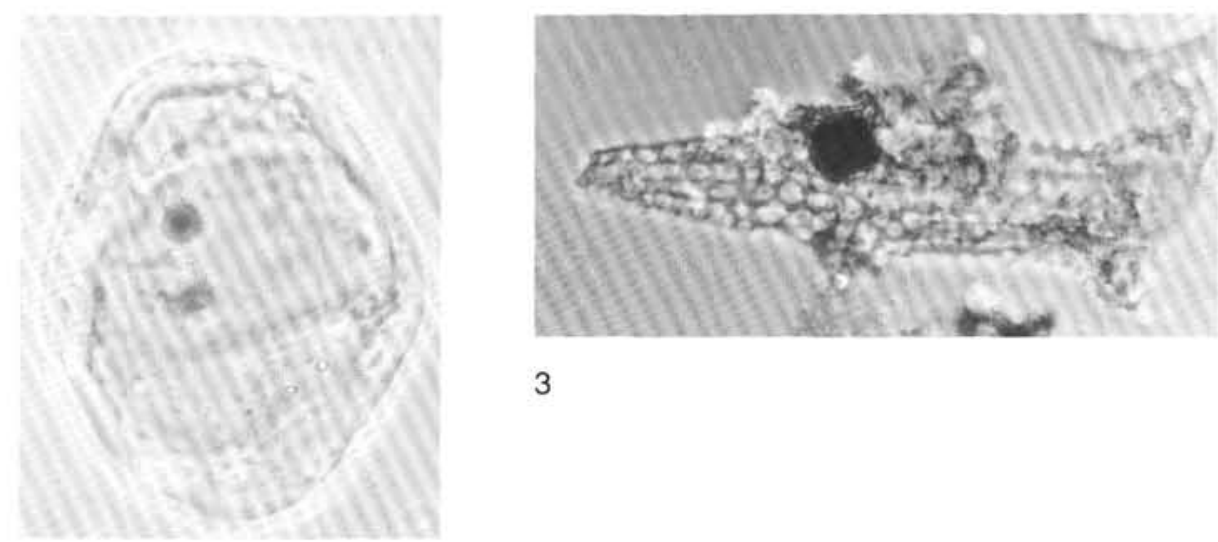

3

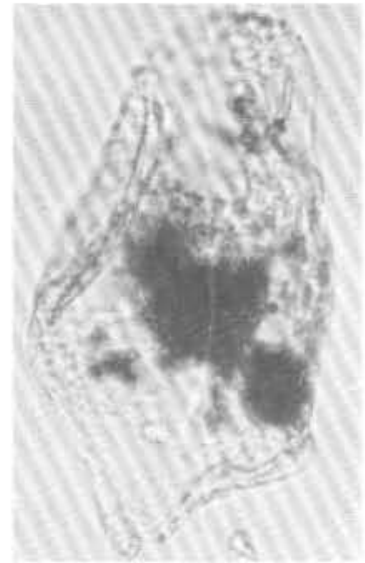

5

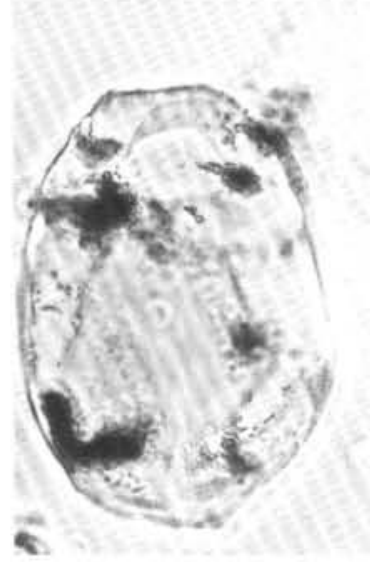

9

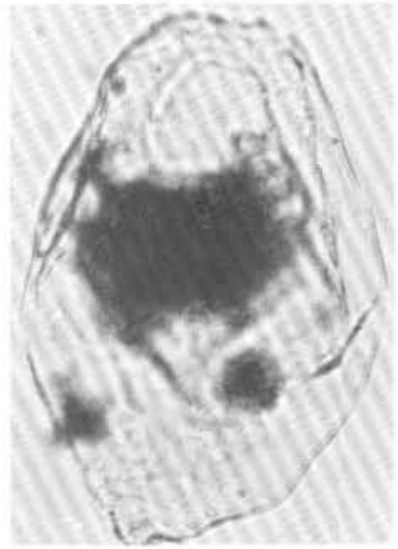

6

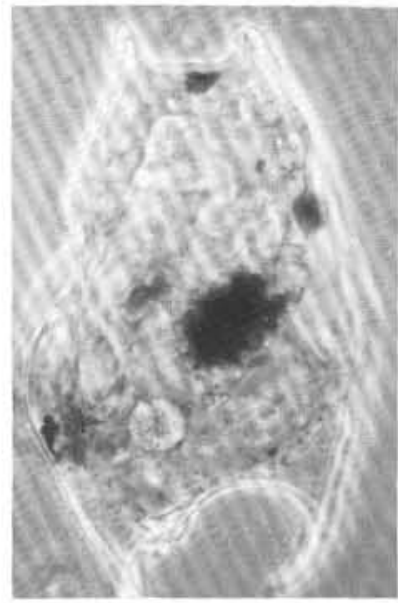

7

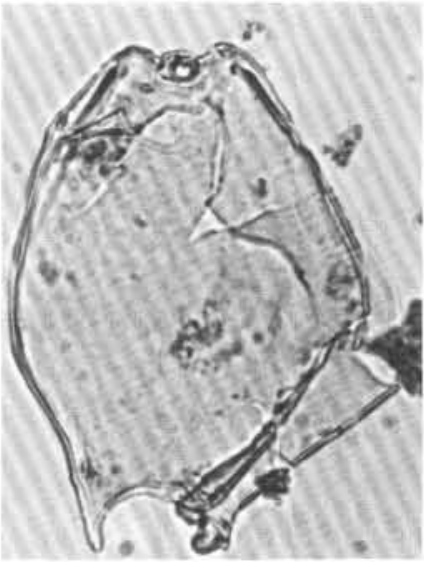

10

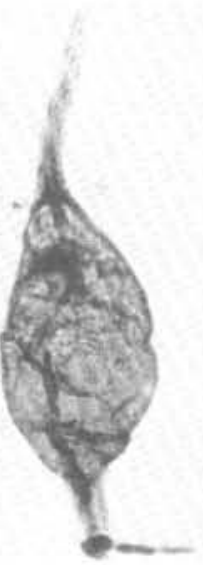

11

Plate 2. 1, 2, 8, 9. Eurydinium ellipticum n. sp. (1) Sample 120-748C-32R-1, 30-31 cm, $\times 500$; (2) Sample 120-748C-27R-2, 11-14 cm; (8) Sample 120-748C-32R-1, 30-31 cm, $\times 550$; (9) holotype, Sample 120-748C-32R-1, 30-31 cm, USNM no. 453933, 100.5 $\times 71.4 \mu \mathrm{m} .3$. Odontochitina porifera, Sample 120-748C-34R-1, 62-65 cm, $\times 400$. 4-6. Satyrodinium haumuriense, Sample 120-748C-32R-1, 30-31 cm, $\times 550.7,10$. Satyrodinium bengalense. (7) Sample 120-748C-32R-1, 30-31 cm, $\times 550$; (10) Sample 120-748C-36R-1, 93-95 cm, $\times 400$. 11. Palaeocystodinium sp. cf. $P$. scabratum, Sample 120-748C-27R-2, $11-14 \mathrm{~cm}, \times 250$. 


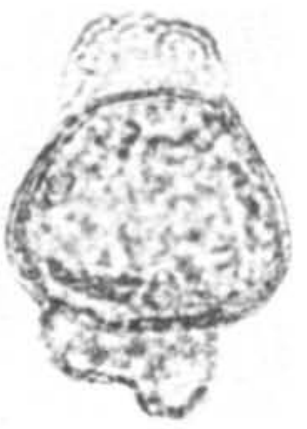

1

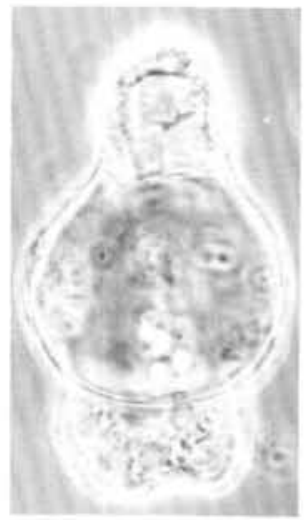

6

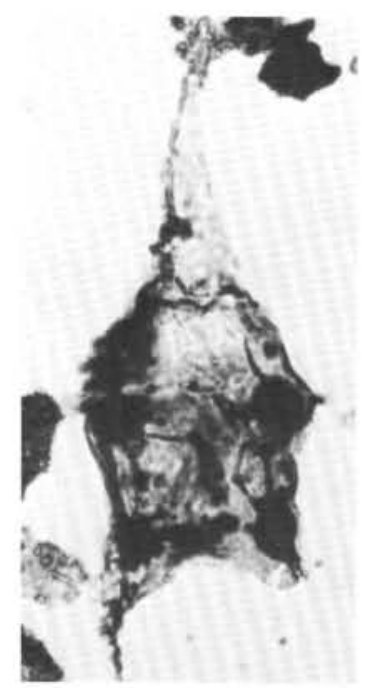

10

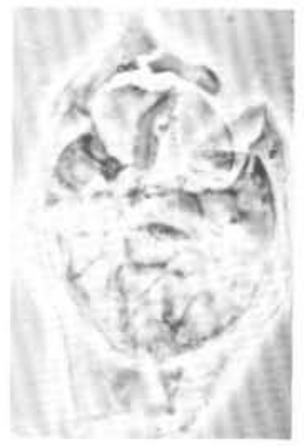

2

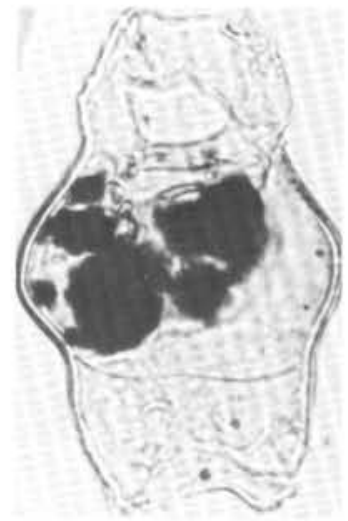

7

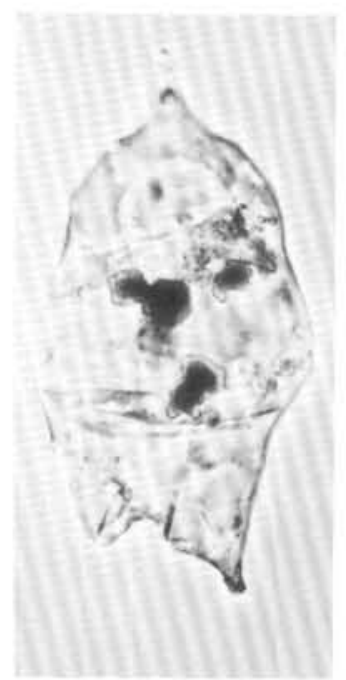

11

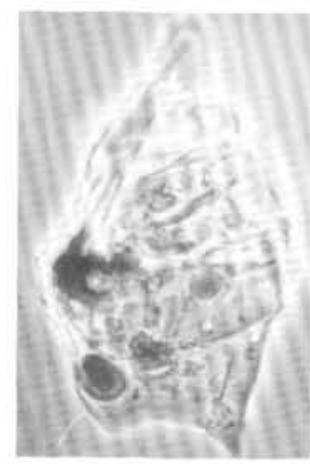

3

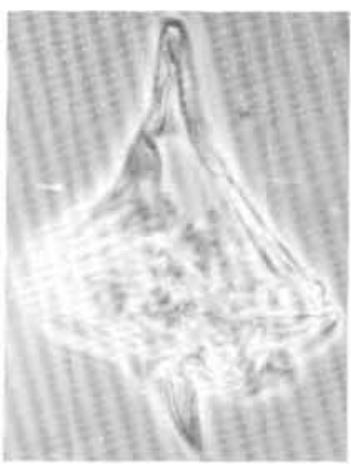

4

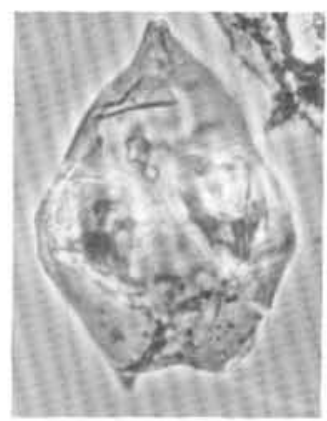

5

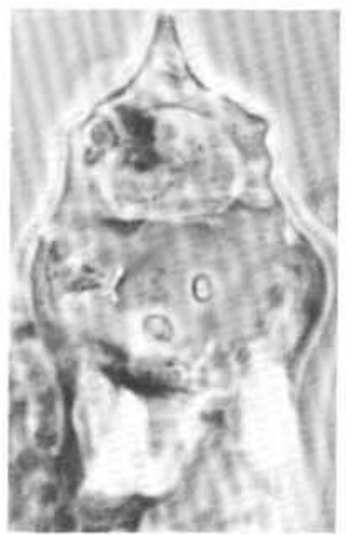

8
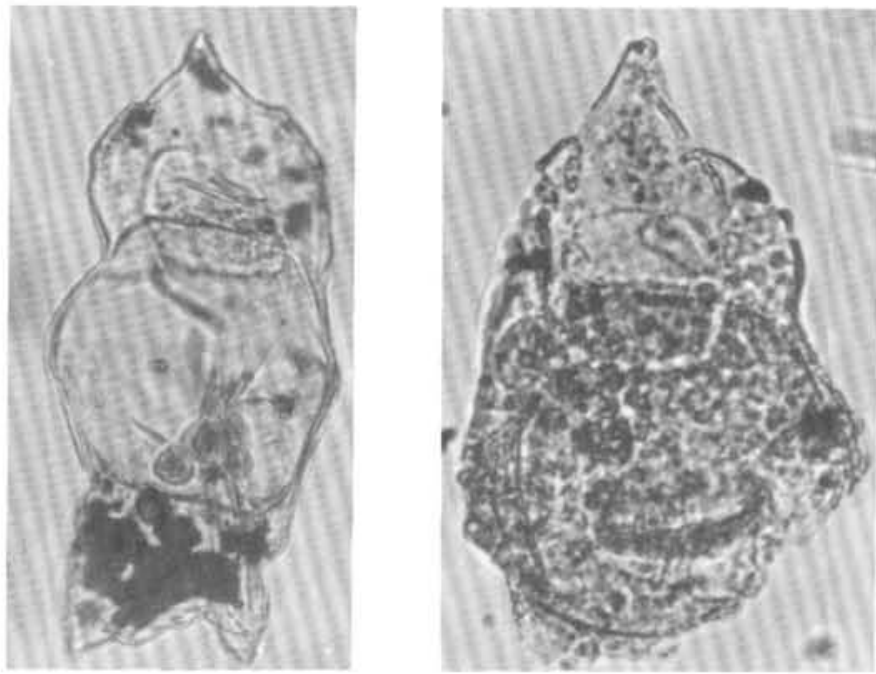

13

Plate 3. 1. Amphidiadema sp., Sample 120-748C-48R-1, $80-85 \mathrm{~cm}, \times 550$. 2. Chatangiella spectabilis, Sample $120-748 \mathrm{C}-55 \mathrm{R}-2,125-129 \mathrm{~cm}$, $\times 550$. 3. Isabelidinium cooksoniae, Sample $120-748 \mathrm{C}-34 \mathrm{R}-1,62-65 \mathrm{~cm}, \times 600$. 4. Diconodinium sp., Sample 120-748C-35R-1, 93-95 cm, $\times 600$. 5. Isabelidinium acuminatum, Sample 120-748C-50R-1, 50-52 cm, $\times 500$. 6, 7. Amphidiadema denticulata, $\times 500$. (6) Sample 120-748C-48R-1, 80-85 cm; (7) Sample 120-748C-50R-1, 50-52 cm. 8. Eurydinium ingramii, Sample 120-748C-50R-1, 50-52 cm, $\times 450.9$. Chatangiella ditissima, Sample 120-748C-55R-2, 125-129 cm, $\times 550$. 10. Cerodinium diebelii, Sample $120-748 \mathrm{C}-32 \mathrm{R}-1,30-31 \mathrm{~cm}, \times 450.11$. Isabelidinium microarmum, Sample 120-748C-51R-1, $105-108 \mathrm{~cm}, \times 450$. 12. Chatangiella tripartita, Sample $120-748 \mathrm{C}-62 \mathrm{R}-1,52-55 \mathrm{~cm}, \times 550$. 13 . Chatangiella verrucosa, Sample 120-748C-50R-1, $50-52 \mathrm{~cm}, \times 500$. 


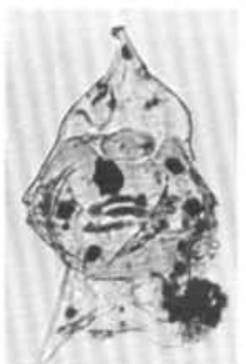

1

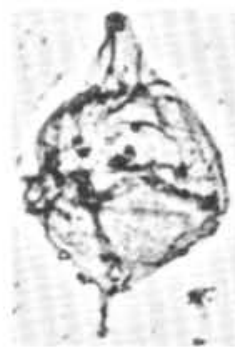

2

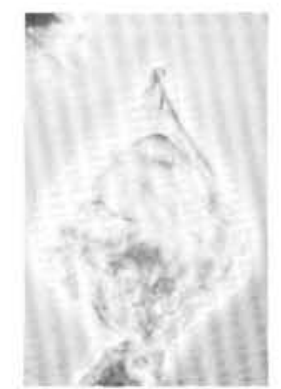

3

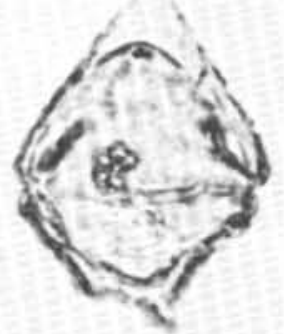

4

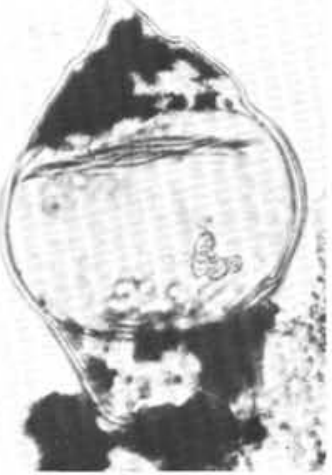

8

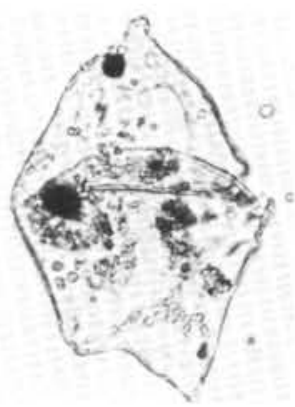

5

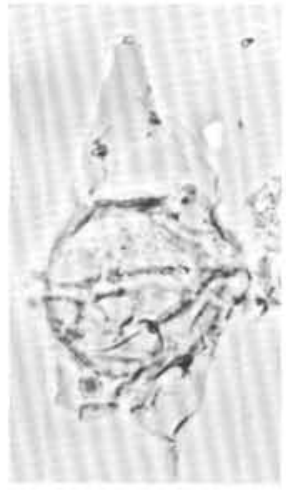

6

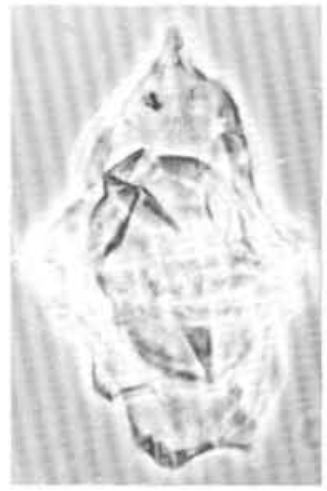

7

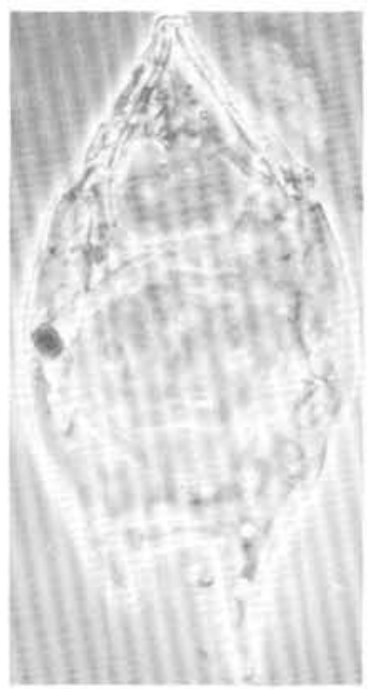

11

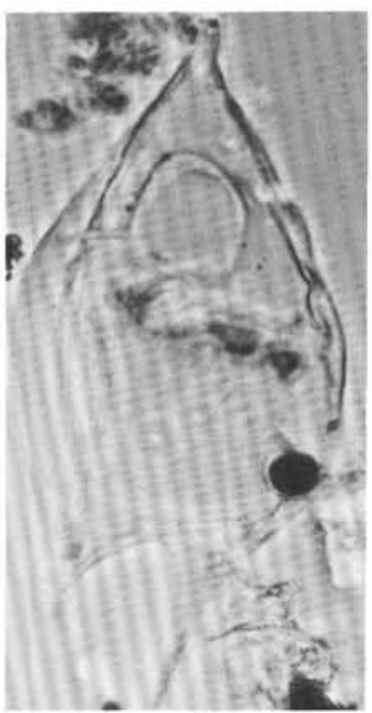

12

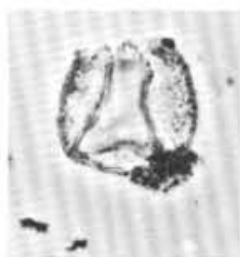

13

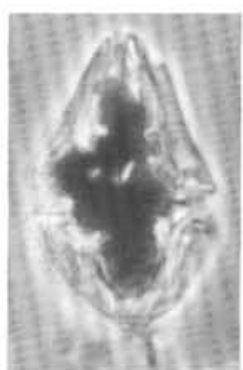

14

Plate 4. 1. Chatangiella victoriensis, Sample $120-748 \mathrm{C}-50 \mathrm{R}-1,50-52 \mathrm{~cm}, \times 300.2$. Laciniadinium firmum, Sample 120-748C-56R-1, $77-79 \mathrm{~cm}$, $\times 600$. 3. Diconodinium sp. cf. D. arcticum, Sample $120-748 \mathrm{C}-34 \mathrm{R}-1,62-65 \mathrm{~cm}, \times 550$. 4. Alterbidinium acutulum, Sample $120-748 \mathrm{C}-29 \mathrm{R}-1$, $30-31 \mathrm{~cm}, \times 500$. 5. Isabelidinium belfastense, Sample 120-748C-28R-1, 48-51 cm, $\times 500.6$. Chatangiella serratula, Sample 120-748C-32R-1, $30-31 \mathrm{~cm}, \times 500$. 7. Chatangiella tripartita, Sample $120-748 \mathrm{C}-55 \mathrm{R}-1,42-45 \mathrm{~cm}, \times 450.8$, 9. Isabelidinium pellucidum, $\times 450$. (8) Sample 120-748C-29R-1, 30-31 cm; (9) Sample 120-748C-32R-1, 30-31 cm. 10. Manumiella sp. cf. M. sp. 2 of Askin (1988, pp. 144-145, fig. 9-4), Sample 120-748C-34R-1, 62-65 cm, $\times 500$. 11, 12. Isabelidinium sp. A, Sample 120-748C-34R-1, $62-65 \mathrm{~cm}, \times 500$. 13. Kallosphaeridium? helbyi, Sample 120-748C-32R-1, 30-31 cm, $\times 500$. 14. Dinogymnium albertii, Sample $120-748 \mathrm{C}-50 \mathrm{R}-1,50-52 \mathrm{~cm}, \times 500$. 


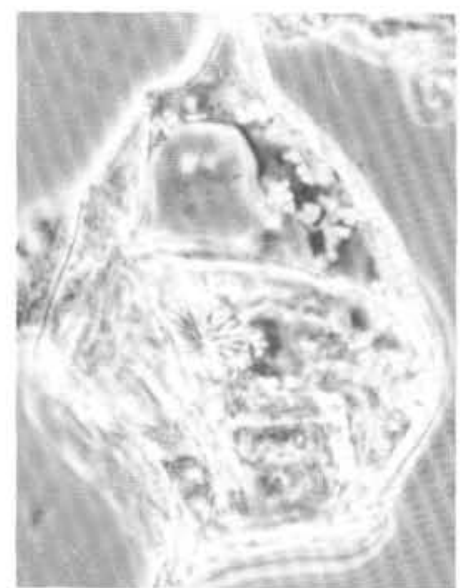

1

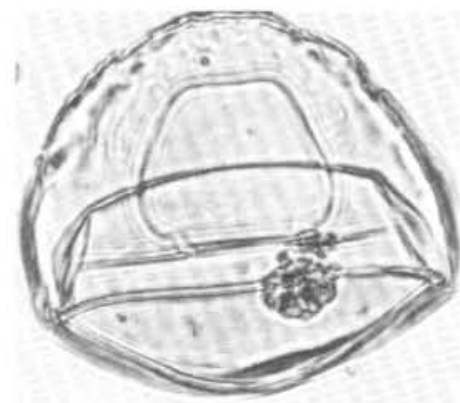

6

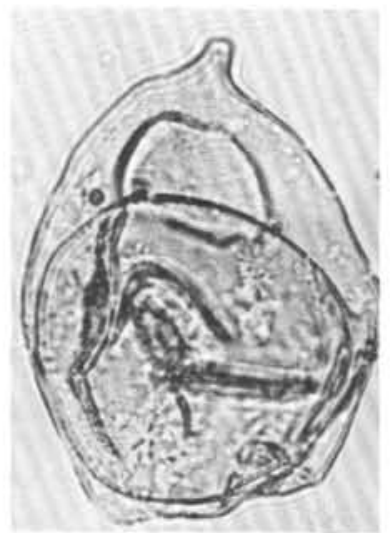

10

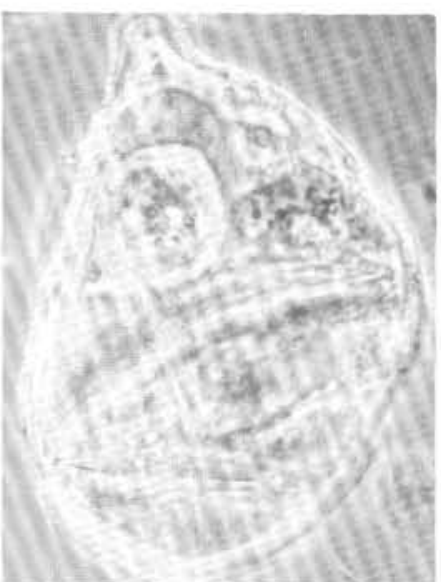

2

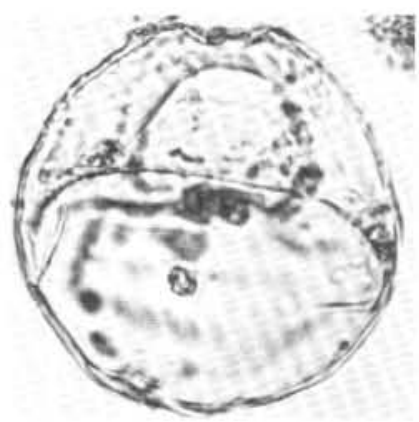

7

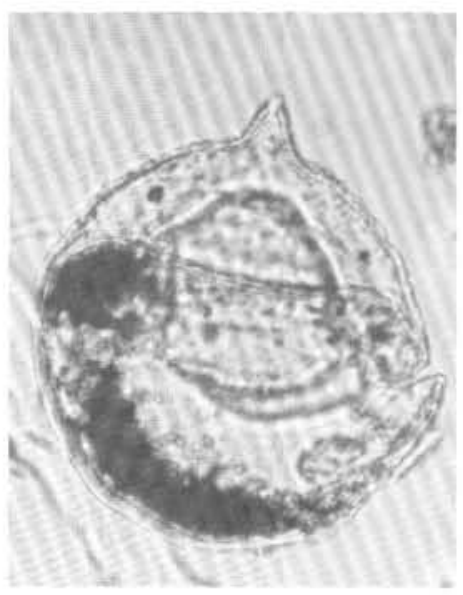

3

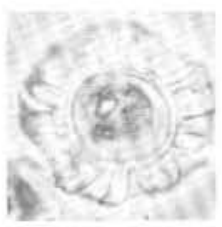

4

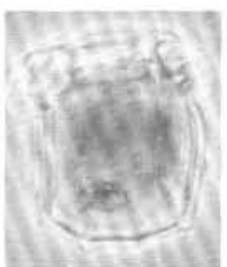

5
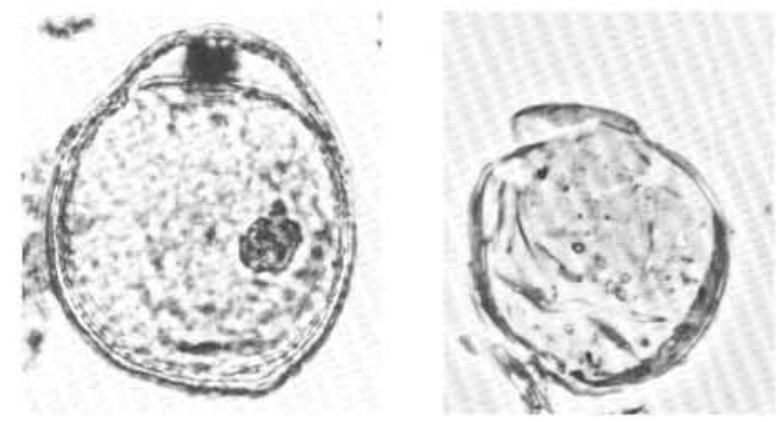

8

9

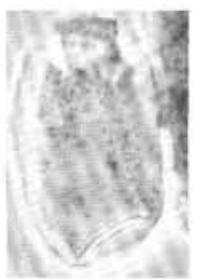

12

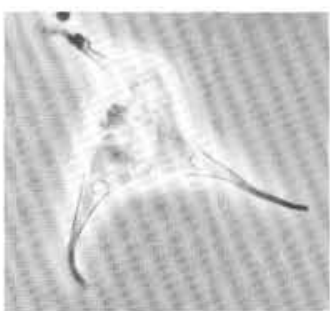

15

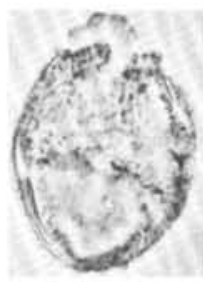

13

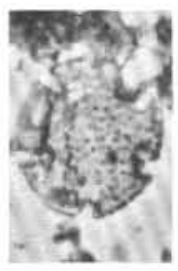

14

Plate 5. 1. Eucladinium gambangense, Sample $120-748 \mathrm{C}-43 \mathrm{R}-1,60-63 \mathrm{~cm}, \times 600.2$, 3. Nelsoniella tuberculata, $\times 450$. (2) Sample 120-748C-41R-1, 20-23 cm; (3) Sample 120-748C-40R-1, 67-69 cm. 4. Pterospermella australiensis, Sample 120-748C-45R-1, 112-115 cm, $\times 700$. 5. Gillinia hymenophora, Sample 120-748C-34R-1, 62-65 cm, $\times 700.6,7$. Nelsoniella aceras, Sample 120-748C-44R-1, 126-128 cm, $\times 500$. 8. Xenikoon australis, Sample $120-748 \mathrm{C}-35 \mathrm{R}-1,93-95 \mathrm{~cm}, \times 550.9$. Eschariasphaeridia $\mathrm{sp}$., Sample $120-748 \mathrm{C}-55 \mathrm{R}-1,42-45 \mathrm{~cm}, \times 450$. 10. Eucladinium madurense, Sample $120-748 \mathrm{C}-43 \mathrm{R}-1,60-63 \mathrm{~cm}, \times 600$. 11. Palambages morulosa, Sample $120-748 \mathrm{C}-35 \mathrm{R}-1,93-95 \mathrm{~cm}, \times 500$. 12, 13. Elytrocysta druggii, $\times 500$. (12) Sample 120-748C-36R-1, 68-70 cm; (13) Sample 120-748C-35R-1, 93-95 cm. 14. Nothofagidites sp., Sample $120-748 \mathrm{C}-36 \mathrm{R}-1,68-70 \mathrm{~cm}, \times 500$. 15. Veryhachium $\mathrm{sp}$., Sample $120-748 \mathrm{C}-52 \mathrm{R}-1,45-47 \mathrm{~cm}, \times 500$. 16. Proteacidites sp., Sample $120-748 \mathrm{C}-44 \mathrm{R}-1,67-69 \mathrm{~cm}, \times 500$. 

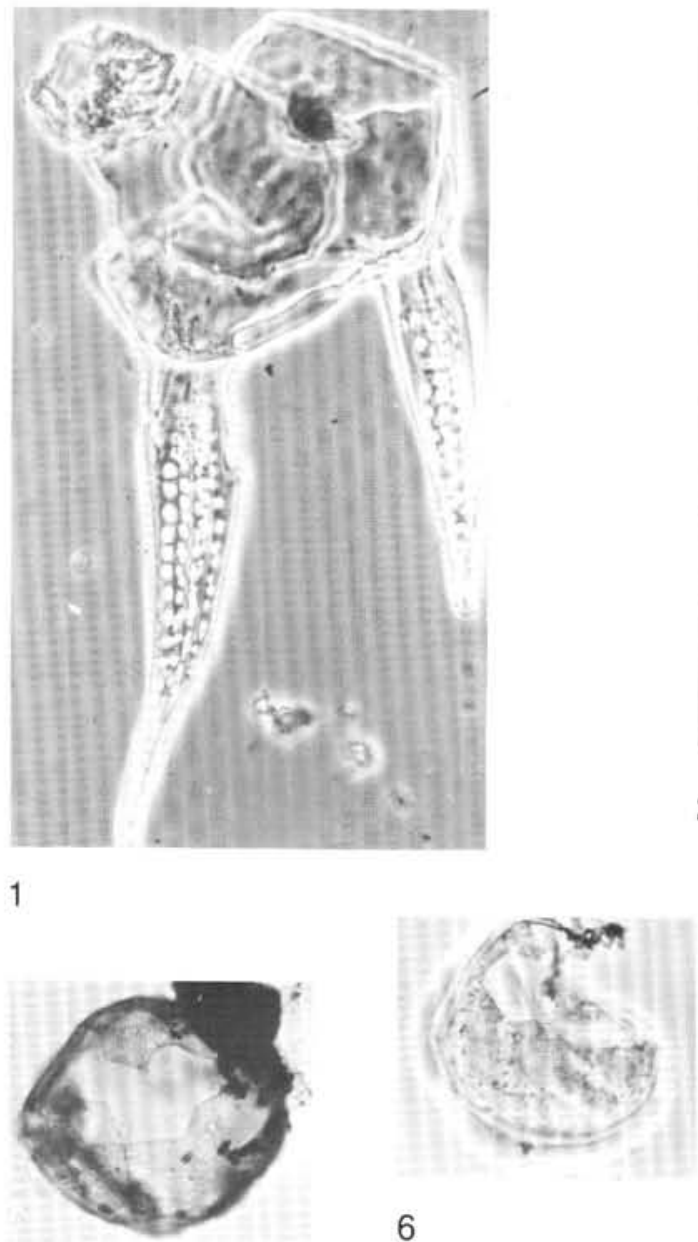

6

5

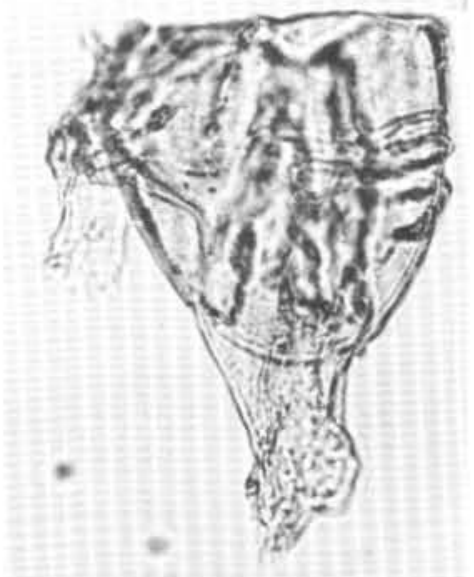

10

Plate 6. 1. Odontochitina porifera, Sample 120-748C-43R-1, 60-63 cm, $\times 350$. 2. Odontochitina cribropoda, Sample 120-748C-48R-1, 80-85 cm, $\times 400$. 3. Spinidinium uncinatum, Sample $120-748 \mathrm{C}-52 \mathrm{R}-1,45-47 \mathrm{~cm}, \times 500.4$. Chlamydophorella discreta, Sample-120-748C-56R-1, 77-79 $\mathrm{cm}$, $\times 600$. 5. Trithyrodinium fragile, Sample $120-748 \mathrm{C}-34 \mathrm{R}-1,62-65 \mathrm{~cm}, \times 500.6$. Trithyrodinium suspectum, Sample $120-748 \mathrm{C}-32 \mathrm{R}-1,30-31 \mathrm{~cm}$, $\times 500.7$. Tanyosphaeridium xanthiopyxides, Sample $120-748 \mathrm{C}-36 \mathrm{R}-1,68-70 \mathrm{~cm}, \times 500$. 8. Fromea chytra, Sample $120-748 \mathrm{C}-36 \mathrm{R}-1,68-70 \mathrm{~cm}$, $\times 600$. 9. Alnipollenites sp., Sample $120-748 \mathrm{C}-32 \mathrm{R}-1,30-31 \mathrm{~cm}, \times 1000.10,12$. Xenascus ceratioides, $\times 500$. (10) Sample $120-748 \mathrm{C}-55 \mathrm{R}-1$, $42-45 \mathrm{~cm}$; (12) Sample 120-748C-33R-1, 37-40 cm. 11. Odontochitina operculata, Sample 120-748C-51R-1, $105-108 \mathrm{~cm}, \times 400$. 


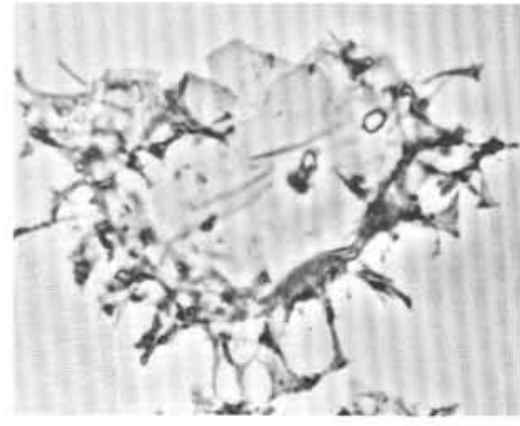

1

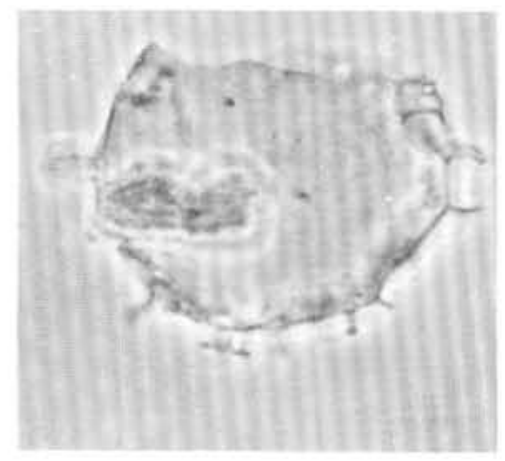

5

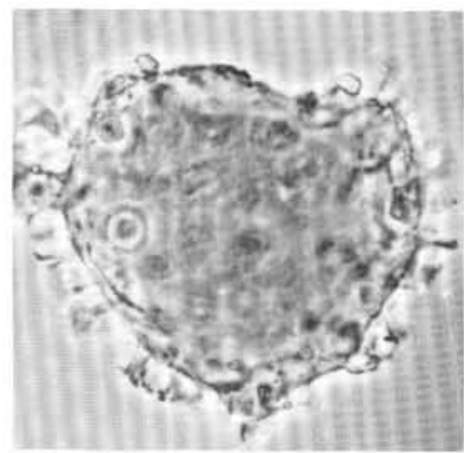

6

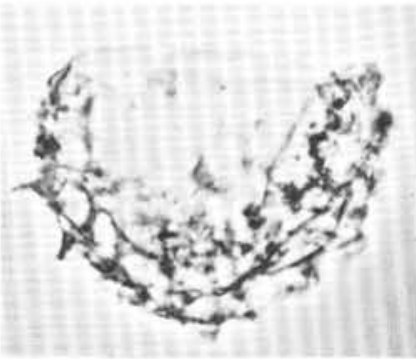

2

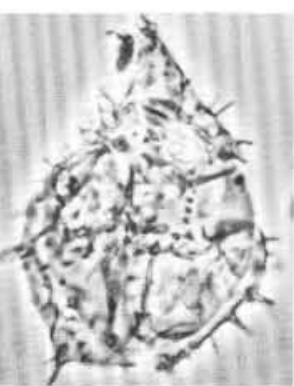

3

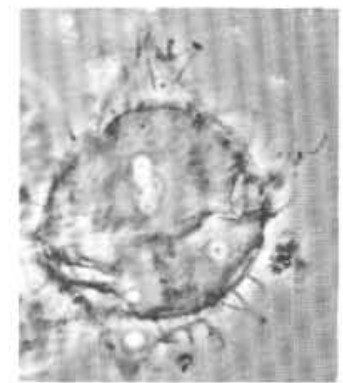

4

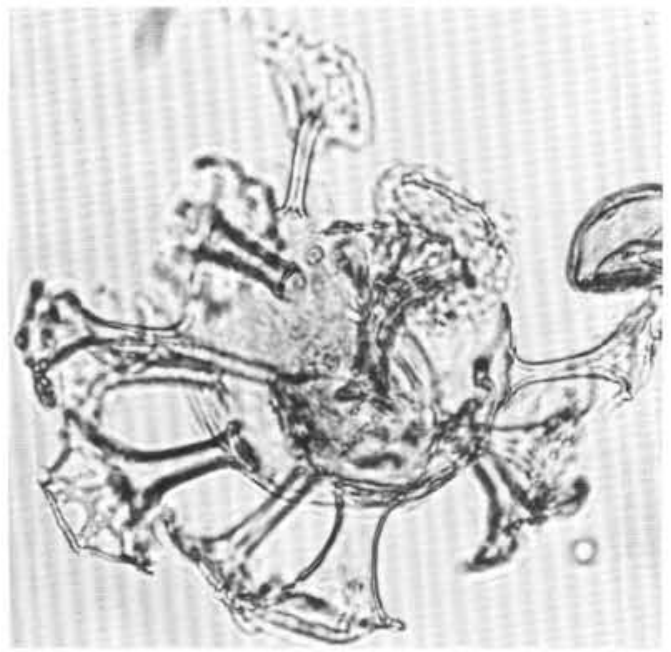

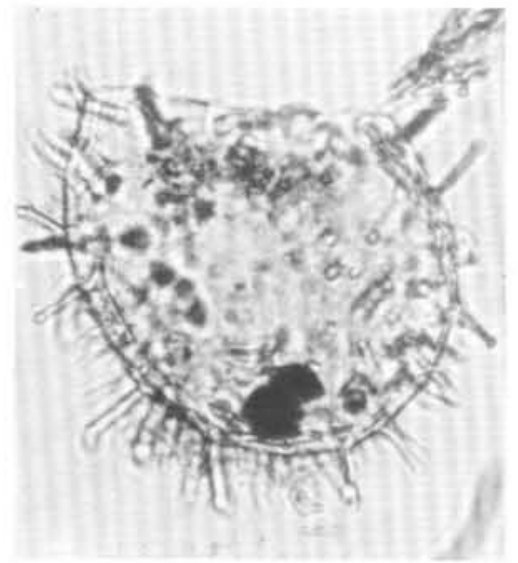

8

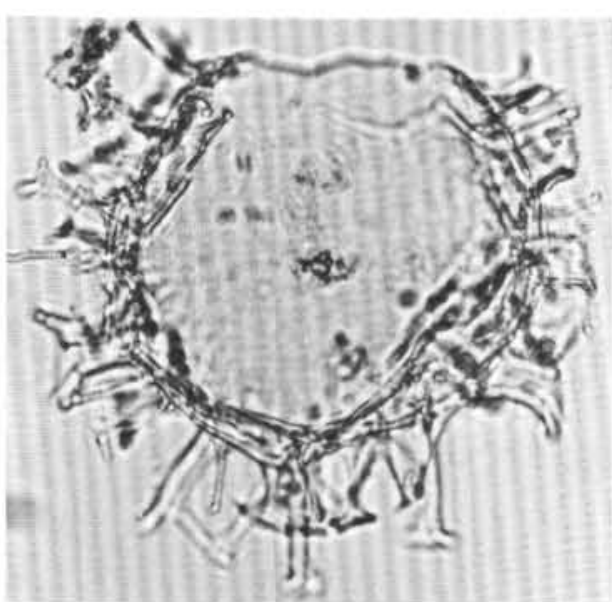

9

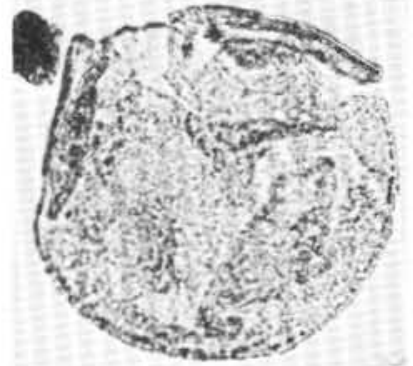

10

Plate 7. 1, 8. Circulodinium distinctum subsp. longispinatum, $\times 500$. (1) Sample 120-748C-52R-1, 45-47 cm; (8) Sample 120-748C-50R-1, 50-52 cm. 2, 6. Cyclonephelium compactum, $\times 500$. (2) Sample 120-748C-51R-1, 105-108 cm; (6) Sample 120-748C-56R-1, 77-79 cm. 3. Spinidinium lanternum, Sample 120-748C-52R-1, 45-47 cm, $\times 600$. 4. Palaeohystrichophora infusorioides, Sample 120-748C-44R-1, 67-68 $\mathrm{cm}, \times 500$. 5. Circulodinium distinctum subsp. distinctum, Sample $120-748 \mathrm{C}-56 \mathrm{R}-1,77-79 \mathrm{~cm}, \times 500$. 7. Oligosphaeridium pulcherrimum, Sample 120-748C-55R-2, 125-129 cm, $\times 500$. 9. Cyclonephelium crassimarginatum, Sample $120-748 \mathrm{C}-52 \mathrm{R}-1,45-47 \mathrm{~cm}, \times 500.10$. Canningia reticulata, Sample $120-748 \mathrm{C}-52 \mathrm{R}-1,45-47 \mathrm{~cm}, \times 500$. 


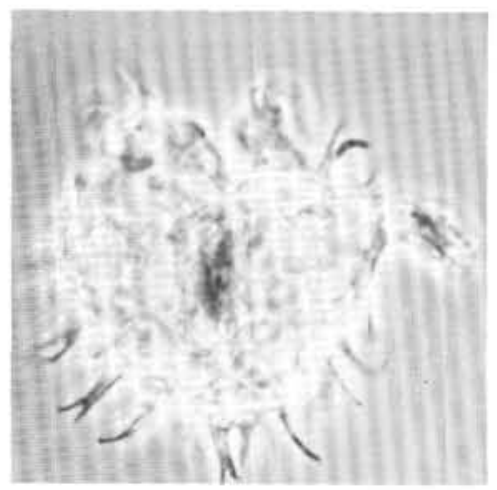

1

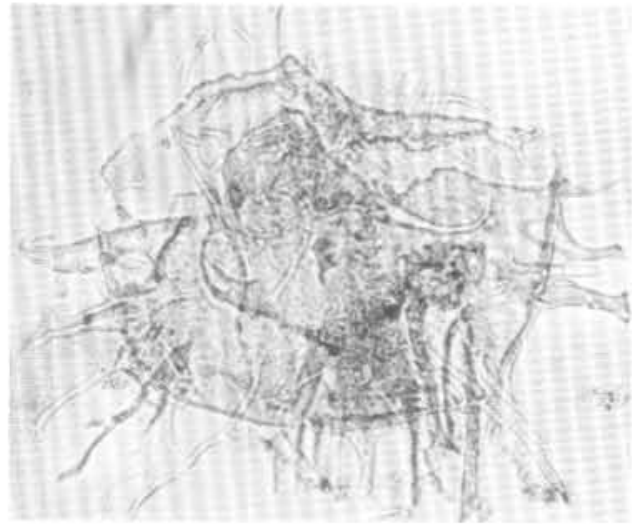

4

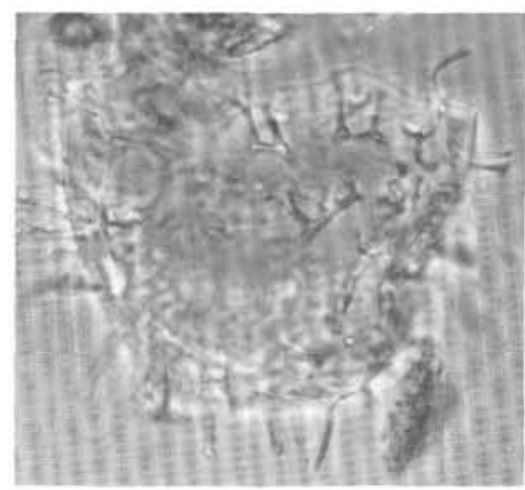

2

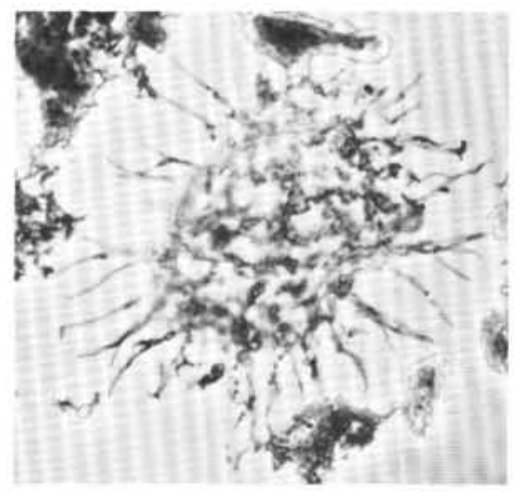

3

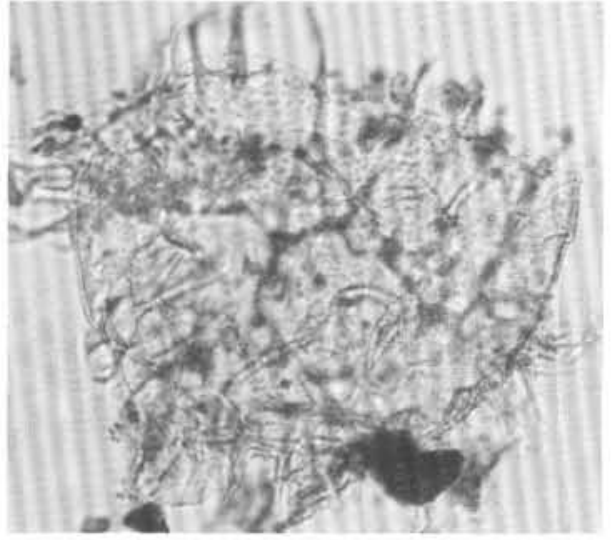

5

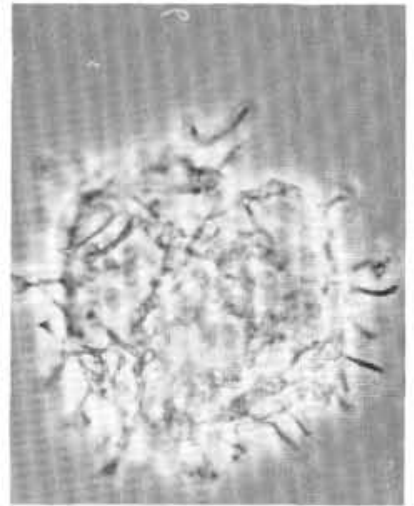

6

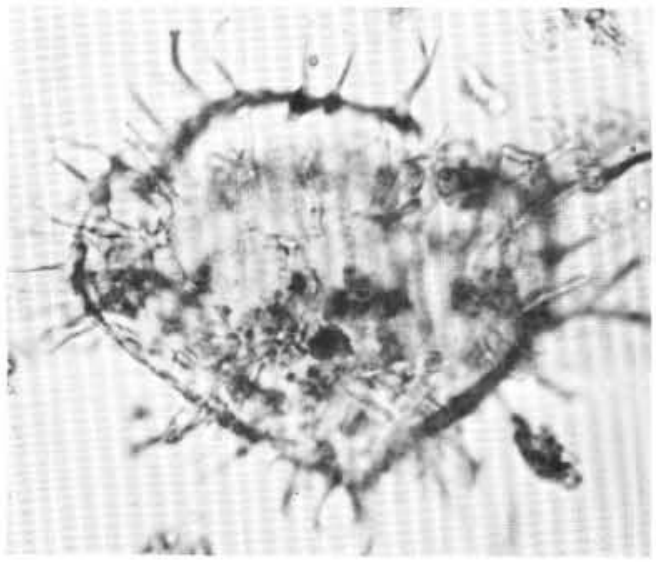

7

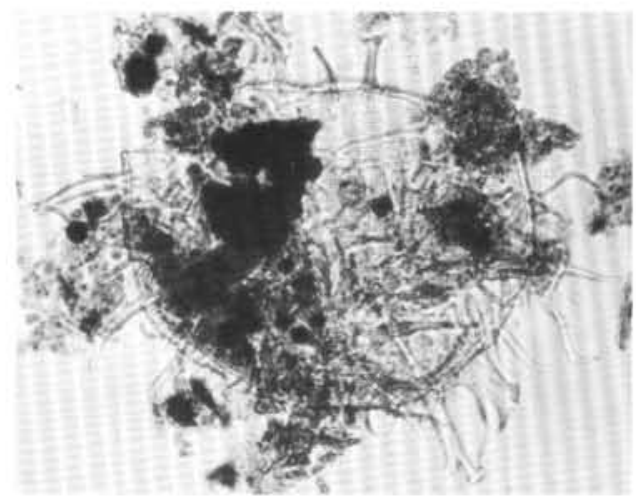

8

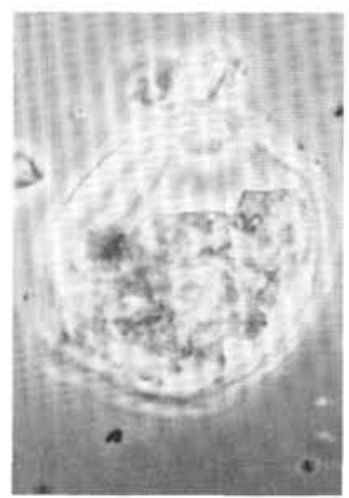

9

Plate 8. 1. Areoligera senonensis, Sample 120-748C-55R-2, 125-129 cm, $\times 450$. 2. Heterosphaeridium? heteracanthum, Sample 120-748C$41 \mathrm{R}-1,20-23 \mathrm{~cm}, \times 500$. 3. Hystrichodinium pulchrum, Sample $120-748 \mathrm{C}-52 \mathrm{R}-1,45-47 \mathrm{~cm}, \times 500.4,5$, 8. Heterosphaeridium conjunctum, $\times 500$. (4) Sample 120-748C-41R-1, 20-23 cm; (5), (8) Sample 120-748C-35R-1, 93-95 cm. 6. Heterosphaeridium sp., Sample 120-748C-43R-1, $60-63 \mathrm{~cm}, \times 500$. 7. Areoligera $\mathrm{sp}$. cf. A. senonensis, Sample 120-748C-48R-1, 80-85 cm, $\times 500$. 9. Trithyrodinium suspectum, Sample $120-748 \mathrm{C}-48 \mathrm{R}-1,80-85 \mathrm{~cm}, \times 500$. 


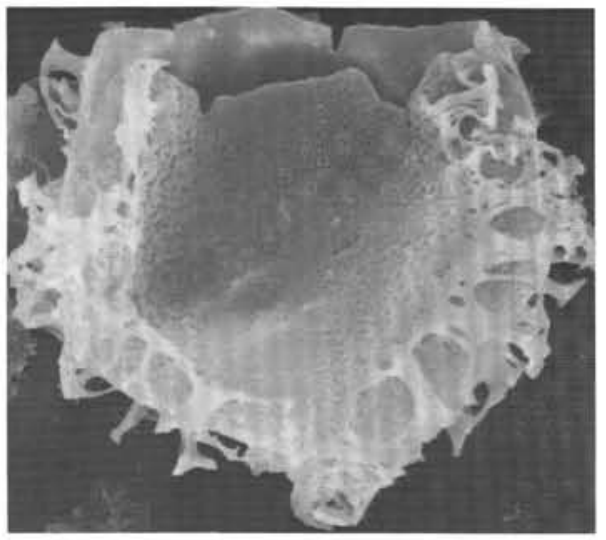

1

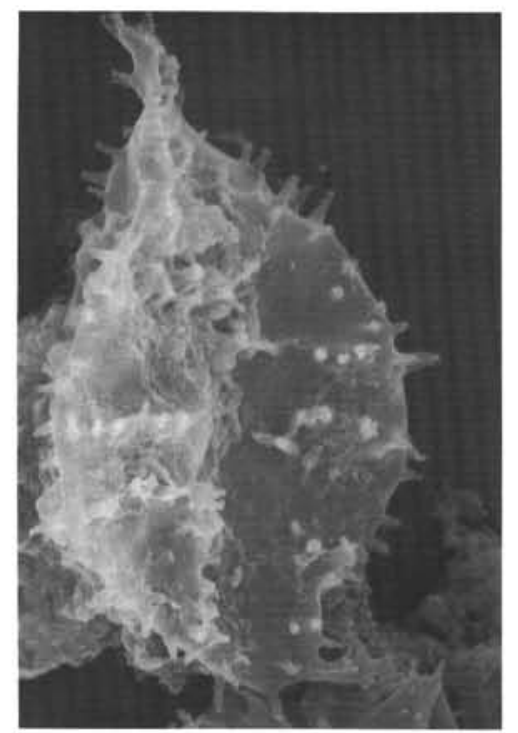

4

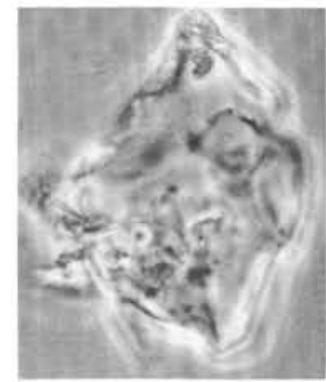

7

5

8

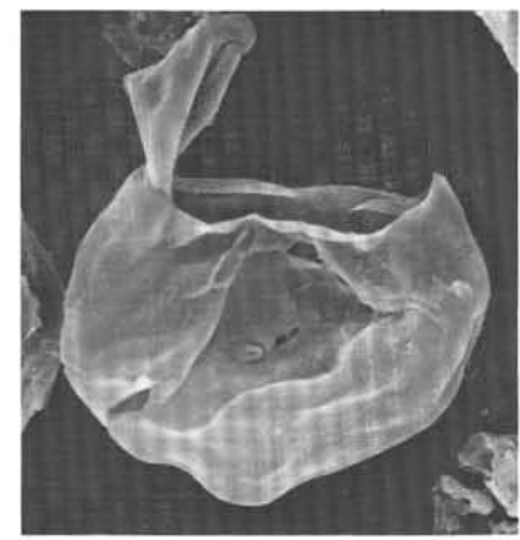

2
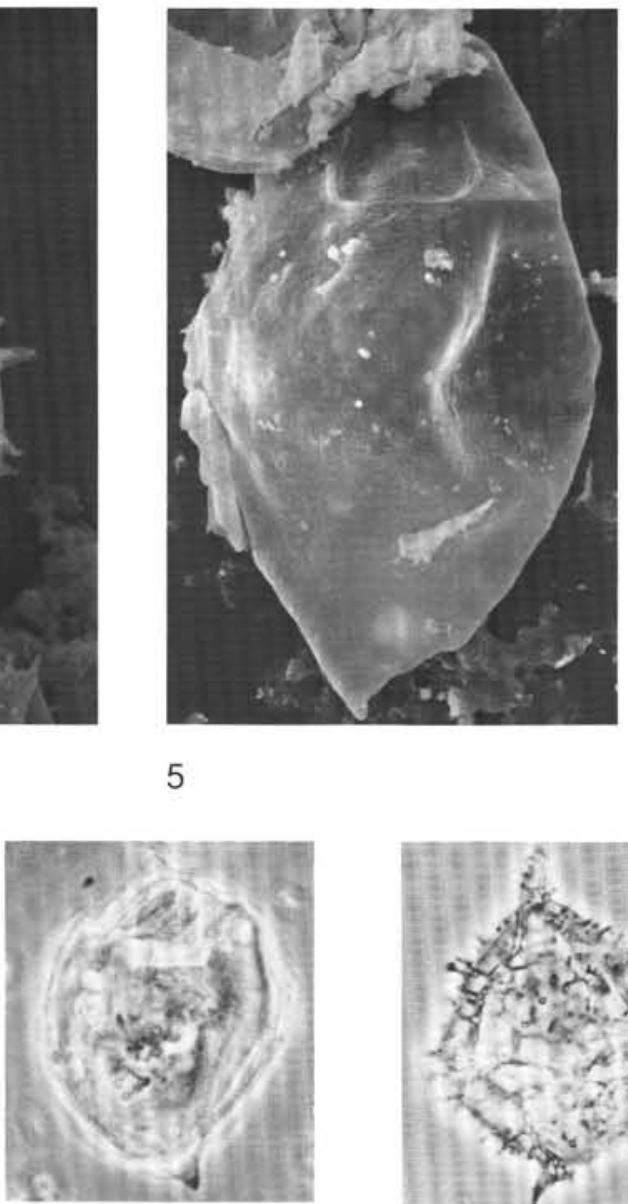

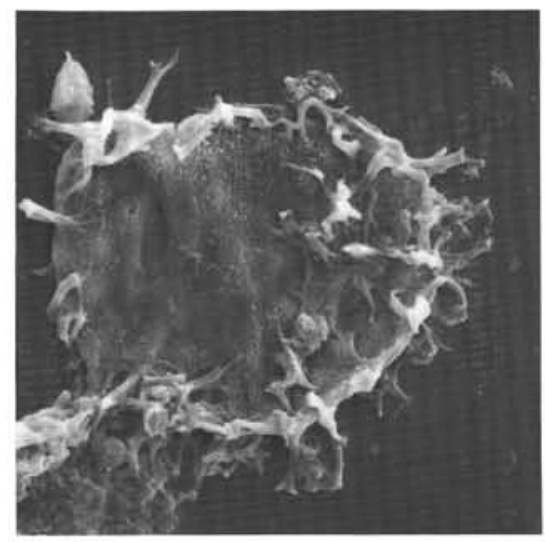

3

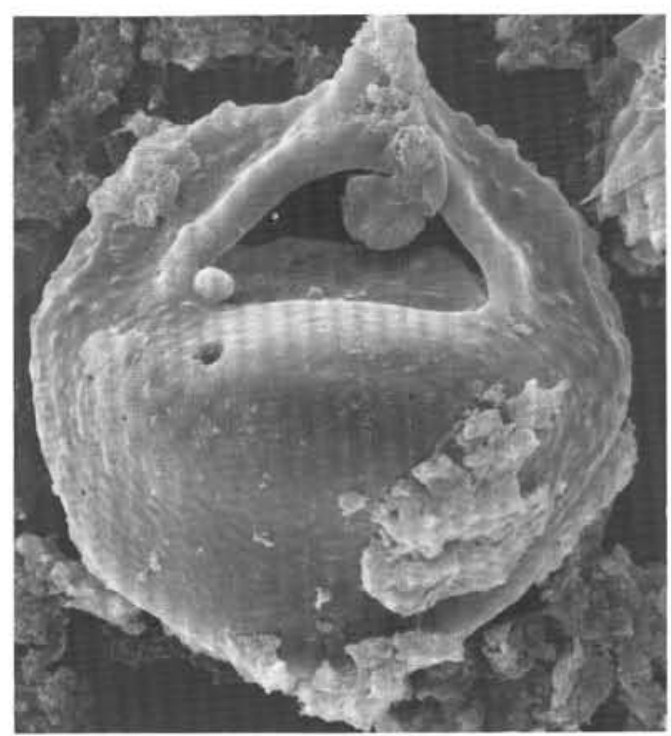

6

Plate 9. 1-6 SEM photographs. 1. Cyclonephelium crassimarginatum, Sample 120-748C-55R-2, 125-129 cm, $\times 900$. 2. Canningia sp., Sample 120-748C-56R-1, 77-79 cm, $\times 900$. 3. Circulodinium distinctum subsp. distinctum, Sample 120-748C-50R-1, 50-52 cm, $\times 900.4$. Spinidinium? clavus, Sample 120-748C-52R-1, 45-47 cm, $\times 1700$. 5. Satyrodinium haumuriense, Sample 120-748C-32R-1, 30-31 cm, $\times 700.6$. Nelsoniella tuberculata, Sample 120-748C-48R-1, 80-85 cm, $\times 700$. 7. Pierceites schizocystis, Sample 120-748C-44R-1, 67-69 cm, $\times 500.8$. Trithyrodinium suspectum, Sample 120-748C-48R-1, 80-85 cm, $\times 500$. 9. Spinidinium lanternum, Sample $120-748 \mathrm{C}-52 \mathrm{R}-1,45-47 \mathrm{~cm}, \times 600$. 10. Elytrocysta druggii, Sample 120-748C-37R-1, 74-78 cm, $\times 500$. 11. Alterbidinium minus, Sample 120-748C-55R-2, 125-129 cm, $\times 500$. 


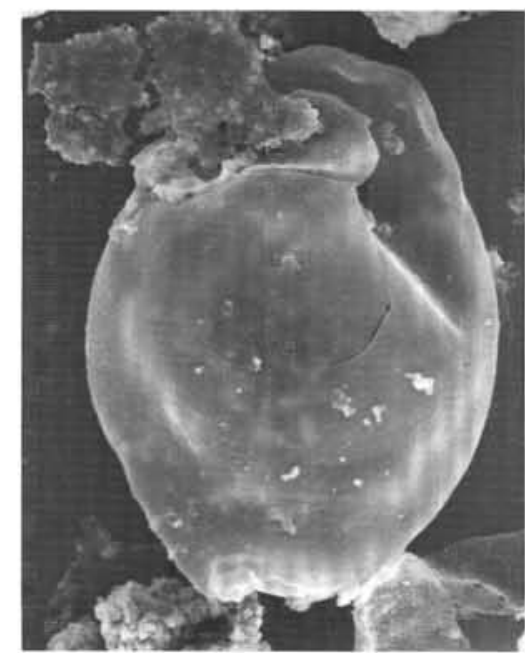

1

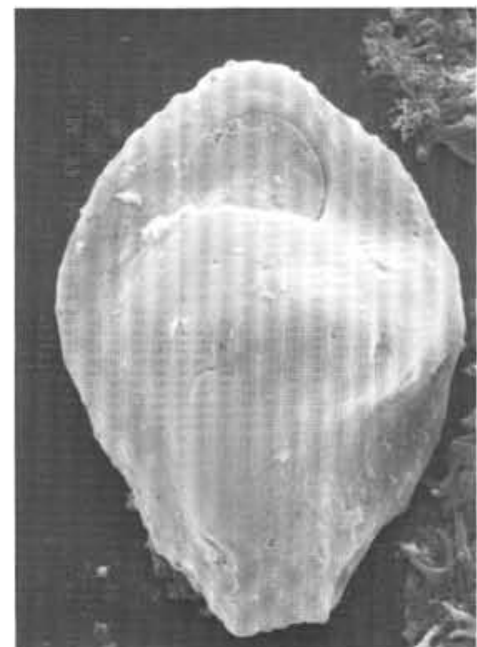

2

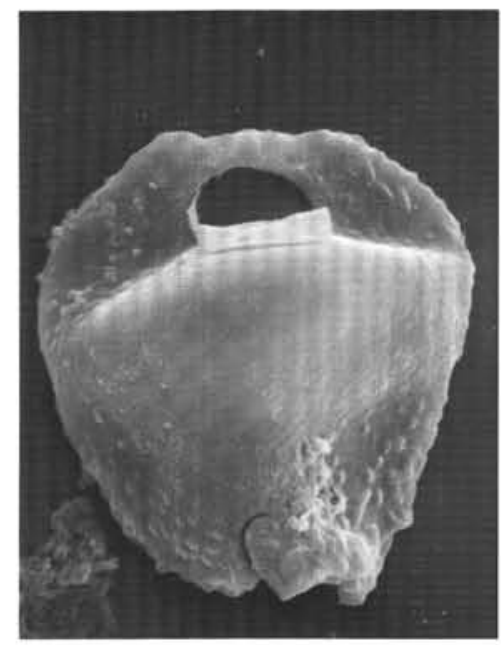

3

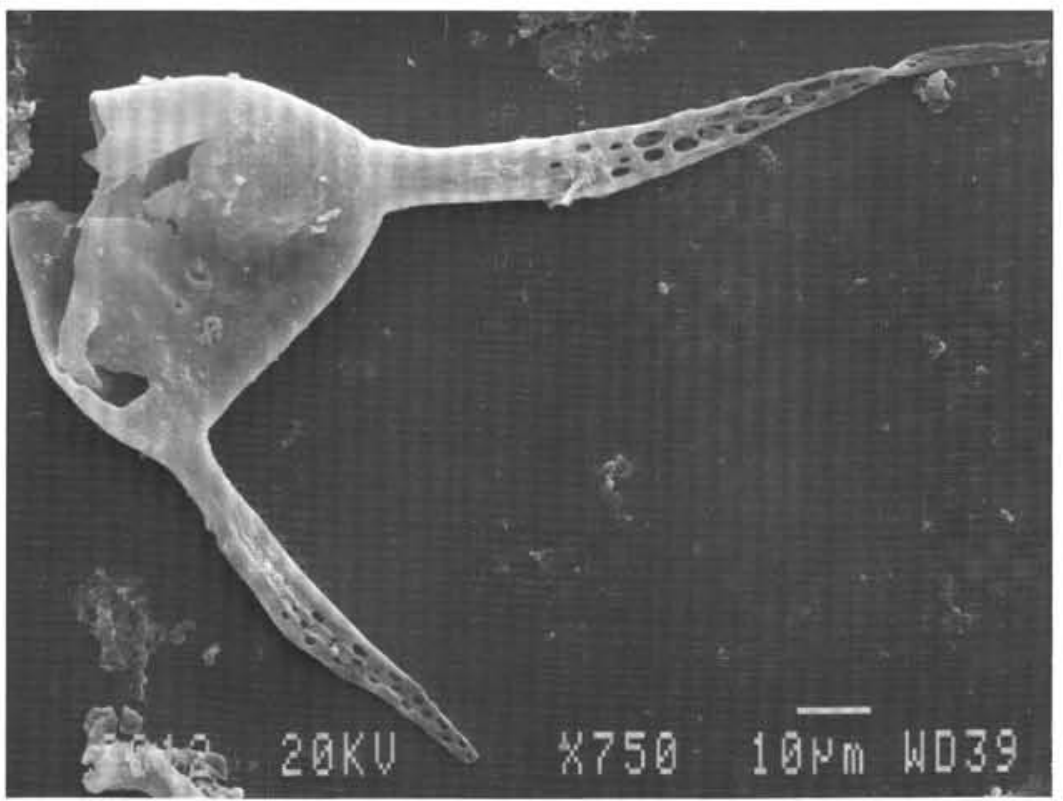

4

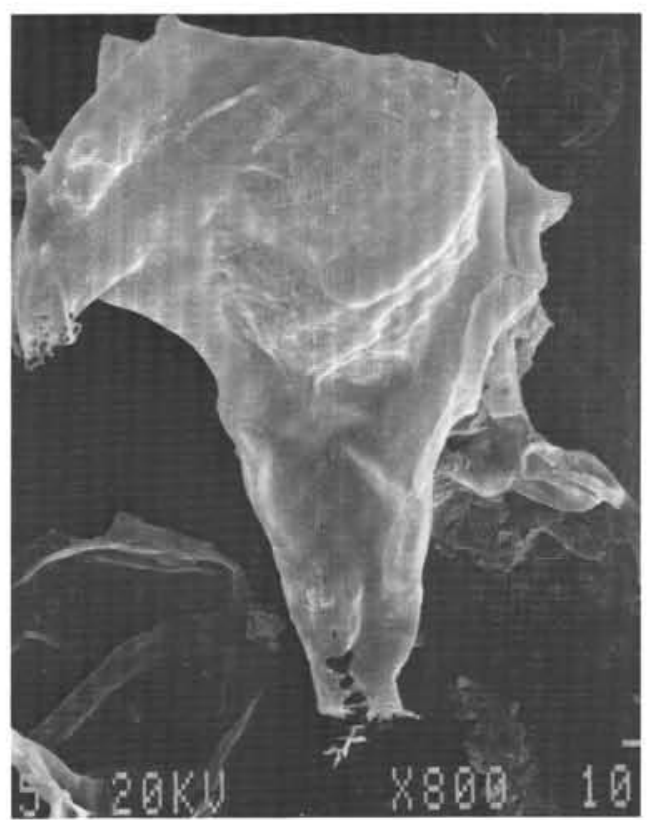

5

Plate 10. SEM photographs. 1. Eurydinium ellipticum n. sp., Sample $120-748 \mathrm{C}-32 \mathrm{R}-1,30-31 \mathrm{~cm}, \times 900.2$. Isabelidinium cretaceum oviforme n. subsp., Sample 120-748C-47R-1, 92-95 cm, $\times 900$. 3. Isabelidinium cretaceum cretaceum, Sample 120-748C-40R-1, 20-23 cm, $\times 700.4$. Odontochitina cribropoda, Sample 120-748C-48R-1, 80-85 cm, $\times 750$. 5. Xenascus ceratioides, Sample $120-748 \mathrm{C}-55 \mathrm{R}-1,42-45 \mathrm{~cm}, \times 800$. 


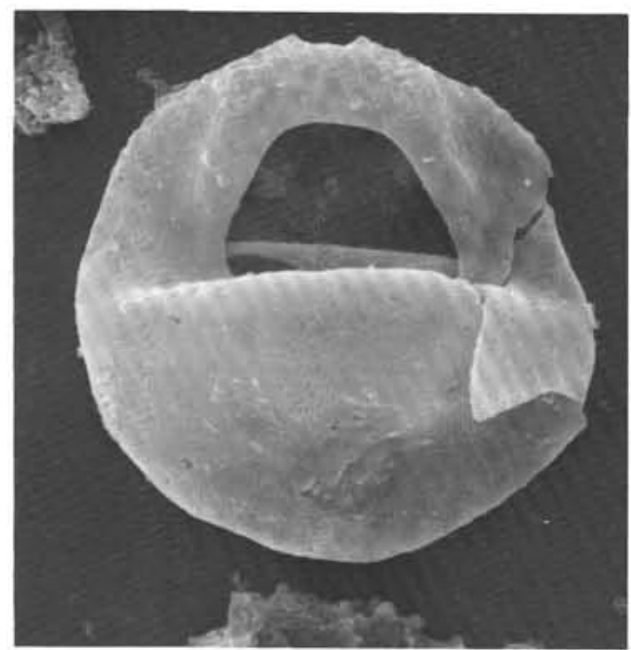

1

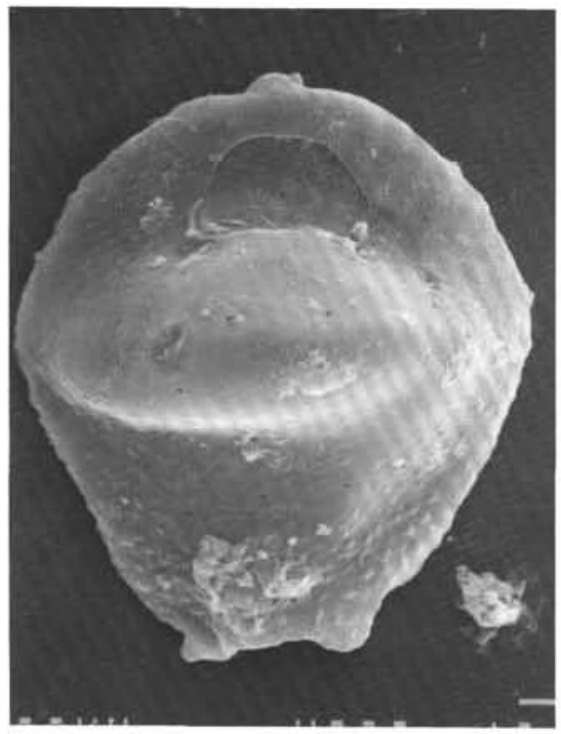

5

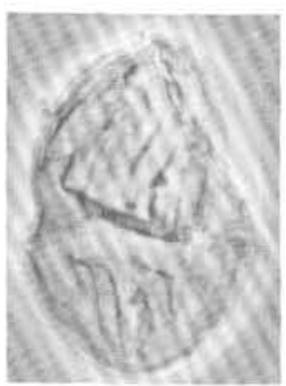

2

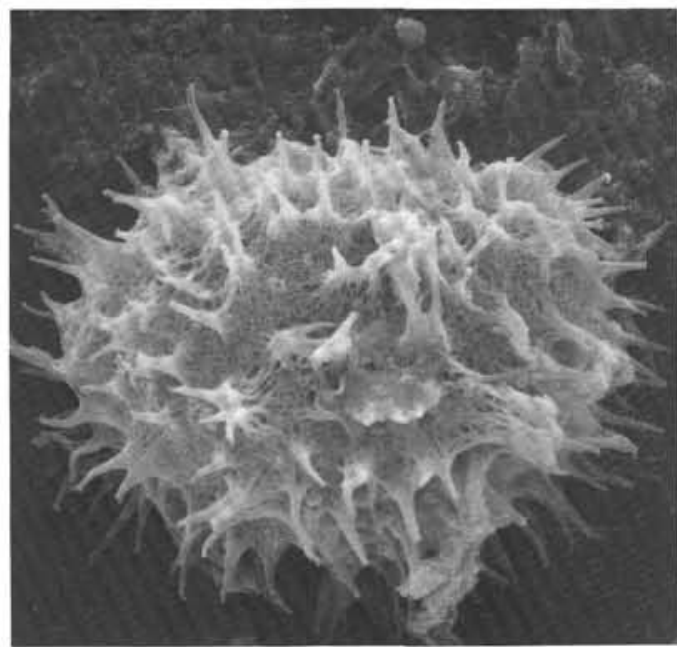

4

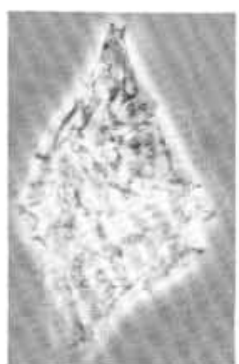

3

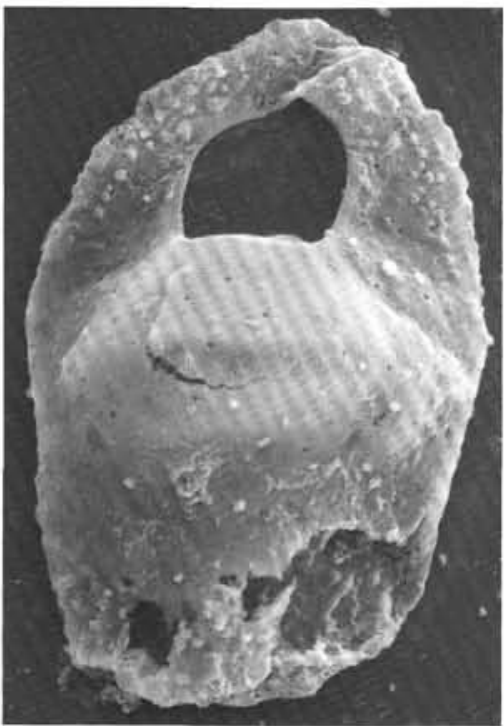

6

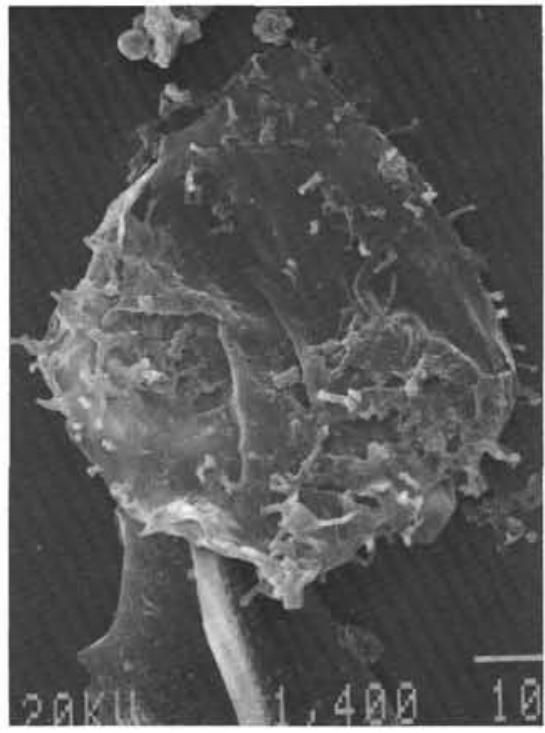

7

Plate 11. SEM photographs, except for Figures 2 and 3. 1. Nelsoniella aceras, Sample 120-748C-44R-1, 126-128 cm, $\times 800.2$. Dinogymnium undulosum, Sample 120-748C-44R-1, 67-69 cm, $\times 550$. 3. Spinidinium? clavus, Sample $120-748 \mathrm{C}-55 \mathrm{R}-1,42-45 \mathrm{~cm}, \times 500.4$. Heterosphaeridium sp., Sample 120-748C-48R-1, 80-85 cm, $\times 900.5$. Isabelidinium cretaceum oviforme $\mathrm{n}$. subsp., Sample 120-748C-48R-1, 80-85 cm, $\times 900$. 6. Isabelidinium cretaceum cretaceum, Sample 120-748C-40R-1, 20-23 cm, $\times 700$. 7. Spinidinium $\mathrm{sp}$., Sample 120-748C-52R-1, 45-47 cm, $\times 1400$. 